\title{
问

\section{Educational and Occupational Aspirations of Rural High School Seniors in the Private and Public Schools in Northwest lowa}

Duane Bajema

Dordt College, duane.bajema@dordt.edu

Follow this and additional works at: https://digitalcollections.dordt.edu/faculty_work

Part of the Agricultural Education Commons

\section{Recommended Citation}

Bajema, D. (1999). Educational and Occupational Aspirations of Rural High School Seniors in the Private and Public Schools in Northwest lowa. Retrieved from https://digitalcollections.dordt.edu/faculty_work/ 201

This Dissertation is brought to you for free and open access by Dordt Digital Collections. It has been accepted for inclusion in Faculty Work Comprehensive List by an authorized administrator of Dordt Digital Collections. For more information, please contact ingrid.mulder@dordt.edu. 


\title{
Educational and Occupational Aspirations of Rural High School Seniors in the Private and Public Schools in Northwest lowa
}

\begin{abstract}
Research has suggested that rural youth have lower educational and occupational aspirations than their nonrural counterparts, and they may experience barriers to educational and occupational attainment. Discrepancies and barriers that may exist have implications for educational policy and educational planning.

Seventeen rural high schools in northwest lowa were examined; thirteen public and four private schools. Rural high school students were studied to examine their perceptions concerning potential educational and occupational barriers. Student characteristics and qualities were examined based on where the student lived and the type of school they attended. Students who had been involved in the agricultural curricula in the high schools were described. Students in private and public schools were studied to examine differences and how the differences might affect community and agricultural development.

Significant differences were found based on where the student lived in their community, in town in a house or apartment or in the country on an acreage, small farm, or large farm. The educational aspirations were very high for all of the students, but the level of educational aspirations were higher for students residing town than the students residing in the country.

Significant differences existed between the students who attended private and public schools. More private school students resided on farms, had more positive perceptions of their communities, and expressed greater intentions of wanting to remain in their communities, but they had lower educational aspirations.
\end{abstract}

Students who took agriculture courses or who participated in FFA had significantly lower aspirations in the level of their educational aspirations and in their intentions to continue their education than their peers.

The study concluded that school planning should recognize that differences in aspirations and perceptions existed between students based on where they lived, and secondly, the students in private schools should be considered as policy and plans are made for community and rural development.

\section{Keywords}

rural youth, high school seniors, occupational aspirations, lowa, educational aspirations, rural development

\section{Disciplines}

Agricultural Education

\section{Comments}

- A dissertation submitted to the graduate faculty in partial fulfillment of the requirements for the degree of DOCTOR OF PHILOSOPHY, Iowa State University

- Dr. W. Wade Miller, Major Professor

- (C) 1999 Duane Harold Bajema 
Educational and occupational aspirations of rural high school seniors in the private and public schools in northwest Iowa

\title{
Duane Harold Bajema
}

\author{
A dissertation submitted to the graduate faculty \\ in partial fulfillment of the requirements for the degree of \\ DOCTOR OF PHILOSOPHY
}

Major: Agricultural Education

Major Professor: W. Wade Miller

Iowa State University

Ames, Iowa

1999 
Graduate College

Iowa State University

This is to certify that the doctoral dissertation of

Duane Harold Bajema

has met the dissertation requirements of Iowa State University

Major Professor

For the Major Program

For the Graduate College 


\section{DEDICATION}

This work is dedicated to my wife Jan, and to my children, Aaron, Aimee, Heather, and Tim, my son-in-law Brian, my grandsons Jacob and Tyler, and to a son-in-law, daughters-in-law, and grandchildren yet to come. You give life richness and blessing as you serve as a daily reminder of God's faithfulness and goodness to me. 
TABLE OF CONTENTS

LIST OF FIGURES $\quad$ vii

LIST OF TABLES $\quad$ viii

ACKNOWLEDGMENTS $\quad$ Xv

CHAPTER I. INTRODUCTION

The Effect of Rural Change on Education $\quad 2$

Student Aspirations in Rural America $\quad 4$

Statement of the Problem $\quad 6$

Purpose and Objectives of the Study

$\begin{array}{ll}\text { Need for the Study } & 10\end{array}$

$\begin{array}{ll}\text { Educational Significance } & 11\end{array}$

$\begin{array}{ll}\text { Operational Definitions } & 11\end{array}$

CHAPTER II. LITERATURE REVIEW 14

$\begin{array}{ll}\text { Early Historical Development } & 14\end{array}$

$\begin{array}{ll}\text { Theories Contributing to Aspirations } & 15\end{array}$

$\begin{array}{ll}\text { Current Aspiration Theory } & 17\end{array}$

$\begin{array}{ll}\text { Aspirations in Education } & 18\end{array}$

Educational Domains $\quad 19$

Behavioral Model $\quad 20$

Aspirations Defined $\quad 20$

Measurement of Aspirations $\quad 22$

Personal and Educational Characteristics $\quad 22$

$\begin{array}{ll}\text { Gender } & 23\end{array}$

Race $\quad 23$

Family Characteristics $\quad 24$

$\begin{array}{ll}\text { Religiosity } & 24\end{array}$

$\begin{array}{ll}\text { Summary } & 24\end{array}$

$\begin{array}{ll}\text { CHAPTER III. METHODOLOGY } & 26\end{array}$

$\begin{array}{ll}\text { Design } & 26\end{array}$

$\begin{array}{ll}\text { Population } & 27\end{array}$

Geographic Information $\quad 28$

Instrumentation $\quad 28$

Population $\quad 30$

Data Collection $\quad 31$

Data Analysis $\quad 32$

Research Questions $\quad 32$

$\begin{array}{ll}\text { CHAPTER IV. FINDINGS } & 34\end{array}$

$\begin{array}{ll}\text { School Information } & 35\end{array}$ 
$\begin{array}{ll}\text { Personal Characteristics } & 37\end{array}$

Gender $\quad 37$

Race $\quad 37$

High school grade point average $\quad 37$

$\begin{array}{ll}\text { Home location } & 38\end{array}$

Religious activity $\quad 41$

Job/work activity $\quad 43$

$\begin{array}{ll}\text { Family Characteristics } & 45\end{array}$

$\begin{array}{ll}\text { Socioeconomic status } & 45\end{array}$

$\begin{array}{ll}\text { Parents' marital status } & 48\end{array}$

Number of siblings $\quad 51$

Parents' educational background $\quad 53$

$\begin{array}{ll}\text { Grandparents } & 60\end{array}$

Parents' farming background $\quad 61$

$\begin{array}{ll}\text { Students' Educational Background } & 62\end{array}$

Agriculture courses taken $\quad 62$

FFA experience $\quad 62$

4-H experience $\quad 66$

Extracurricular activity $\quad 66$

$\begin{array}{ll}\text { Courses taken } & 70\end{array}$

Distance located from school $\quad 73$

$\begin{array}{ll}\text { Student Perceptions and Desires } & 74\end{array}$

$\begin{array}{ll}\text { Student perceptions of community } & 74\end{array}$

$\begin{array}{ll}\text { Community desires } & 77\end{array}$

$\begin{array}{ll}\text { Education perceptions } & 78\end{array}$

Economic perceptions $\quad 81$

Personal time perceptions $\quad 82$

Personal perceptions $\quad 83$

Parental perceptions $\quad 84$

Family perceptions $\quad 85$

$\begin{array}{ll}\text { Religious desires } & 87\end{array}$

$\begin{array}{ll}\text { Future Educational Aspirations } & 88\end{array}$

Educational intent $\quad 88$

Program of study 93

Degree importance $\quad 99$

$\begin{array}{ll}\text { Future Occupational Aspirations } & 100\end{array}$

$\begin{array}{ll}\text { Plans for military } & 100\end{array}$

$\begin{array}{ll}\text { Future location to live } & 100\end{array}$

$\begin{array}{ll}\text { Pursue a career in agriculture } & 103\end{array}$

Potential Barriers to Educational and Occupational Aspirations $\quad 104$

$\begin{array}{ll}\text { Location barriers } & 104\end{array}$

Financial barriers $\quad 105$

$\begin{array}{ll}\text { Personal barriers } & 106\end{array}$

$\begin{array}{ll}\text { External barriers } & 108\end{array}$

$\begin{array}{ll}\text { Educational barriers } & 109\end{array}$

$\begin{array}{ll}\text { Correlations } & 117\end{array}$ 
Objectives $\quad 121$

$\begin{array}{lr}\text { Population } & 122\end{array}$

Research Question $1 \quad 124$

Research Question 2 125

Research Question $3 \quad 126$

Research Question 4 127

Research Question $5 \quad 128$

Research Question 6 130

Research Question 7 132

Research Question 8 133

Research Question 9 133

$\begin{array}{ll}\text { Research Question } 10 & 134\end{array}$

Research Question $11 \quad 136$

Research Question $12 \quad 137$

$\begin{array}{ll}\text { Research Question } 13 & 138\end{array}$

CHAPTER VI. SUMMARY, CONCLUSIONS, IMPLICATIONS, AND RECOMMENDATIONS $\quad 145$

Summary $\quad 145$

Conclusions and Implications $\quad 149$

$\begin{array}{ll}\text { Recommendations } & 157\end{array}$

Recommendations for Further Research 158

$\begin{array}{ll}\text { Implications and Significance to Education } & 158\end{array}$

APPENDIX A. HUMAN SUBJECTS REVIEW COMMITTEE APPROVAL FORM 162

$\begin{array}{ll}\text { APPENDIX B. STUDENT QUESTIONNAIRE } & 166\end{array}$

APPENDIX C. CORRESPONDENCE WITH HIGH SCHOOLS 174

$\begin{array}{ll}\text { APPENDIX D. JOB CLASSIFICATION } & 181\end{array}$

$\begin{array}{ll}\text { APPENDIX E. RURAL DEFINITIONS } & 184\end{array}$

$\begin{array}{lr}\text { APPENDIX F. PROGRAM CODES } & 187\end{array}$

$\begin{array}{ll}\text { REFERENCES } & 193\end{array}$ 
vii

\section{LIST OF FIGURES}

Figure 1. Components of behavioral domain

Figure 2. Grandparents were farmers

Figure 3. Perception of school quality by high school seniors 
viii

\section{LIST OF TABLES}

Table 1. Schools and enrollments in Area Education Agency 4 in northwest Iowa 30

Table 2. School completion rate of questionnaire and class size by school 36

$\begin{array}{lll}\text { Table } & 3 . \text { Gender distribution in schools in AEA } 4 & 37\end{array}$

$\begin{array}{lll}\text { Table 4. Race of students } & 38\end{array}$

Table 5. GPA frequency by location $\quad 39$

$\begin{array}{lll}\text { Table 6. GPA frequency of public and private schools } & 40\end{array}$

Table 7. Frequency distribution of location lived 41

Table 8. Attendance at a church or synagogue for nonrural and rural stridents 42

Table 9. Attendance at a church or synagogue for private and public school students 42

Table 10. Employment level for pay per week of nonrural and rural students 43

Table 11. Employment level for pay per week of private and public school students 44

Table 12. Frequency of reasons why private and public school students worked for pay 44

Table 13. Frequency of reasons why nonrural and rural students work for pay 45

Table 14. Self-reported socioeconomic condition of students' parents of nonrural and rural students

Table 15. Self-reported socioeconomic status of the parents of students from private and public schools

Table 16. Self-reported socioeconomic status of parents of students from different living locations

Table 17. Analysis of variance of socioeconomic perception by where the students lived

Table 18. Means of the students' self-reported socioeconomic status of the parents of nonrural and rural students

Table 19. Marital status of students' parents by where they lived

Table 20. Marital status of students' parents by whether they lived in town or the country 
Table 21. Marital starus of parents of students who attended private and public schools

Table 22. Number of siblings of the students by where they lived

Table 23. Number of siblings of students who lived in town and in the country

Table 24. Number of siblings of students who attended private or public schools

Table 25. Position in the family of students from private and public schools

Table 26. Position in the family of students from nonrural and rural students

Table 27. Frequencies of where the fathers lived and level of education

Table 28. Frequencies of where mothers lived and level of education

Table 29. Fathers' educational level in town and the country

Table 30. Mothers' educational level in town and in the country

Table 31. Educational level of parents of private and public school students

Table 32. Location-where students' fathers were educated for private and public high school students

Table 33. Location where students' fathers were educated for rural and nonrural students

Table 34. Location where students' mothers were educated for private and public high school students

Table 35. Location where students' mothers were educated for rural and nonrural high school students

Table 36. Frequency of students whose grandparents were farmers

Table 37. Frequency of private and public school and rural and nonrural students who were sons or daughters of a farmer

Table 38. Frequencies of students who took agriculture courses

Table 39. Frequency in participation in FFA for private and public school seniors

Table 40. FFA students' level of participation by where they lived

Table 41. FFA participation of nonrural and rural students

Table 42. FFA involvement and aspirations for continued education 
Table 43. Means and standard deviations for continuing their education for students who participated and did not participate in FFA

Table 44. Means and standard deviations for public school students for continuing their education for students who took and did not take agriculture courses and for students who did and did not participate in FFA

Table 45. Participation in 4- $\mathrm{H}$ by private and public school seniors and nonrural and rural seniors

Table 46. Extracurricular activity participation frequencies of nonrural and rural students

Table 47. Extracurricular activity participation frequencies of private and public school students

Table 48. Extracurricular activity participation frequencies of males and females

Table 49. Extracurricular activity participation frequencies of males and females in private schools

Table 50. Extracurricular activity participation frequencies of males and females in public schools

Table 51. Frequencies of specific courses taken by nonrural and rural students

Table 52. Frequencies of specific courses taken by private and public school students

Table 53. Frequencies of students who took a technical drawing or shop class

Table 54. Distance students live from school

Table 55. Student perception of community by location of where they lived

Table 56. Analysis of variance of the community perceptions of students based on where they lived

Table 57. Student perception of community by rural and nonrural students

Table 58. Means and standard deviations of student perception of community of rural and nonrural students

Table 59. Student perception of community by seniors in private and public schools

Table 60. Means and standard deviations of community perception of students in private and public schools 
Table 61. Importance of community desires in adulthood for nonrural and rural students

Table 62. Importance of community desires in adulthood for private and public school studerts

Table 63. Factors that could improve students' future opportunities for nonrural and rural students

Table 64. Factors that could improve students' future opportunities for private and public school students

Table 65. Importance of economic desires in adulthood for nonrural and rural students

Table 66. Importance of economic desires in adulthood for private and public school students

Table 67. Importance of personal time use in adulthood for nonrural and rural students

Table 68. Importance of personal time use in adulthood for private and public school students

Table 69. Personal qualities of students residing in town and the country

Table 70. Personal qualities of students from private and public schools

Table 71. Parental qualities of students living in the country and in town

Table 72. Parental qualities of students living in private and public schools

Table 73. Family concerns affecting a successful adulthood of nonrural and rural students

Table 74. Family concerns affecting a successful adulthood of students from private and public schools

Table 75. Importance of religious desires in adulthood for rural and nonrural students

Table 76. Importance of religious desires in adulthood for private and public school students

Table 77. Educational aspirations to attend a college, trade, or business school

Table 78. Educational aspirations of rural and nonrural residents

Table 79. Frequencies of educational aspirations of private and public school students

Table 80. Means of educational aspirations of private and public school students and rural and nonrural students 
Table 81. Type of education the students planned to pursue after high school

Table 82. Frequencies of males and females for their plans to attend a college, university, or trade school

Table 83. Educational aspirations of those who took agriculture courses and those who did not

Table 84. Means and standard deviations of likelihood of continuing their education for students who took agriculture courses and those who did not

Table 85 . Frequencies of the expected programs of study

Table 86. Frequencies of the expected programs of study of students in private and public schools

Table 87. Frequencies of the expected programs of study of nonrural and rural students

Table 88. Frequencies of the expected programs of study based on gender

Table 89. Importance of obtaining a college degree in adulthood for nonrural and rural students

Table 90. Importance of obtaining a college degree in adulthood for private and public school students

Table 91. Military intentions of the seniors based on where they lived

Table 92. Analysis of variance of students' intentions to enter the military

Table 93. Importance of future living location in adulthood for nonrural and rural students

Table 94. Importance of future living location in adulthood for private and public school students

Table 95. Importance of pursuing an agriculturally related career

Table 96. Perceived rural location barriers to future aspirations for private and public school students

Table 97. Perceived rural location barriers to future aspirations for nonrural and rural students

Table 98. Perceived financial barriers to future educational aspirations for private and public school students 
Table 99. Perceived financial barriers to future educational aspirations for nonrural and rural students

Table 100. Personal attitudes and perceptions that could be barriers to educational and occupational aspirations for private and public school students

Table 101. Personal attitudes and perceptions that could be barriers to educational and occupational aspirations for nonrural and rural students

Table 102. External barriers to educational and occupational aspirations for private and public school students

Table 103. External barriers to educational and occupational aspirations for nonrural and rural students

Table 104. Personal attitudes and perceptions of private and public school students towards their school and their education

Table 105. Personal attitudes and perceptions of nonrural and rural students towards their school and their education

Table 106. Personal attitudes and perceptions of private and public students towards the quality of their education

Table 107. Personal attitudes and perceptions of nonrural and rural students towards the quality of their education

Table 108. Personal attitudes and perceptions of students who have and have not taken agriculture courses towards the quality of their education

Table 109. Occupation desired and occupation that students indicated they would probably have by age 30 for private and public school students

Table 110. Occupation desired and occupation that students indicated they would probably have by age 30 for nonrural and rural students

Table 111. Frequency of where students indicated they will live by age 30 for private and public school students

Table 112. Frequency of where students indicated they will live by age 30 for nonrural and rural students

Table 113. Relationships of selected variables and the qualities that were important to the student's future

Table 114. Relationships of selected variables and the perceptions of school, parents, and selves 
xiv

Table 115. Initial program of study codes

Table 116. Consolidations of program of study 


\section{ACKNOWLEDGMENTS}

I want to express my sincere gratitude to various individuals who have supported and encouraged me in the pursuit of the doctoral degree.

The late Dr. Alan Kahler gave me encouragement and inspired a zeal to proceed. Dr. Wade Miller gave guidance, patience, understanding, perspective, and valuable insight as my major professor and mentor. He supported and encouraged me through times of difficulty as he showed me the way to proceed.

The members of my graduate committee, Dr. Richard I. Carter, Dr. Mark Honeyman, Dr. Paul Lasley, and Dr. M. Peter Hoffman, you challenged me, counseled me with your wisdom, and were influential in my development.

The Agricultural Education and Studies Department faculty members were mentors who encouraged, debated, and provided me a richness, and I am grateful to be able to call them my colleagues. Dr. Schofield gave me help on numerous occasions as I organized and analyzed the data, and he made frustrating situations become manageable.

My fellow graduate students encouraged me, tolerated me, gave me new insights, and provided a wholesome perspective in our work. Their friendship and professional support will hopefully continue to develop.

My colleagues at Dordt College nurtured me and were patient with me as I developed as a faculty member. Their support and encouragement while I took course work and later a leave of absence to study at Iowa State University made what seemed like an insurmountable task achievable.

My wife Jan gave me her patience, love, support, and unfailing encouragement. My accomplishments would be meaningless without her. My children showed great patience and 
understanding as their father took classes at night and during the summer and their support during my time at Iowa State University was kind and demonstrated their love.

The Lord provided me with all of the people mentioned who have been influential in my life. I humbly give all the honor to Him and give thanks for all of the blessings that I have been given. 


\section{CHAPTER I. INTRODUCTION}

Agricultural education has grown and developed in rural America and has contributed to the development of rural communities by addressing the agricultural needs and problems that have arisen in rural communities through education. Agricultural education has addressed rural needs by educating high school students, young farmers, and adult farmers and businessmen by equipping them to solve agricultural problems and improve agricultural efficiencies. Education in agriculture has emanated from the public high schools, earlier as vocational agriculture programs that had an emphasis on equipping high school students to enter agriculture, primarily production agriculture, and more currently, agricultural education prepares students for successful careers and a lifetime of informed choices in the global agriculture, food, fiber, and natural resource systems (NCAE, 1999). In the agricultural education process, agricultural education has addressed agricultural efficiencies. A contribution to agricultural development has been made by the agricultural education offered to high school students and adults in rural communities.

Agriculture has changed and rural America has changed. Technological, political, and economic forces have led to the reduction in the number of farmers and farm size has increased. The demographic changes have affected rural America, but many other factors have also caused rural change and agricultural development. The changes of technology, transportation, communication, industrialization of production and processing, government policy, and education have affected rural America and agricultural development, and the changes will continue as the rural and agricultural economies continue to integrate into a global economy and global community.

Global changes have affected the rural economy, and rural America has responded to the changes as never before. The daily change in the values of various world currencies, weather 
patterns and conditions in various parts of the world, political instability in other countries, changes in government trade policy, futures markets, and the Federal Reserve Board changing the national prime borrowing rate now affect agricultural production and income in a more pronounced way.

Agriculnural education has continued its development by making plans to adapt to the global changes. The Grand Plan for Agricultural Education of Iowa (Governor's Council, 1998) has recognized the new developments and has listed goals for agricultural education, and one of the goals is to "develop and conduct activities that enhance understanding and promote Iowa's role in the global education marketplace" (p. 4). The economy and the culture of rural communities have been adapting to the change, and agricultural education has tried to change as the rural communities have changed. Agricultural education has tried to identify and describe the rural changes in order to better serve the agricultural community.

\section{The Effect of Rural Change on Education}

Rural changes have raised questions concerning the development of the youth in rural America. A national longitudinal study (NCES, 1995) reported the development of educational gaps between urban and rural schools, and researchers have been investigating the condition and development of rural youth. The aciequacy of rural schools is part of a larger unease that rural people, especially rural youth, may be at an educational disadvantage in the changing national and global economy.

The concern for rural schools is not new. There have been many false perceptions about rural America that have been associated with rural education. One false perception has been that many individuals feel that the distinguishing differences between rural and urban have been disappearing as transportation and communication improve. Sociologists John Friedman and John 
Miller (1965) wrote, "From a sociological and indeed economic standpoint what is properly urban and properly rural can no longer be distinguished. The United States has become a thoroughly urban society, perhaps the first such society in history" (p. 313). This ameliorative thinking has led to the argument that all of education has been influenced and defined by an urban/suburban model, and rural educational development emulated an urban model in which educational excellence was defined by educational models that were developed in an urban environment. The experiences in urban education gave credence and impetus to educational reformers who sought to improve rural schools by having them emulate the educational standards of excellence provided by the urban schools. De Antonio (1971) noted that "country schools suffered from an unanticipated handicap, for urban standards were used to judge rural educational progress" (p. 3).

David Tyack (1974) reported that early educational policymakers have pursued an educational system that has promoted an educational system that uses the urban/suburban model for all of education, and by so doing, have failed to recognize urban/suburban/rural differences and have failed to identify the needs and strengths of populations outside the urban/suburban context. Studies have examined rural schools for inequalities in curricular offerings, services, finance, teacher salaries, and student performance when compared to metropolitan schools, but the examination of the instructional frame of a rural school using an urban model has not done justice to rural education. Nachtigal (1982) stated that "much of what is cherished by rural communities happens outside the classroom in so called extracurricular activities. In larger school systems, extracurricular activities are just that-a small part of the local program involving a relatively small percentage of the student body. In a small rural school the rate of participation in extracurricular activities is much higher. The leadership, character building, and socialization skills that come from activity trips, Future Farmers of America judging competition, and other events are in fact an integral part of the school program" (p. 11). The involvement in 
extracurricular activity affects a student's view of community and his/her relationship to the community. Newspapers, newsletters, and radio stations provide many of the students with recognition and attention which generate feelings of self-worth, achievement, importance, and involvement in the community.

\section{Student Aspirations in Rural America}

Recent studies have examined the aspirations of students in the context of rural and urban settings to determine if disadvantages exist. The examination of the educational and occupational aspirations of rural high school students has provided a window that examines the condition of the youth in rural America beyond the typical performance standards used to evaluate students.

The career aspirations developed and possessed by rural secondary students during high school are believed to have a profound effect upon their educational and occupational attainments (McCracken \& Odell, 1988). Aspirations have influenced the learning of students, and the students' aspirations guide them as they prepare for their life choices (Walberg, 1989). Qualglia \& Cobb (1996) have suggested that student aspirations are "the glue that holds the educational process together" (p. 1). It was further stated that aspirations revealed much more than the goals and ambition of a person. Aspirations revealed what persons think and feel about themselves, their school, the role they have in the community, and their feelings about the community where they live. Learning situations that support the acquisition of the skills needed in the world of work will occur if educators develop a more complete understanding of the educational and occupational aspirations and expectations of high school students (Majoribanks, 1984). Learning and the desire to learn have a relationship to the aspirations of the student.

The literature reported that rural youth have lower academic and vocational aspirations than their urban peers (Breen \& Quaglia, 1991; Cobb, McIntire, \& Pratt, 1989; Elliott, 1987; 
McCracken, Barcinas, \& Wims, 1991; Schonert-Reichl, Elliott, \& Bills, 1993). Breen \& Quaglia (1991) have reported that rural students "...aspire to lower levels of higher education, express lower levels of self-confidence in completing the degree requirements, and expect to pursue higher education for a shorter time than urban students" (p. 223). Elliott (1987) suggested that the lower aspirations were partially due to low expectations from the rural parents:

Teachers saw daily evidence of "questionable decisions...made on the basis of fear of the unknown," or an inability to imagine things differently than they were.... Several teachers [also] expressed their frustration of not being able to influence these students' decisions. Instead, the greatest influence came from parents and friends equally unfamiliar and fearful of the world beyond their own rural communities. (p. 5)

Researchers have described various deficiencies in rural schools such as funding, available educational services, and poorer academic performance in the areas of math, science, reading, and history/citizenship/geography which have been implicated to have a detrimental effect on the student aspirations (Sherman, 1992; Stern, 1994; Honeyman et al., 1989; McDermott, 1997).

Conflicting views concerning the aspirations of rural youth have been presented in the literature. Researchers have reported that low aspirations of rural youth are not a problem. Haller and Virkler (1993) reported a slight difference in the aspirations of rural and nonrural youth, and any differences that existed resulted from the lower socioeconomic status of many rural families. A rural population made up of people from a predominantly lower socioeconomic status offered a limited number of examples or models that youth have within their realm of existence. Haller and Virkler (1993) asserted that youth aspire to what they know or can imagine. Due to the lack of role models and examples of vocational diversity, the aspirations of rural youth are limited by the geographic and cultural context of their community.

Rural youth do consider their future, but they experience more conflict and turmoil in their aspirations for education, career, and future location to live and start a career. Hektner (1995) explained that rural youth have more difficulty in the development of their aspirations for the 
future because of the "perceived and actual necessity of leaving their communities in order to pursue their educational and/or career goals" (p. 11).

Others have been advocates to the cause of small and rural schools and have reported that rural and metropolitan schools are quite different culturally, and those cultural differences have not been adequately addressed in the identification of deficiencies and strengths of schools (DeYoung, 1991; Peshkin, 1982; Tyack, 1974). There may be cultural strengths that are inherent in rural schools that have not been identified.

\section{Statement of the Problem}

The educational and occupational aspirations that are developed by rural secondary school students during high school have a significant influence upon their eventual educational and occupational attainment. Research among rural youth on a national level has discovered important differences between the aspirations of the rural high school student and the expectations held by the parents and the school staff (Ley et al., 1996).

The aspirations of high school students in rural areas have been examined to determine the role high schools may have in the preparation of students for life after high school. Rural schools have been examined on a national level, but researchers have been quick to point out that the term "rural schools" has a problem of definition. The rural schools in the United States exhibit a substantial amount of economic and cultural variation on a national basis, and the description and categorization of all rural schools into the category of rural is problematic. Rural schools have been examined on a state level, but states also lack uniformity of definition due to rural cultural and geographical differences that occur within a state. The problems and qualities associated with rural studies may benefit by examining the educational and occupational issues in a localized area. 
The governmental Office of Management and Budget (OMB) has issued classification codes, and the Education Research Service (ERS) has issued classification codes (Johnson codes) which have been used in the literature to define rural. The OMB defined rural as any area outside of a Metropolitan Statistical Area (MSA). A MSA is defined by the OMB to include counties containing a city of fifty thousand or more people and a total area population of one hundred thousand. (See a listing of rural definitions in Appendix E.)

Based on the definition of rural, Iowa is a rural state with a large number of rural schools. Consequently the educational and occupational aspirations of students in the rural schools are significant to educational planning and development in Iowa. Iowa has a classification tied to only certified enrollments and does not reflect the attributes of an urban or rural setting (Alvord, 1999). The categories were:

$<250$ (basically one unit schools-one section each grade)

250-399

400-599

600-999

$1000-2499$

2500-7499

7,500 and above (All districts in this category have multiple high schools.)

The categories of the schools in Iowa were based on the frequency of the distribution of the students only. No provisions in classification have been used to describe the schools.

The literature has reported that cultural differences have occurred in rural schools. The students educated in rural schools have frequently become members of the community that the school served. Graduates have often become the future farmers, businessmen, and labor force for the communities. An examination of the educational and occupational aspirations of young people may reveal helpful information that can be used to better understand the complexities of rural communities. Agricultural education, FFA, and 4-H have been a part of the rural and agricultural 
development process, and the aspirations of students who have been influenced by the local agricultural education activities may provide insights for future planning.

Rural educational development has become a topic of renewed interest and investigation in the midst of demographic trends that have been affecting rural America. The number of farms has been declining and farm size has been increasing which has resulted in a decrease in the number of farmers in the rural areas. The 1992 U.S.D.A's National Agricultural Statistics Service data has shown that compared to the census information of 1982 , there has been a $14 \%$ decrease in the number of farms in the United States. The State of Iowa has experienced a similar decrease of $16 \%$ in the number of farms as farm size increased. The data would indicate that rural areas and subsequently rural schools are in decline. The movement of rural youth from their home communities to urban centers has been described (Donaldson, 1986; Sherman, 1992), and the effect this migration had on the educational system was described by Sher and Tompkins (1977).

Historically various rural areas have undergone deteriorating economic and social conditions which have been compounded by geographic and social isolation as neighbors leave and local communities no longer are the center of commerce and social development. Elliott (1987) reported in her study:

The influences of rural isolation were identified consistently by administrators and teachers alike...as a primary disadvantage in rural schools. For many if not most rural schools...this isolation translates into limited exposure and limited access to needed educational services...; in turn students fear new experiences and they are unwilling to risk exposure to unfamiliar surroundings. (p. 3)

The population trend in the United States has shown an increase in the urban population and a decline in the rural population, and the effects of the trend have been noted extensively in the literature in many fields of study. However, the 1970s showed a turnaround where the rural population was increasing in size more rapidly than the metropolitan areas (Fuguitt, 1985). 
There was a return to the earlier trend of rural population decline in the 1980 s. However, the recent estimates by the U.S. Census have suggested that there has been a significant increase in the nonmetropolitan population since 1990 , largely due to net in-migration (Johnson \& Beale, 1995). The general decline in the number of school-aged children in rural schools has brought attention to issues related to rural education, but as Johnson and Beale have suggested, there may be a turnaround from population migration to the metropolitan area, and either populations may be stabilizing or rural populations may be increasing even though the number of farmers may be declining. Also recent research has indicated that the gap between urban and rural educational achievement has narrowed and is now roughly equal (Gibbs et al., 1998). The educational deficiencies that have existed in the past may also be slowly disappearing, but more information is needed.

The continued attention that has been given to rural education has attempted to illuminate some of the issues associated with rural education. The urban focus in educational research has hindered understanding of the effects of rural schools and communities on the educational and occupational aspirations of rural youth (Schonert-Reichl, Elliott, \& Bills, 1993). Since rural America has been undergoing a substantive agricultural and social change, more research has been needed to examine how the change has affected education in rural schools.

\section{Purpose and Objectives of the Study}

The purpose of the study was to identify and describe the educational, occupational, and personal aspirations to a fulfilling adulthood of rural high school students located in Cherokee, Lyon, O'Brien, Osceola, and Sioux counties which make up the educational district called Area Education Agency 4 (AEA 4) in northwest Iowa and identify disadvantages and barriers that may 
affect their educational and occupational aspirations. The study was designed to add to what has been examined on a national level.

The objectives of the study were to:

1. Describe the personal and educational characteristics of rural high school seniors in AEA 4 in northwest Iowa.

2. Describe the educational, occupational, and personal aspirations to a fulfilling adulthood of rural high school seniors in AEA 4.

3. Identify barriers and disadvantages that may affect educational and occupational aspirations of rural high school seniors.

4. Identify educational aspirations of rural students who reside in town and the country.

5. Describe the characteristics of students who took agriculture courses, were involved in FFA, or participated in 4-H.

6. Describe the characteristics of students of private and public schools who were located in a rural area.

7. Describe the strength of relationship between selected factors of the students.

\section{Need for the Study}

All rural youth deserve equal access to the opportunities of life which are opened up by education and career training, but rural students may face barriers to their development that are unique to the rural school setting. The study of the student aspirations in rural schools may identify the barriers which can lead to their change or removal.

The study of the aspirations of rural high school students in Iowa has been minimal. Social comparison theory has indicated that in groups, there are pressures toward uniformity, and the pressures affect student aspirations. Given this phenomena, it is not unreasonable to assume that 
the aspirations of students are influenced by standards implicitly or explicitly set by peers in school or by the influences and expectations of parents, faculty, and community. Studies have been done nationally and on a state basis, but due to the significant amount of variation that occurs culturally and socially in rural areas between geographic locations in the United States, information on the aspirations of rural youth in a localized area has been limited.

A study of AEA 4 in northwest Iowa, a rural area with all rural schools, an area heavily dependent upon agriculture, and a fairly homogeneous area geographically and culturally would reveal how differences reported on a national basis may be examined in a more localized rural area.

\section{Educational Significance}

The results of this study should describe aspirations, barriers, and demographic characteristics of the students in AEA 4 in northwest Iowa. The study should identify barriers that may exist in the schools in AEA 4 which may restrict the aspirations and eventual careers of rural high school students. The study should provide information to teachers, school administrators, and community members that should assist in the long-term planning and future development of rural schools. The long-term planning could have an impact on education which subsequently affects human and community development. The results may reveal how agricultural education can change to better serve the agricultural education needs in a changing rural America.

\section{Operational Definitions}

Acreage was a house or farm site in the country where the student lived.

Agricultural Education was the education about agriculture that was provided by high school agriculture instructors to high school students and adults in the local communities. 
Area Education Agency 4 (AEA 4) was a specified geographical region of schools that served administrative and service needs of schools that were located in northwest lowa.

Aspiration was the thought or desire to do something or attain a goal in the future.

Gender was the self-reported sex of an individual.

FFA was the abbreviation used for the Future Farmers of America organization.

GPA was the abbreviation of the self-reported cumulative grade point average.

High school was an identifiable school that seniors (grade 12) attended for their education.

High School and Beyond (HSB) was a survey instrument developed by the National Center for Educational Statistics of the U.S. Department of Education.

Indiana Youth Poll was an instrument used to determine the doubts, hopes, and dreams that affect the aspirations students have for their future.

Large farm was a farm of more than 400 acres.

Metropolitan Statistical Area (MSA) was a county which included a city of 50,000 people or more and had a total population of at least 100,000 . The definition is provided by the U.S. Office of Management and Budget which is an application of applied information from the U.S. Census. The definition was modified in 1998 (see Appendix E).

NIRAS was the Northwest Iowa Rural Aspiration Study which was the instrument used for the study.

Nonrural was the location of living in a town in a house or apartment.

Northwest Regional Laboratory (NWRL) was a regional education laboratory funded by the U.S. Department of Education. See http://www.NWREL.ORG for additional information.

Plan for military service was the student reported intentions that entry into the military service would be pursued upon termination or completion of high school.

Primary occupation was the employment that was considered of most importance. 
Program of study was the planned area of study or major that the student expected to study after high school.

Program track was the kind of education or vocation the student planned to pursue after high school.

Race was the self-reported ethnicity of the student.

Rural was living in the country on an acreage, small farm, or large farm.

Rural community was an area that was predominantly agricultural and had towns in the area of less than a population of 10,000 people.

Rural school was a school that served a rural community.

Second job was an additional job performed by one of the parents.

Small farm was a farm of $0-400$ acres.

Town was an incorporated area of homes and businesses of 10,000 people or less. 


\section{CHAPTER II. LITERATURE REVIEW}

\section{Early Historical Development}

The study of educational and occupational aspirations has been an ongoing area of inquiry. The study of aspirations can be traced back to the 1930s, but the theory of aspirations has been part of the learning continuum dating back to the 1600 s if not before.

John Amos Comenius, also known as Jan Amos Komensky, was a bishop in the Protestant Moravian church who was persecuted for his ideas, but despite his persecution, became an intellectual leader in the early 1600 s. His ideas have affected education as we know it today. He promoted a universal system of education for the general population, including women. His ideas were not well received by his peers who were products and proponents of elitism. Education was exclusive and available to the upper class and the aristocracy. He developed a philosophy of pansophism (profession of universal wisdom) which promoted the systematizing of all knowledge and perhaps more importantly, related education to everyday life. He advocated teaching the people in the common language rather than in Latin. Education for the masses evolved slowly but was fundamental to the development of the present system of education where education is accessible to the general population and has been accepted as a right for every U.S. citizen (Comenius, 1910).

John Dewey probably would have found himself in agreement with many of the ideas of Comenius. Dewey was a founder and strong advocate of the philosophy of pragmatism. Most of the philosophical movements developed in Europe, but pragmatism had its roots of development in the United States, and the homegrown philosophy of pragmatism has been a dominant influence in the development of North American society. The emphasis of pragmatism has been the spirit of problem solving. Cox (1996) stated that secular man is a pragmatic who devotes himself to 
tackling specific problems. Dewey developed pragmatism by indicating that motivation and attitude are connected. Dewey (1938) stated that a participant in the learning process deals with two issues: "There is a solicitude, anxiety concerning future consequences, and a tendency to act to assure better, and avert worse, consequences" (p. 146). The two factors identified by Dewey have taken form in aspiration theory.

\section{Theories Contributing to Aspirations}

The concepts of aspirations have been rooted in the theories of motivation and achievement. The investigation of educational and occupational aspirations has been an ongoing area of inquiry since the 1930s. The early research examined aspirations as an expression of the desire to achieve and improve. The construction of aspirations can be traced back to the 1930 s. The "level of aspiration" was noted by Dembo (1976) in an experiment that investigated anger. The subjects of the experiment were subjected to tasks that were very difficult and next to impossible to accomplish. An unplanned outcome of the experiment was that the subjects developed their own intermediary objective when the original goal was unachievable. The intermediary goal represented a step toward the resolution of the problem which Dembo call "momentary level of aspiration" (Gardiner, 1940). Kurt Lewin's work of field theory coincided with Dembo's work. Lewin's work stressed goal directed behavior in group dynamics, and he stressed problem solving by changing group behavior instead of individual behavior (Collier, 1994).

Hoppe conducted research during this time and defined the level of aspiration within the context of a specific task. He defined level of aspiration to be the "totality of...expectations or aspirations for the future performance of achievement of a person, a totality which shifts after each achievement, and which is sometimes vague and sometimes precise" (Hoppe,1976). Hoppe's research introduced the concept that intermediary successes and failures affect the definition of 
eventual aspiration. Hoppe concluded that "the experience of a performance as a success or failure does not depend alone on its objective goodness, but whether the level of aspirations appears to be reached or not reached" (Frank, 1935a).

The subjectivity of measuring aspirations was a concern, and Gardiner (1940) and Frank (1935a) shifted the methodology of aspirations measurement and redefined the construct of aspiration as "the level of future performance in a familiar task which an individual, knowing his level of past performance in that task, explicitly undertakes to reach" (Frank, 1935b). Frank stated that there were two psychological determinants that affected aspirations. The first was the need to avoid failure, and the second was the need to satisfy one's ego and desire to maintain and improve one's social status.

The amount of aspiration research declined in the latter 1940s, and achievement and motivation research predominated. It appeared that McClelland, Atkinson, and Clark (1949) were instrumental in the development of the theory of achievement motivation. Murray's (1938) work on human behavior also indicated that human behavior was goal oriented. The direction and intensity of a person's aspirations were understood to be very important. Collier's (1994) work among underachieving high school students also suggested that achievement motivation was a product of the social environment.

The study of achievement motivation emerged as a dominate theory (Quaglia \& Cobb, 1996). The theory of achievement motivation postulated that people could learn to establish goals, and if goal establishment was a learned activity, it could be acquired. If the trait could be molded and developed because it was acquired, then teachers, peers, parents, and other people who have a relationship with a person would affect achievement motivation. The early research helped us understand the desire of a person to improve. The environmental and social context of the person affected the educational and occupational aspirations of the student. 
Quaglia and Cobb (1996) stated that the "expectations and standards of the group significantly impact the aspirations of its members regardless of their level of achievement motivation. In other words, aspiration level of individual group members is buoyed by the prevailing group standard. Thus, even those with an inner drive to achieve limit their accomplishments to the success level of the group; they fear being ostracized or alienated from the group. This tendency is more pronounced the more isolated the culture" (p. 129). Consequently the aspiration level of youth in rural communities may be more vulnerable to the social influences of a community due to factors of isolation, population size, and community culture. Pressures toward uniformity may be more prevalent in a rural setting than an urban setting, and differences in aspirations may be due to inherent factors present in a rural setting, especially an agricultural community where distance and isolation are important qualities that need to be considered in the educational process (Carlson et al., 1981; Haller \& Virkler,1993; Howell et al., 1996; Reid, 1989).

\section{Current Aspiration Theory}

Collier (1994) related social comparison theory to aspirations. Collier examined the hypotheses of Festinger (1954) that people have a need to evaluate their beliefs and their level of ability. People prefer objective evidence when available, but when unavailable, we tend to compare ourselves to similar groupings of other people with similar beliefs and abilities. Collier (1994) suggested that "[t]he group serves as a powerful anchor that limits the level of aspiration, particularly when the group is cut off from other groups... [p]eople tend to use others who are similar or have similar levels of abilities as a source of social comparison. The threat of ostracism tends to restrict the performance of those with high ability, and performance levels are typically anchored somewhere around the mean" (p. 83). 
Achievement motivation and social comparison theories have been used to develop aspiration theory (Festinger, 1954). Aspirations include inspiration and ambition. Aspirations are related to achievement motivation, but the concepts are different. Achievement motivation is a trait with influence. Achievement motivation describes a relationship between the effects of the environment and the person. Aspiration level is affected by achievement motivation. Aspiration level refers to a specific task, an assessment of the degree or level that a person intends to attain with reference to past performance and the social context (Quaglia \& Cobb, 1996).

\section{Aspirations in Education}

The examination of aspirations in education has become more prevalent. The aspirations of students influence student learning and how they prepare for life's choices (Walberg, 1989). Quaglia (1998) stated that aspirations are "the glue that holds the educational process together" ( $p$. 1). The aspirations reveal how students see themselves and their roles in the school and the community. The more recent literature has shown that aspirations are "qualified by the nature of the activity or goal, by experiences of success and failure, and by social pressures to aim high and do well" (Quaglia \& Cobb, 1996, p.113).

Educational aspirations are important because from an individual perspective, they represent one of the more crucial determinants of social mobility. Where a person functions in a social hierarchy is substantially dependent on his or her adolescent desire for education beyond high school (Haller \& Virkler, 1993).

Education has been a value-laden process which has contributed to the process of aspiration formation. Education should help the participants learn to become more knowledgeable about the cosmos, more sensitive and understanding of their relationship to it, more eager to contribute to the civilizing process, and have the ability to discern opportunities and options that they may 
confront in their day-to-day development. Educational processes should serve purposes beyond the acquisition of specific skills and knowledge. Education should enable the person to better understand who they are and how they can function effectively for their own well-being and for the betterment of society (Kozol, 1984). The educational process is very integral to the formation of educational and occupational aspirations.

\section{Educational Domains}

Learning engages the whole person. Education has examined what have been termed domains or departmentalized areas, and by reducing the process of learning, we have been more able to understand the learning process. Three domains have generally been described and have traditionally served as a framework for describing learning (Bloom et al., 1956).

The cognitive domain described the process of knowing and the development of intellectual abilities and skills. The affective domain described the influences of feelings, values, and beliefs that affect human behavior and development. The psychomotor domain described the development of physical actions, abilities, and skills.

The analysis of learning has also been affected by epistemology which is the study of knowledge. Epistemology "examines the nature of knowledge and the ways in which we obtain it" (Kok, 1998, p. 5). Epistemology has addressed the theory of cognition and has developed as a philosophy that critically investigates the nature, grounds, limits, and criteria, or validity of human knowledge. Human behavior utilizes knowledge of the cognitive domain and is useful in the description of human learning and behavior. 


\section{Behavioral Model}

Hauenstein (1998) has provided a composite model that unifies the traditional taxonomies of the cognitive, affective, and psychomotor domains into a conceptual framework called the behavioral domain by slightly modifying the original taxonomies. The behavioral model has been espoused as a more complete descriptor of human learning and subsequent human behavior.

Figure 1 shows the unified model proposed by Hauenstein. Hauenstein's model effectively linked the cognitive, psychomotor, and affective domains into a behavioral model that adds the concept of aspirations to the understanding of the student. Hauenstein stated that aspirations combine behaving, synthesis, and mastery as a form of behavior. Students move from past performance to aspire to future performance as they develop mastery. The model depicts the person's aspirations at the upper levels in each of the domains which illustrates the potential importance of examining the aspiration levels of the students. Aspirations affect learning and behavior and are illustrative of how the individual views him or herself in the present and how the student may be preparing for the future. Once the aspirations are determined, barriers to the aspirations can be examined to determine what factors may be present that inhibit human development in the family, school, and community. Socioeconomic factors, religion, ethnicity, and geographic location may present barriers as they affect student development in varying degrees.

\section{Aspirations Defined}

The definition of aspirations has undergone development and refinement. Social comparison theory described the need and the pressure to assess beliefs and abilities which develops uniformity in a group (Festinger, 1954). Achievement motivation theory described a conscious 


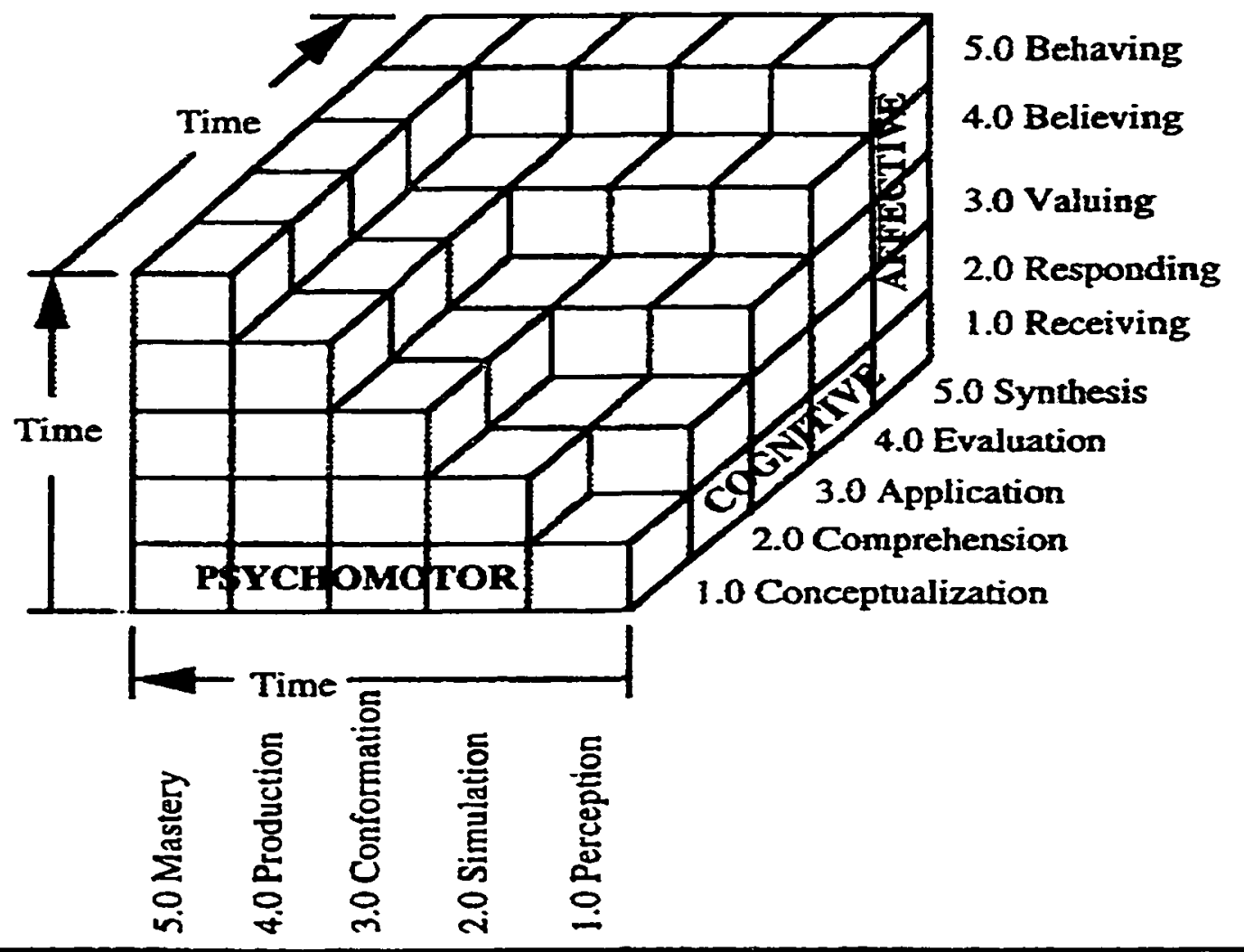

BEHAVIORAL DOMAIN (Composite)

1.0 Acquisition: combines receiving, conceptualization, perception

2.0 Assimilation: combines responding, comprehension, simulation

3.0 Adaptation: combines valuing, application, conformation

4.0 Performance: combines believing, evaluation, production

5.0 Aspiration: combines behaving, synthesis, mastery

Figure 1. Components of behavioral domain (Hauenstein, 1998, p. 9)

desire to perform well and reach high standards of excellence (McClelland, 1961). The definition of aspirations developed from the theories to mean a "student's ability to identify and set goals for the future while being inspired in the present to work toward those goals" (Qualglia \& Cobb, 1996, p. 130). 


\section{Measurement of Aspirations}

Educational and occupational aspirations were most frequently measured with open-ended questions (Majoribanks, 1984; McNair \& Brow, 1983; Ohlendorf \& Rafferty, 1982). Responses were requested for such questions as: What job do you want to have when you are thirty years old? Responses to these questions were scored or categorized using an index such as Duncan's (1961) Socioeconomic Index (SED) or Ohlendorf and Rafferty (1982) recorded occupational aspirations using the Bureau of Census occupational groupings to develop their own modified categories.

Educational aspirations were measured in similar ways and scales were used to present their responses (Marini \& Greenberger, 1978). The scales measured levels of education expected, and the scales have been used to provide categories for educational attainment. The Standard Occupational Classification has been a common classification system which has been provided and used by the Bureau of Labor Statistics (1998).

\section{Personal and Educational Characteristics}

The literature reported studies that considered gender, race, family factors, participation in extracurricular activities, and geographic location, high school program of study, and high school achievement. Personal and educational characteristics represent crucial determinants of social mobility. Where one functions in a communal setting is dependent on the adolescent's desires for education beyond high school and the occupational ramifications of fulfilling those desires (Alexander, Eckland, \& Griffin, 1975; Hurn, 1993; Sewell \& Hauser, 1976). 


\section{Gender}

The literature reported that many of the theoretical models of status attainment were based on male data only. Researchers in the latter 1970s and early 1980s stressed the importance of studying the differences between the educational and occupational aspirations of males and females because of a previous male bias in the literature (Falk \& Salter, 1978; Dunne, Elliott, \& Carlsen, 1981). Dunne, Elliott, \& Carlson (1981) reported that rural women tended to aspire to female stereotyped occupations. Females tended to have significantly higher occupational aspirations than the males studied (Ohlendorf \& Rafferty, 1982; Dunn, Elliott, \& Carlsen (1981). Males aspired and expected higher levels of educational attainment than females (Marini \& Greenberger, 1978).

\section{Race}

Curry and Picou (1971) reported that black high school seniors whose fathers had not completed high school had higher occupational aspirations than white high school seniors whose fathers had the same level of education. However, the study reported that black high school seniors had lower levels of occupational aspirations than white senior high school students of parents who had graduated from high school. Much of the literature related to the study of race and educational and occupational aspirations of rural students was studied in the Southern states (Lee, 1994). McNair and Brown (1983) reported that black students and white students had virtually the same occupational aspirations. The srudies indicated that race was not a major determinant of educational and occupational aspirations of rural students. 


\section{Family Characteristics}

"The family into which a man is born exerts a significant influence on the occupational life, ascribing a status to him at birth that influences his chances for achieving any other status later in his career" (Blau \& Duncan, 1967, p. 295). The family factors of educational level of parents, socioeconomic status, family size, and occupation have been shown to have a significant effect on the educational and occupational aspirations of adolescent family members (Powers, 1974; DeBoard, Griffin, \& Clark, 1977; Falk \& Salter, 1978; Haller \& Virkler, 1993). The literature reported that career choices were affected by the size of the family and the position of the siblings (Powers, 1974). Older children had higher educational and occupational aspirations.

\section{Religiosity}

Differences in religiosity were noted between rural and nonrural people (Rogers, Burdge, Korsching, \& Donnermeyer, 1988) which suggested that differences in formative experiences affected educational and occupational aspirations. De Jong (1984) noted substantive differences on differing dimensions of religiosity in rural areas.

\section{Summary}

The review of literature of the educational and occupational aspirations of high school students provided an overview of the historical development of aspiration research and the supporting theories of aspiration research. Current aspiration theory was discussed and was applied to the process of education. Educational theories were examined to provide a connection to aspiration development in rural high school students.

Aspirations were important because they were significant factors that were indicative of a student's eventual attainment in society (Majoribanks, 1984). Aspirations influenced the learning 
of students (Walberg, 1989), and student aspirations gave a more comprehensive understanding of student learning and behavior (Quaglia \& Cobb, 1996; Hauenstein, 1998).

The aspirations of rural youth have been a concern because various researchers have reported lower academic and occupational aspirations than their urban peers (Breen \& Quaglia, 1991; Cobb, McIntire, \& Pratt, 1989; Elliott, 1987, McCracken, Barcinas, \& Wims, 1991; Schoenert-Reichl, Elliott, \& Bills, 1993). Rural students have been described as disadvantaged because of the disadvantages reported in the rural schools.

Studies of the educational and occupational aspirations of rural high school students focused on personal and educational characteristics, socioeconomic status, parental influence, religious influence, and student perceptions. The literature reported that rural youth struggle more than urban youth about leaving their community.

The review of literature revealed that some work was done in Iowa (Schoenert, Elliott, \& Bills, 1993), and they reported rural youth from farming families had more success than rural youth from nonfarming families because of their access to social ties and experiences from growing up in a farming family. Rural farm youth in comparison to nonfarm youth reported higher levels of extracurricular participation, leadership roles, and rural parental attachment. Farm youth also experienced greater academic success than nonfarm youth. 


\section{CHAPTER III. METHODOLOGY}

\section{Design}

A census study was developed to include an entire population of high school seniors in the specified geographic location called Area Education Agency 4 (AEA 4) located in northwest Iowa. The census study was used to measure tangible elements such as location and student demographics as well as the intangible elements of aspirations, perceptions, and opinions. A generalizable sampling design was considered but would have necessitated sampling nearly ail of the students in the senior class in the smaller schools and only a sampling of the students in the larger schools. Secondly, random sampling techniques would have been difficult to efficiently and effectively administer in the individual schools. The census approach was selected instead of a sampling procedure so that the results could be used by the individual schools for their assessment process which they requested. Under the described circumstances, a census approach was selected as the most appropriate and efficient design.

The seniors of the thirteen public and the four private schools in AEA 4 were asked to answer questions on a questionnaire. The principals or their designates in each of the high schools were asked to administer the questionnaires.

The descriptive study described the incidence and distribution of demographic information and educational variables within AEA 4. The study was intended to examine a specific population at a particular point in time. The study employed descriptive research and statistical methods associated with descriptive research. Descriptive research studies are designed to obtain information about the current status of a phenomenon as it exists at the time of the study (Ary et al., 1990). Significant differences were set a priori at alpha $=.05$. 
The study was designed to control four possible errors associated with survey research:

1. Coverage error was controlled by designing the sample frame to include all the seniors in the participating schools.

2. Measurement error was controlled by selecting questions from previously tested instruments that had validity and high reliability, and the final instrument was tested for validity and reliability.

3. Sampling error was controlled by conducting a census study of all the seniors in a controlled situation under the supervision of the high school principals.

4. Nonresponse error was controlled by asking the principals to administer the instrument during school hours as an activity during the school day.

\section{Population}

The population of AEA 4 was selected because all of the schools were classified as rural schools, the area had a strong agricultural history, many of the schools had agricultural education programs, there were a number of private schools in the area, the area was uniform geographically, and the administration of the schools expressed an interest, willingness to cooperate, and a need for the study.

For heuristic purposes, the study examined the population of high school seniors in a rural agricultural area to describe the students' educational and occupational aspirations and the expectations. The high school seniors were studied in the spring semester and were in a good position to provide information about their future educational and occupational aspirations. 


\section{Geographic Information}

Northwest Iowa has been a significant agricultural area in Iowa as well as the United States. Sioux County ranked third and Plymouth County ranked fifth in the United States for hogs and pigs sold in the United States on a county by county basis. O'Brien County and Plymouth County ranked fourteenth and twenty-second respectively according to the 1992 USDA Agricultural Census.

The January 1, 1997 Census of All Cattle in Iowa Counties based on extrapolations and analysis of the 1992 Census of Agriculture showed Sioux County ranked first in Iowa for grain fed cattle marketed and Lyon County ranked fifth on a county basis. Sioux County ranked number one in Iowa in total farm receipts per county (USDA, 1992).

Three meat processing plants operated in the northwest Iowa area. Major processing facilities existed in the larger cities of Sioux Falls, South Dakota, and Sioux City, Iowa.

The area was very much affected by agriculture and the developments that have occurred in agriculture. The schools existed in a region heavily impacted by the activities of agriculture, and many of the schools had strong agriculture programs. Twelve of the thirteen public schools offered agriculture and FFA in their curriculum and two schools (West Lyon and SibleyOcheydan) had two teachers dedicated to their agricultural instruction program.

\section{Instrumentation}

A survey instrument was designed by adapting survey instruments used by the Northwest Regional Laboratory (NWRL) in their 1996 Youth Aspiration Study, an aspiration study instrument used by the National Center for Student Aspirations located at the University of Maine, the High School and Beyond (HSB) instrument, and the instrument used by the Indiana Youth Poll (TYP). The NWRL instruments were designed to study teachers, students, and parents. 
The NWRL instruments were developed by using selected items from the HSB instruments and the IYP. The HSB was a longitudinal instrument used by the National Center for Educational Statistics of the U.S. Department of Education. The HSB instruments have extensively examined parents' educational background, type of employment, and economic status. The IYP was designed and used primarily to discover the doubts, hopes, and dreams that affect the aspirations students have for the future. All instruments were examined and used in the development of the Northwest Iowa Rural Aspiration Study (NIRAS) instrument (See Appendix B). The NIRAS instrument was developed primarily from the NWRL Youth Aspiration Study instrument because the instruments used previously had a high reliability (.90), and many of the questions were appropriate for the hypotheses of the study.

The NIRAS instrument included questions concerning geographic location, parents' education level, socioeconomic status, parental influence, and religious influence. Students were asked about their backgrounds, their community and school perceptions, and their selfperceptions. Questions were included to determine their future educational and occupational aspirations, and they were asked to respond to potential barriers to their aspirations as they perceived them. Questions were asked about their involvement in agriculture in their rural communities.

Content validity of the instruments was established by a panel of graduate students in the Department of Agricultural Education and Studies at Iowa State University. The NIRAS instrument was pilot tested by a panel of individuals who had recently graduated from high schools from AEA 4 and who now attend Iowa State University. They were not part of the sample. The wording of the instrument was changed to improve clarity. 


\section{Population}

The schools in the AEA 4 district were selected. Four private and thirteen public schools participated in the study. Table 1 shows the seventeen schools that made up AEA 4 district in Iowa. All of the schools in AEA participated in the study. There were 798 testable seniors in the public schools and 253 testable seniors in the private schools, a total of 1,051 seniors.

Table 1. Schools and enrollments in Area Education Agency 4 in northwest Iowa

\begin{tabular}{|c|c|c|c|}
\hline School name & County & $9-12$ & Seniors \\
\hline \multicolumn{4}{|l|}{ Public schools } \\
\hline Boyden-Hull & Sioux & 237 & 27 \\
\hline Central Lyon & Lyon & 196 & 45 \\
\hline George-Little Rock & Lyon & 115 & 39 \\
\hline Hartley-Melvin-Sanborn & Osceola & 290 & 61 \\
\hline Marcus-Meriden-Cleghorn & Cherokee & 213 & 48 \\
\hline MOC-Floyd Valley & Sioux & 447 & 83 \\
\hline Rock Valley & Sioux & 229 & 40 \\
\hline Sheldon & O'Brien & 399 & 97 \\
\hline Sibley-Ocheydan & Osceola & 331 & 73 \\
\hline Sioux Center & Sioux & 303 & 89 \\
\hline South O'Brien & O'Brien & 297 & 66 \\
\hline West Lyon & Lyon & 306 & 79 \\
\hline West Sioux & Sioux & 270 & 51 \\
\hline \multicolumn{4}{|l|}{ Private } \\
\hline Hull Western Christian & Sioux & 438 & 115 \\
\hline Netherlands Reformed & Sioux & 103 & 28 \\
\hline Orange City Unity Christian & Sioux & 383 & 89 \\
\hline Spalding Catholic & Sioux & 95 & 21 \\
\hline Total & & 4,652 & 1,051 \\
\hline
\end{tabular}




\section{Data Collection}

The director of AEA 4, Dr. Gary Hayden, was consulted during the development of the study, and he gave endorsement and support for its implementation. The AEA 4 mail van was used to distribute the questionnaires to the schools, and the mail van was used to return the questionnaires to AEA 4 for retrieval by the researcher.

The principals were asked to participate in the study through personal visits, phone calls, and letters (Appendix C). All the principals agreed to administer the instrument in their respective schools, and upon completion of the questionnaires, the principals returned them to AEA 4 via the mail van. They completed agreement forms (Appendix C) which indicated their willingness to cooperate. The instruments were administered by the principal or their designate in all the private and public schools in AEA 4.

The students provided demographic data and completed 100 questions on an optically scanned bubble answer sheet. They answered eight additional questions by writing answers to questions about parental occupations, future program of study, church affiliation, and future occupational aspirations.

Data were collected on individual schools. No individual student names were requested, and the students remained anonymous in the data collection.

The questionnaires were distributed, administered, and completed by the high schools between March 17, 1999 and April 30, 1999. Phone calls were periodically made to the principals to ascertain the status of the study at each of the schools. All of the schools administered the questionnaires with minimal difficulty. The major obstacle the principals encountered was finding an appropriate time to administer the instrument that would be convenient, efficient, and the greatest number of students possible would be present. 


\section{Data Analysis}

The data were inputted into the Statistical Package for Social Sciences (SPSS) ${ }^{\circ}$, and the handwritten answers were coded and inpurted manually into data sets. The Standard Occupational Classification of the Bureau of Labor Statistics (Appendix D) was used to code the responses given by the students about the occupations of their parents and the occupations they wanted to have after high school. Frequency distributions of the responses were conducted before and after the editing process to control errors during editing.

The computer bubble answer sheets were scanned by an optical reader at the Test and Evaluation Service of Iowa State University. The scanning process revealed improperly completed bubble sheets. Some students used ink instead of number two pencil and there were some improper erasures of answers which caused improper scoring. Corrections were made where appropriate.

\section{Research Questions}

The following research questions were developed to direct the study. Statistical analyses were done to test the questions. The research questions were the following:

1. There will be no difference in the frequency distribution for college, university, trade, or business school aspirations of nonrural students and rural students.

2. There will be no difference in the frequency distribution for college aspirations of students who take agriculture courses and those who do not.

3. There will be no difference in the frequency distribution for personal qualities of rural students who live in the country and those who live in town.

4. There will be no difference in the frequency distribution for family concerns of rural students who live in the country and those who live in town. 
5. There will be no difference in the frequency distribution for a successful adulthood of rural students who live in the country and those who live in town.

6. There will be no difference in the frequency distribution for the educational levels of the fathers and mothers of the rural students who live in town and those who live in the country.

7. There will be no difference in the frequency distribution for program track among those rural students who live in the country and those who live in town.

8. There will be no difference in the frequency distribution for grade point average of those who live in the country and those who live in town.

9. There will be no difference in the frequency distribution for those students who plan to obtain additional education of those rural students who live in the country and those who live in town.

10. There will be no difference in the frequency distribution for the socioeconomic status of parents of rural students who live in the country and those who live in town.

11. There will be no difference in the frequency distribution for community perceptions of those rural students who live in the country and those who live in town.

12. There will be no difference in the frequency distribution for work status of those rural students who live in the country and those who live in town.

13. There will be no difference in the aspirations between students who attend private schools and those who attend public schools. 


\section{CHAPTER IV. FINDINGS}

The purpose of this study was to identify the educational and occupational aspirations and potential barriers to the aspirations of high school seniors in AEA 4 located in northwest Iowa. The schools were located in a rural area where production agriculture in both crops and livestock were prominent in the region.

All of the schools were classified as rural schools. The AEA 4 also included four private schools. All of the schools in AEA 4 participated in the study. The study was designed to investigate the following characteristics:

I. Antecedents

A. School information

B. Personal characteristics

1. Gender

2. Race

3. High school grade point average

4. Home location

5. Religious activity

6. Job/work activity

C. Family characteristics

1. Socioeconomic status

2. Parents' marital status

3. Number and position of siblings

4. Parents' educational background

5. Grandparents' farming history

6. Parents' farming background

II. Students' educational background

A. Agricultural experience

1. Agriculture courses taken

2. FFA experience

3. 4-H experience

B. Extracurricular activity

C. Courses taken

D. Distance located from school

III. Student perceptions/desires

A. Community desires

1. Perceptions

2. Desires

B. Education 

C. Economic
D. Personal
1. Time
2. Personal
E. Parental
F. Family
G. Religious desires

IV. Future educational aspirations
A. Kind and amount
B. Intent
C. Program of study
D. Degree importance
E. Agricultural students

V. Future occupational aspirations
A. Plans for the military
B. Occupation desired/expected
C. Future location to live
D. Pursue career in agriculture

VI. Potential barriers to educational and occupational aspirations
A. Location
B. Financial
C. Personal qualities
D. External factors
E. Educational

VII. Correlations

\section{School Information}

The completion rate for the study is shown in Table 2. Even though the questionnaire was administered during the school day, seniors were absent due to illness, excused school activities, or unexcused absences. The principals of the cooperating schools were unable or unwilling to administer the questionnaire a second time to those students who were absent because of the additional time required to maintain attendance records for the questionnaire's completion, and secondly, find an appropriate and available time in the school day to administer the questionnaire to those specific individuals who were absent during the initial administration of the questionnaire. The questionnaire was completed by $81 \%$ of the 1,051 seniors in AEA 4 . The participation rate of the seniors in each school ranged from $69 \%$ to $100 \%$. The largest school in 
AEA 4 was Hull Western Christian, a private school, and the smallest school was Spalding Catholic, a private school. The average size of the senior class of all the schools was 62 students. The average size of the senior class in private schools was 63 students, and the average size of the senior class in the public schools was 61 students.

Table 2. School completion rate of questionnaire and class size by school

\begin{tabular}{|c|c|c|c|c|c|}
\hline \multirow[b]{2}{*}{ School name } & \multicolumn{5}{|c|}{ Seniors } \\
\hline & $\begin{array}{l}\text { Class } \\
\text { size }\end{array}$ & $\begin{array}{c}\text { Mean } \\
\text { class } \\
\text { size }\end{array}$ & Participants & $\begin{array}{c}\text { Mean } \\
\text { participation }\end{array}$ & $\begin{array}{c}\text { Percent } \\
\text { completion }\end{array}$ \\
\hline \multicolumn{6}{|l|}{ Public schools } \\
\hline Boyden-Hull & 27 & & 25 & & 92 \\
\hline Central Lyon & 45 & & 45 & & 100 \\
\hline George-Little Rock & 39 & & 35 & & 90 \\
\hline Hartley-Melvin-Sanborn & 61 & & 55 & & 92 \\
\hline Marcus-Meriden-Cleghorn & 48 & & 40 & & 83 \\
\hline MOC-Floyd Valley & 83 & & 68 & & 83 \\
\hline Rock Valley & 40 & & 30 & & 75 \\
\hline Sheldon & 97 & & 80 & & 82 \\
\hline Sibley-Ocheydan & 73 & & 57 & & 78 \\
\hline Sioux Center & 89 & & 61 & & 69 \\
\hline South O'Brien & 66 & & 51 & & 77 \\
\hline West Lyon & 79 & & 65 & & 82 \\
\hline West Sioux & 51 & & 43 & & 84 \\
\hline Subtotal & $\overline{798}$ & 61 & $\overline{655}$ & 50 & 82 \\
\hline \multicolumn{6}{|l|}{ Private } \\
\hline Hull Western Christian & 115 & & 85 & & 74 \\
\hline Netherlands Reformed & 28 & & 27 & & 96 \\
\hline Orange City Unity Christian & 89 & & 69 & & 77 \\
\hline Spalding Catholic & 21 & & 17 & & 81 \\
\hline Subtotal & $\overline{253}$ & 63 & $\overline{198}$ & 50 & 78 \\
\hline Total & 1,051 & 62 & 853 & & 81 \\
\hline
\end{tabular}




\section{Personal Characteristics}

\section{Gender}

Table 3 describes the gender distribution of all the schools and the gender distribution in the private and public schools in AEA 4. The gender of the senior students was almost an equal distribution of sex. Males constituted $52.4 \%$ and females $47.2 \%$. There were minor differences between the private and the public schools. The private schools had a percentage of $51 \%$ male and $49 \%$ female and the public schools had a percentage of $52.8 \%$ male and $46.7 \%$ female.

Table 3. Gender distribution in schools in AEA 4

\begin{tabular}{|c|c|c|c|c|c|c|c|}
\hline \multirow[b]{2}{*}{ Schools } & \multicolumn{2}{|c|}{ Male } & \multicolumn{2}{|c|}{ Female } & \multicolumn{2}{|c|}{ Missing } & \multirow[b]{2}{*}{ Total } \\
\hline & freq. & $\%$ & freg. & $\%$ & freq. & $\%$ & \\
\hline Public & 346 & 52.8 & 306 & 46.7 & 3 & 0.5 & 655 \\
\hline Private & 101 & 51.0 & 95 & 49.0 & 0 & 0.0 & 198 \\
\hline Totals & 447 & 52.4 & 403 & 47.2 & 3 & 0.4 & 853 \\
\hline
\end{tabular}

Race

Table 4 shows the race frequencies in the schools. Overwhelmingly Caucasians predominated in the schools with little difference between the private and public schools. The seniors in the schools in northwest lowa were predominately white Caucasian.

\section{High school grade point average}

Table 5 shows the frequencies and percentage distribution of the students' self-reported GPA's by where the students lived. The students who lived on small farms reported the greatest 
Table 4. Race of students

\begin{tabular}{|c|c|c|c|c|}
\hline \multirow[b]{2}{*}{ Schools } & \multicolumn{2}{|c|}{ Private } & \multicolumn{2}{|c|}{ Public } \\
\hline & $\underline{f}$ & $\%$ & $\underline{f}$ & $\%$ \\
\hline White Caucasian & 196 & 99.0 & 633 & 96.8 \\
\hline Hispanic/Latino & 1 & 0.5 & 4 & .6 \\
\hline Black or African American & 1 & 0.5 & 0 & .0 \\
\hline American Indian & 0 & 0.0 & 4 & .6 \\
\hline Oriental or Asian American & 0 & 0.0 & 5 & .8 \\
\hline Exchange student & 0 & 0.0 & 5 & .8 \\
\hline Other & 0 & 0.0 & 3 & .5 \\
\hline Missing & 0 & 0.0 & 1 & .1 \\
\hline Total & 198 & & 655 & \\
\hline
\end{tabular}

percentage of the GPA range of $3.5-4.0$ of $39.7 \%$, followed by $32.8 \%$ for students living on large farms and $30.9 \%$ for the students living on acreages. The students who lived in the country reported higher GPA's than the students who lived in town. The mean GPA was calculated by multiplying the midpoint of the GPA range of each category by the number of students. The value of 1.99 was used for the " $\geq 1.99 "$ category. The total was divided by the total frequency less the students who reported that they did not know their GPA.

Table 6 shows the frequencies and percentage distribution of the students' self-reported GPA's for the private and the public schools. The students in private schools had higher selfreported GPA's than the students from the public schools.

\section{Home location}

Table 7 shows the frequency distribution of where the seniors lived. The percentage of seniors from private schools who lived in the country on farms or acreages was greater compared 
Table 5. GPA frequency by location

\begin{tabular}{|c|c|c|c|c|c|c|c|c|c|c|c|c|c|c|}
\hline \multirow[b]{2}{*}{ Location } & \multirow[b]{2}{*}{ Mean } & \multicolumn{2}{|c|}{$3.5-4.0$} & \multicolumn{2}{|c|}{$3.0-3.49$} & \multicolumn{2}{|c|}{$2.5-2.99$} & \multicolumn{2}{|c|}{$2.0-2.49$} & \multicolumn{2}{|c|}{21.99} & \multicolumn{2}{|c|}{ Don't know } & \multirow[b]{2}{*}{ Total } \\
\hline & & $\underline{f}$ & $\%$ & $\underline{\mathbf{f}}$ & $\%$ & $\underline{f}$ & $\%$ & $\underline{f}$ & $\%$ & $\underline{f}$ & $\%$ & $\underline{f}$ & $\%$ & \\
\hline House in town & 3.12 & 137 & 29.0 & 156 & 33.0 & 107 & 22.6 & 51 & 10.8 & 18 & 3.8 & 4 & 0.8 & 473 \\
\hline Apartment in town & 3.05 & 9 & 21.4 & 12 & 28.6 & 15 & 35.7 & 5 & 11.9 & 0 & 0.0 & 1 & 2.4 & 42 \\
\hline Acreage & 3.11 & 43 & 30.9 & 37 & 26.6 & 34 & 24.5 & 17 & 12.2 & 5 & 3.6 & 3 & 2.2 & 139 \\
\hline Small farm & 3.21 & 48 & 39.7 & 34 & 28.1 & 23 & 19.0 & 13 & 10.7 & 1 & 0.8 & 1 & 0.8 & 121 \\
\hline Large farm & 3.20 & 22 & 32.8 & 26 & 38.8 & 9 & 13.4 & 6 & 9.0 & 3 & 4.5 & 1 & 1.5 & 67 \\
\hline Missing & & & & & & & & & & & & & & 11 \\
\hline Total & & 259 & 30.8 & 265 & 31.5 & 188 & 22.3 & 92 & 10.9 & 27 & 3.2 & 10 & 1.2 & 853 \\
\hline
\end{tabular}


Table 6. GPA frequency of public and private schools

\begin{tabular}{|c|c|c|c|c|c|c|c|c|c|c|c|c|c|c|}
\hline \multirow[b]{2}{*}{ Schools } & \multirow[b]{2}{*}{ Mean } & \multicolumn{2}{|c|}{$3.5-4.0$} & \multicolumn{2}{|c|}{$3.0-3.49$} & \multicolumn{2}{|c|}{$2.5-2.99$} & \multicolumn{2}{|c|}{$2.0-2.49$} & \multicolumn{2}{|c|}{$\geq 1.99$} & \multicolumn{2}{|c|}{ Don't know } & \multirow[b]{2}{*}{ Total } \\
\hline & & $\underline{f}$ & $\%$ & $\underline{f}$ & $\%$ & $\underline{\mathbf{f}}$ & $\%$ & $\underline{f}$ & $\%$ & $\underline{f}$ & $\%$ & $\underline{f}$ & $\%$ & \\
\hline Private & 3.19 & 64 & 32.7 & 73 & 37.2 & 34 & 17.3 & 17 & 8.7 & 7 & 3.6 & 1 & 0.5 & 196 \\
\hline Public & 2.52 & 196 & 30.2 & 192 & 29.6 & 154 & 23.8 & 76 & 11.7 & 20 & 3.1 & 9 & 1.4 & 648 \\
\hline Missing & & & & & & & & & & & & & & 9 \\
\hline Total & & 260 & 30.8 & 265 & 31.4 & 188 & 22.3 & 93 & 11.0 & 27 & 3.2 & 10 & 1.2 & 853 \\
\hline
\end{tabular}


Table 7. Frequency distribution of location lived

\begin{tabular}{|c|c|c|c|c|c|c|}
\hline \multirow[b]{2}{*}{ Location } & \multicolumn{2}{|c|}{ Public } & \multicolumn{2}{|c|}{ Private } & \multicolumn{2}{|c|}{ Total } \\
\hline & $\overline{\mathrm{f}}$ & $\overline{\%}$ & $\underline{\mathbf{f}}$ & $\%$ & $\underline{\underline{f}}$ & $\%$ \\
\hline House in town & 404 & 61.9 & 86 & 43.4 & 490 & 57.4 \\
\hline Apartment in town & 7 & 1.1 & 1 & 0.5 & 8 & 1.0 \\
\hline Acreage & 94 & 14.4 & 53 & 26.8 & 147 & 17.2 \\
\hline Small farm ( $<400$ acres) & 92 & 14.1 & 40 & 20.2 & 132 & 15.5 \\
\hline Large farm ( $>400$ acres) & 56 & 8.6 & 18 & 9.1 & 74 & 8.7 \\
\hline Missing & 2 & 0.1 & 0 & 0.0 & 2 & 0.2 \\
\hline Total & 653 & 76.7 & 198 & 23.3 & 853 & \\
\hline
\end{tabular}

to the seniors from public schools (56.1 vs. 37.1$)$. There were 498 nonrural students $(58.4 \%)$ and 353 rural students ( $41.4 \%$ ) in the study. Two-tenths of a percent of the students did not answer the question.

\section{Religious activity}

Table 8 shows the frequency of activity in a church or synagogue for rural and nonrural students. A greater percentage of nonrural students (7.6\%) did not participate in religious activities compared to students living in the country (3.6\%). Sixty-one and three-tenths percent of the students living in town attended services weekly and $73.6 \%$ of the rural students attended services weekly. Eighty-seven and six-tenths percent of the rural and $78.6 \%$ of the nonrural students attended services at least once per month. Nonrural students were different than rural students because a greater percentage of nonrural students did not participate in religious activities, and more rural students participated in religious activities on a weekly basis than nonrural students. Rural students attended church more frequently than nonrural students. 
Table 8. Attendance at a church or synagogue for nonrural and rural students

Religious activity

$\frac{\text { Nonrural }}{\text { f* }} \% \quad \frac{\text { Rural** }}{\%} \quad \%$

Do not participate in religious activities

Attend services or participate in activities weekly

41

7.9

12

3.6

Attend services once or twice per month

318

61.3

242

73.6

Attend services one to eleven times per year

90

17.3

14.0

54

10.4

46

25

7.6

I only attend weddings, funerals, and anniversaries

at religious facilities

16

3.1

4

1.2

Table 9 shows the frequency of activity in a church or synagogue for private and public school students. The private school students attended services on a weekly basis more frequently than the public school students $(85.4 \%$ and $60 \%)$. Ninety-five percent of the private school students attended services at least once per month compared to $77.9 \%$ of the students in public schools. There was a significant difference between private and public school students in church attendance.

Table 9. Attendance at a church or synagogue for private and public school students

Religious activity

$\frac{\text { Private*** }}{\mathrm{f}}$
$\frac{\text { Public*** }}{\text { f. }}$

Do not participate in religious activities Attend services or participate in activities weekly Attend services once or twice per month Attend services one to eleven times per year I only attend weddings, funerals, and anniversaries at religious facilities

$\begin{array}{rrrr}5 & 2.5 & 48 & 7.4 \\ 169 & 85.4 & 392 & 60.0 \\ 19 & 9.6 & 117 & 17.9 \\ 4 & 2.0 & 77 & 11.8 \\ 1 & 0.5 & 19 & 2.9\end{array}$

$$
{ }^{* * *} \mathrm{p}<.001 ; \chi^{2}(1, \mathrm{~N}, 851)=46.02
$$




\section{Job/work activity}

Table 10 shows the extent of employment of nonrural and rural students. The percentage of rural students working for pay was greater than the nonrural student in the "11-20 hours" category and the " $>20$ hours" category. When the two categories are combined, $54.6 \%$ of the nonrural students and $61.2 \%$ of the rural students worked eleven or more hours per week. The chi-square analysis indicated that the rural and nonrural groups were significantly different in the number of hours worked per week that the students worked.

Table 10. Employment level for pay per week of nonrural and rural students

\begin{tabular}{|c|c|c|c|c|}
\hline \multirow[b]{2}{*}{ Employment level } & \multicolumn{2}{|c|}{ Nonrural ${ }^{* * *}$} & \multicolumn{2}{|c|}{ Rural*** } \\
\hline & $\underline{f}$ & $\%$ & $\underline{f}$ & $\%$ \\
\hline 0 hours & 80 & 15.4 & 46 & 14.2 \\
\hline $0-10$ hours & 155 & 29.9 & 80 & 24.6 \\
\hline 11-20 hours & 185 & 35.7 & 122 & 37.5 \\
\hline$>20$ hours & 98 & 18.9 & 77 & 23.7 \\
\hline
\end{tabular}

$$
* * * \underline{p}<.001 ; \chi^{2}(1, N, 849)=42.97
$$

Table 11 shows the extent of employment for private and public school students. Fifty-six and three-tenths percent of the public school students worked eleven or more hours per week compared to $60.9 \%$ of the private school students. A greater percentage (21.6\%) of the public school students compared to private school students (18.8\%) worked more than twenty hours per week. A chi-square analysis showed a significant difference between private and public school students. 
Table 11. Employment level for pay per week of private and public school students

\begin{tabular}{|c|c|c|c|c|}
\hline \multirow[b]{2}{*}{ Employment level } & \multicolumn{2}{|c|}{ Private*** } & \multicolumn{2}{|c|}{ Public*** } \\
\hline & $\underline{f}$ & $\%$ & $\underline{f}$ & $\%$ \\
\hline 0 hours & 16 & 8.1 & 110 & 16.9 \\
\hline $0-10$ hours & 61 & 31.0 & 174 & 26.8 \\
\hline 11-20 hours & 83 & 42.1 & 225 & 34.7 \\
\hline$>20$ hours & 37 & 18.8 & 140 & 21.6 \\
\hline
\end{tabular}

${ }^{* * *} \underline{\mathrm{L}}<.001 ; \chi^{2}(1, \mathrm{~N}, 846)=11.72$

Table 12 shows the reasons students in private and public schools selected for why they worked. A higher percentage (41.4\%) of the private school students selected "I need money for my future plans (college, business, car, etc.)" compared to the public school students (30.8\%). The public school students selected "I need money for my transportation expenses" as the major reason they worked (33\%). A chi-square analysis showed a significant difference between the public and private school students concerning their reasons for working.

Table 12. Frequency of reasons why private and public school students worked for pay

Reasons for work

$\frac{\text { Private* }}{\mathrm{f}} \quad \frac{\text { Public* }}{\mathrm{f}}$

I do not work.

Parents encourage me to work.

I need the money for food, clothing, and other necessities.

I need the money for my transportation expenses.

I need money for future plans (college, business, car).

\section{2}

11

33

56

79
6.3

5.8

96

43

14.7

6.6

$\begin{array}{lll}17.3 & 97 & 14.7\end{array}$

$\begin{array}{lll}29.3 & 215 & 33.0\end{array}$

$\begin{array}{llll}9 & 41.4 & 201 & 30.8\end{array}$

$$
{ }^{*} \underline{D}<.001 ; \chi^{2}(1, N, 853)=244.84
$$


Table 13 shows the reasons for working that were reported by nonrural and rural students. A greater percentage of rural students (37\%) worked because they needed the money for their future plans compared to the nonrural students (30.8\%). The differences were significantly different for rural and nonrural students.

Table 13. Frequency of reasons why nonrural and rural students work for pay

Reasons for work

$\frac{\text { Nonrural*** }}{\underline{f}} \quad \frac{\text { Rural*** }}{\text { f }}$

I do not work. 70

13.6

38

Parents encourage me to work.

I need the money for food, clothing, and other necessities.

I need the money for my transportation expenses.

I need money for future plans (college, business, car).

\section{8}

172

15.1

33.3

52

16.0

159

30.8

120

$* * * \mathrm{p}<.001 ; \chi^{2}(1, \mathrm{~N}, 849)=42.97$

\section{Family Characteristics}

\section{Socioeconomic status}

Table 14 shows the self-reported socioeconomic status of nonrural and rural students. A greater percentage of the rural students reported themselves to "Have a below average income" or "An average income" than nonrural students.

The "Struggle from month to month," "Below average income" and "Average income" categories were combined for the nonrural and rural students. Seventy-nine percent of the nonrural students described their parents as average or below, and $86.5 \%$ of the rural students described themselves as average or below. 
Table 14. Self-reported socioeconomic condition of students' parents of nonrural and rural students

Socioeconomic condition

$\frac{\text { Nonrural** }}{\mathrm{f}} \quad \frac{\text { Rural** }}{\mathrm{f}}$

Struggle from month to month

$\begin{array}{lll}29 & 5.6 & 17\end{array}$

5.2

Below average income

Average income

47

9.1

38

333

64.3

227

Above average income

Comfortable living

81

15.6

33

11.7

81

5.4

11

69.6

10.1

$\begin{array}{llll}28 & 5.4 & 11 & 3.4\end{array}$

$$
{ }^{* *} \mathrm{p}<.01 ; \chi^{2}(1, \mathrm{~N}, 847)=42.97
$$

Table 15 shows the self-reported socioeconomic status of private and public school students. There were no statistically significant differences between the private and public school students.

Table 16 shows the self-reported socioeconomic status of the students according to where they lived. When the three categories, "Struggle from month to month," "Below average

Table 15. Self-reported socioeconomic status of the parents of students from private and public schools

Socioeconomic condition

$\frac{\text { Private }}{\mathrm{f}} \quad \frac{\text { Public }}{\mathrm{f}}$

Struggle from month to month

$\begin{array}{rrrr}8 & 4.1 & 38 & 5.8 \\ 19 & 9.6 & 66 & 10.2 \\ 140 & 71.7 & 422 & 64.9 \\ 24 & 12.2 & 91 & 14.0 \\ 6 & 3.0 & 33 & 5.1\end{array}$

Below average income

Average income

Above average income

Comfortable living

6

3.0

5.8

64.9

14.0

5.1 
income," and "Average income," were combined, $92.4 \%$ of the small farm students were included compared to $87.5 \%$ for students living in apartments, $84.9 \%$ of the students living on a large farm, $82.7 \%$ of students living on an acreage, and $78 \%$ for students living in town.

"Average income," "Above average income," and "Live comfortably" were combined, and the percentage for the students living in town was $85.6 \%$, sudents in an apartment $62.5 \%$, students on an acreage $82.7 \%$, students living on a small farm $84.8 \%$, and students living on a large farm $82.2 \%$.

Table 16. Self-reported socioeconomic status of parents of students from different living locations

\begin{tabular}{|c|c|c|c|c|c|c|c|c|c|c|}
\hline \multirow{2}{*}{$\begin{array}{l}\text { Socioeconomic } \\
\text { condition }\end{array}$} & \multicolumn{2}{|c|}{$\begin{array}{l}\text { House in } \\
\text { town }\end{array}$} & \multicolumn{2}{|c|}{$\begin{array}{c}\text { Apart- } \\
\text { ment }\end{array}$} & \multicolumn{2}{|c|}{ Acreage } & \multicolumn{2}{|c|}{$\begin{array}{c}\text { Small } \\
\text { farm }\end{array}$} & \multicolumn{2}{|c|}{$\begin{array}{l}\text { Large } \\
\text { farm }\end{array}$} \\
\hline & $\underline{f}$ & $\%$ & $\underline{f}$ & $\%$ & $\underline{\mathrm{f}}$ & $\%$ & $\underline{f}$ & $\%$ & $\underline{\mathbf{f}}$ & $\%$ \\
\hline \multicolumn{11}{|l|}{ Struggle from month } \\
\hline to month & 25 & 5.1 & 3 & 37.5 & 6 & 4.1 & 9 & 6.8 & 3 & 4.1 \\
\hline Below average income & 45 & 9.2 & 0 & 0.0 & 19 & 13.1 & 11 & 8.3 & 10 & 13.7 \\
\hline Average income & 311 & 63.7 & 4 & 50.0 & 95 & 65.5 & 102 & 77.3 & 49 & 67.1 \\
\hline Above average income & 79 & 16.2 & 1 & 12.5 & 18 & 12.4 & 6 & 4.5 & 11 & 15.1 \\
\hline Live comfortably & 28 & 5.7 & 0 & 0.0 & 7 & 4.8 & 4 & 3.0 & 0 & 0.0 \\
\hline
\end{tabular}

The socioeconomic responses were treated as interval data and the means were analyzed with analysis of variance. Table 17 shows the results. The apartment dwellers had the lowest selfreported socioeconomic level (2.36) followed by the students who lived on a small farm (2.89) followed by the students who lived on large farms (2.93). Table 17 shows that the socioeconomic status of students who lived in an aparment, small farm, and large farm were significantly different using the least significant difference post hoc test. 
Table 17. Analysis of variance of socioeconomic perception by where the students lived $(\mathrm{N}=845)^{2}$

\begin{tabular}{|c|c|c|c|}
\hline Location lived & $\mathbf{M}$ & SD & $F^{b}$ \\
\hline House in town & 3.08 & 0.83 & $3.26^{* *}$ \\
\hline Apartment & $2.36^{c}$ & 1.19 & \\
\hline Acreage & 3.01 & 0.79 & \\
\hline Small farm & $2.89^{c}$ & 0.72 & \\
\hline Large farm & $2.93^{c}$ & 0.67 & \\
\hline
\end{tabular}

${ }^{2}$ Scale: $1=$ Disadvantaged financially and struggle from month to month, $2=$ Have a below average income compared to others in the community, $3=$ Have an average income, $4=$ Have an above average income, and $5=$ Live quite comfortably and have many economic advantages that others do not have.

${ }^{b} \mathrm{~F}(4,841) ; \underline{\mathrm{p}}<.01$.

${ }^{c}$ Denotes means significantly different using a least significant difference test.

${ }^{* *} \mathrm{p}<.05$.

Table 18 shows the differences of rural and nonrural students. The nonrural students reported a significantly lower socioeconomic status than the rural students.

\section{Parents' marital status}

Table 19 shows the marital status of the parents of the students according to where they lived. The small farm and large farm categories had the highest percentages of "Married, never been divorced" (90.2\% and $89.2 \%)$ followed by "Acreage" (75.5\%) and "House in town" (75.3\%). The "Married, one or both parents were previously divorced" category and the "Single parent, divorced, never married, widowed, or separated" category were combined and showed that $50 \%$ of apartment dwellers, $21 \%$ of the parents who lived in a house in town, and $19.7 \%$ of the parents who lived on an acreage were included in the combined category. 
Table 18. Means of the students' self-reported socioeconomic status of the parents of nonrural and rural students

\begin{tabular}{lcccc}
\hline Factors & M & SD & N & t \\
\hline Nonrural $^{*}$ & 3.06 & 0.83 & 518 & -2.02 \\
Rural $^{*}$ & 2.95 & 0.75 & 326 & \\
\hline
\end{tabular}

${ }^{2}$ Scale: $1=$ They are disadvantaged financially and struggle from month to month; $2=$ They have a below average income compared to other families in the community; $3=$ They have an average income compared to other families in the community; $4=$ They have an above average income compared to other families in the community; 5=They live comfortably and have many economic advantages that others do not have.

${ }^{*} \mathrm{p}<.05$.

Table 19. Marital status of students' parents by where they lived $(\mathrm{N}=851)$

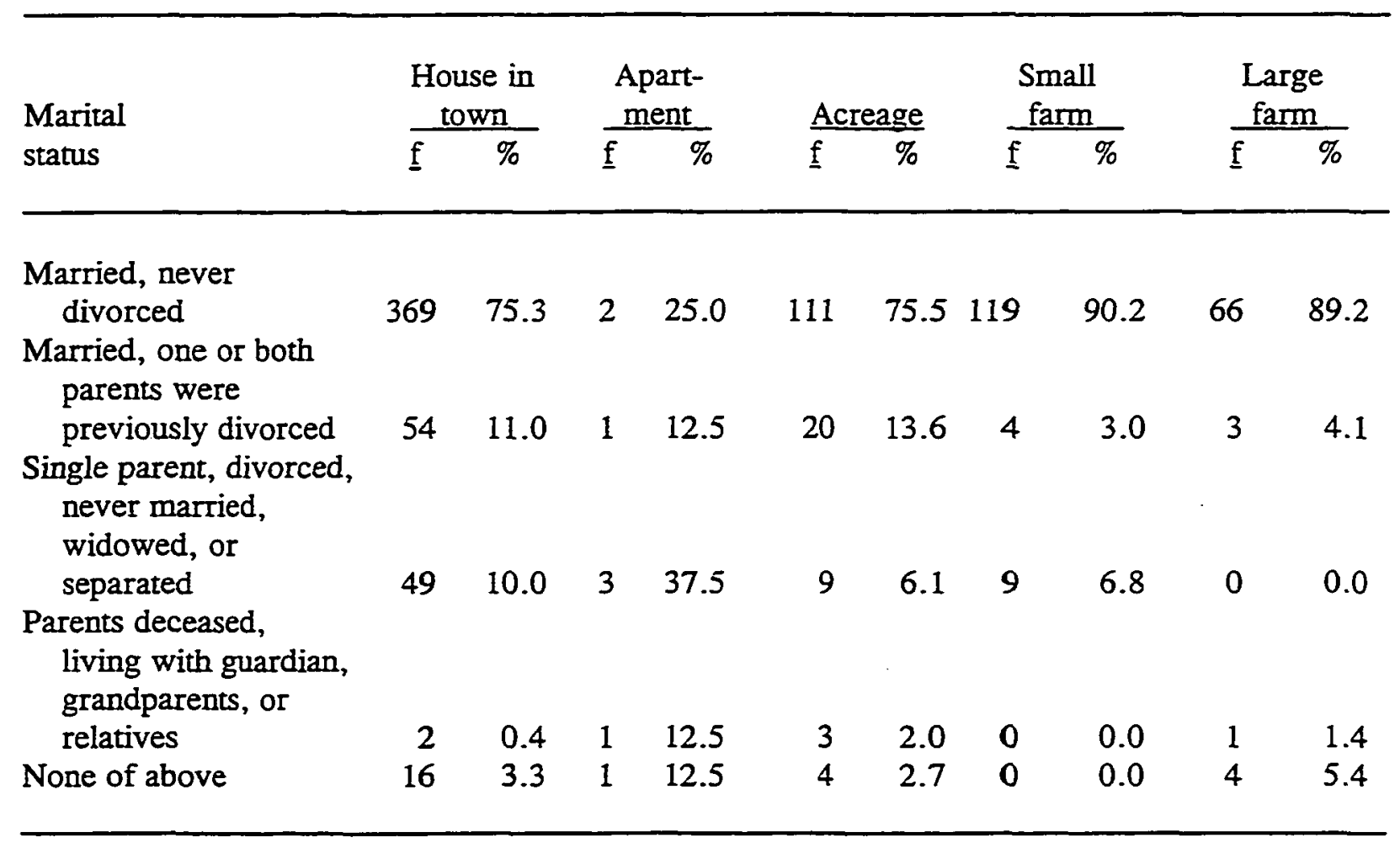


Table 20 shows the marital status of the parents by their living in town or the country (nonrural and rural). Of the 849 students, $8.2 \%$ lived with single parents. A chi-square analysis showed that rural students had a greater percentage of parents who were married and never divorced.

Table 20. Marital status of students' parents by whether they lived in town or the country $(\mathrm{N}=849)$

Single parent, divorced, never married, widowed, or separated

Parents deceased, living with guardian, grandparents, or relatives

None of the above
55

10.6

15

4.6

4

$$
{ }^{* *} \chi^{2}(1, \mathrm{~N}=849)=42.97 ; \mathrm{p}<.01
$$

Table 21 shows the marital status of the parents of students who attended private and public schools. Ninety and four-tenths percent of the students in private schools reported that their parents were married and never divorced compared to $74.8 \%$ of the parents of the students who attended the public schools.

A chi-square analysis showed that private and public students were significantly different. Private school students had a greater percentage of parents who were married and never divorced. 
Table 21. Marital status of parents of students who attended private and public schools $(\mathrm{N}=852)$

Marital status

$\frac{\text { Private }}{\text { f* }} \%$

$\frac{\text { Public** }}{\%}$

Married, never divorced

Married, one or both parents were divorced

$\begin{array}{rrrr}179 & 90.4 & 489 & 74.8 \\ 7 & 3.5 & 75 & 11.5 \\ 7 & 3.5 & 63 & 9.6 \\ & & & \\ 0 & 0.0 & 7 & 1.1 \\ 5 & 2.5 & 20 & 3.1\end{array}$

Single parent, divorced, never married, widowed, or separated

Parents deceased, living with guardian, grandparents, or relatives

None of the above

3.1

$$
* * \chi^{2}(1, N=852)=244.8 ; \mathrm{p}<.01 \text {. }
$$

\section{Number of siblings}

Table 22 shows the number of siblings of the students by where they lived. The students living on small farms had the largest percentage (25\%) of "4 or more siblings," and those students who lived in town had the largest percentage $(3.3 \%)$ of having no siblings.

Table 22. Number of siblings of the students by where they lived

\begin{tabular}{|c|c|c|c|c|c|c|c|c|c|c|c|c|}
\hline \multirow{2}{*}{$\begin{array}{l}\text { No. of } \\
\text { siblings }\end{array}$} & \multicolumn{2}{|c|}{$\begin{array}{l}\text { House in } \\
\text { town }\end{array}$} & \multicolumn{2}{|c|}{$\begin{array}{c}\text { Apart- } \\
\text { ment }\end{array}$} & \multicolumn{2}{|c|}{ Acreage } & \multicolumn{2}{|c|}{$\begin{array}{c}\text { Small } \\
\text { farm }\end{array}$} & & $\begin{array}{c}\text { Large } \\
\text { farm } \\
\end{array}$ & \multicolumn{2}{|c|}{ Total } \\
\hline & $\underline{f}$ & $\%$ & $\underline{\mathbf{f}}$ & $\%$ & & $\%$ & $\underline{f}$ & $\%$ & & $\%$ & $\underline{\mathrm{f}}$ & $\%$ \\
\hline 0 & 16 & 3.3 & 0 & 0.0 & 1 & .7 & 3 & 2.3 & 2 & 2.7 & 22 & 2.6 \\
\hline 1 & 117 & 23.9 & 0 & 0.0 & 24 & 16.3 & 26 & 19.7 & 18 & 24.3 & 185 & 21.7 \\
\hline 2 & 190 & 38.8 & 3 & 37.5 & 48 & 32.7 & 35 & 26.5 & 28 & 37.8 & 304 & 35.7 \\
\hline 3 & 107 & 21.8 & 3 & 37.5 & 45 & 30.6 & 35 & 26.5 & 15 & 20.3 & 205 & 24.1 \\
\hline 4 or & & & & & & & & & & & & \\
\hline more & 60 & 12.2 & 2 & 25.0 & 29 & 19.7 & 33 & 25.0 & 11 & 14.9 & 135 & 15.9 \\
\hline
\end{tabular}


Table 23 shows the number of siblings of the students who resided in town and who resided in the country. The rural sudents had a greater percentage of " 4 or more siblings" than the nonrural students. The category "2 siblings" had the greatest percentage for nonrural (38.3\%) and rural (31.9\%) in their respective groups. When the " 3 siblings" and " 4 or more siblings" were combined, the rural students had a greater percentage $(47.7 \%)$ than the nonrural students (35\%). The differences between nonrural and rural students were significantly different.

Table 23. Number of siblings of students who lived in town and in the country $(N=849)$

\begin{tabular}{|c|c|c|c|c|c|c|}
\hline \multirow{2}{*}{$\begin{array}{l}\text { No. of } \\
\text { siblings }\end{array}$} & \multicolumn{2}{|c|}{ Nonrural** } & \multicolumn{2}{|c|}{ Rural** } & \multicolumn{2}{|c|}{ Total } \\
\hline & $\underline{\mathbf{f}}$ & $\%$ & $\underline{f}$ & $\%$ & $\underline{f}$ & $\%$ \\
\hline 0 & 16 & 3.1 & 6 & 1.8 & 22 & 2.6 \\
\hline 1 & 123 & 23.7 & 61 & 18.5 & 184 & 21.7 \\
\hline 2 & 199 & 38.3 & 105 & 31.9 & 304 & 35.8 \\
\hline 3 & 119 & 22.9 & 85 & 25.8 & 204 & 24.0 \\
\hline 4 or more & 63 & 12.1 & 72 & 21.9 & 135 & 15.9 \\
\hline
\end{tabular}

$* * \chi^{2}(1, N=843)=42.67 ; \mathrm{p}<.01$.

Table 24 shows the number of siblings of the students who attended private and public schools. The students in private schools and public schools reported the " 2 siblings" category as having the greatest percentage ( $29.8 \%$ and $37.6 \%$ ), and if the " 3 siblings" and " 4 or more siblings" groups were combined, the private school students had the greater percentage of 3 or more siblings (55.8\%) compared to the public school students $(35.2 \%)$. The differences were significantly different.

The position in the family of the students is reported in Table 25. The largest percentage of students reported themselves in the "Between" category, which included $44.7 \%$ of the private 
Table 24. Number of siblings of students who attended private or public schools $(N=852)$

No. of siblings

$\frac{\text { Private** }}{\underline{\mathrm{f}}} \% \quad \frac{\text { Public** }}{\underline{\mathrm{f}}} \quad \frac{\text { Total }}{\%} \quad \underline{\underline{\mathrm{f}}} \%$

\begin{tabular}{lrrrrrr}
0 & 2 & 1.0 & 20 & 3.1 & 22 & 2.6 \\
1 & 27 & 13.6 & 158 & 24.2 & 185 & 21.7 \\
2 & 59 & 29.8 & 246 & 37.6 & 305 & 35.8 \\
3 & 56 & 28.3 & 149 & 22.8 & 205 & 24.1 \\
4 or more & 54 & 27.3 & 81 & 12.4 & 135 & 15.8 \\
\hline
\end{tabular}

$* * \chi^{2}(1, \mathrm{~N}=852)=244.8 ; \mathrm{p}<.01$.

Table 25. Position in the family of students from private and public schools

\begin{tabular}{|c|c|c|c|c|c|c|c|c|c|}
\hline & \multicolumn{2}{|c|}{ Only child } & \multicolumn{2}{|c|}{ Oldest } & \multicolumn{2}{|c|}{ Between } & \multicolumn{2}{|c|}{ Youngest } & \multirow[b]{2}{*}{ Total } \\
\hline & $\mathrm{f}$ & $\%$ & $\mathrm{f}$ & $\overline{\%}$ & $f$ & $\%$ & $\mathrm{f}$ & $\%$ & \\
\hline Private & 3 & 1.5 & 52 & 26.4 & 88 & 44.7 & 54 & 27.4 & 197 \\
\hline Public & 22 & 3.4 & 221 & 34.2 & 234 & 36.2 & 170 & 26.3 & 647 \\
\hline
\end{tabular}

school seniors and $36.2 \%$ of the public school seniors ( $44.7 \%$ and $36.2 \%)$. The private school students had greater percentages for "Between" and "Youngest." The level of significance was not considered significant at the 0.06 level.

Table 26 shows the same variables for nonrural and rural students. There were no significant differences between the two groups.

\section{Parents' educational background}

The frequencies of educational levels of attainment of the fathers and mothers of the students are reported in Tables 27 and 28 based on where they lived. Fifty-five and two-tenths 
Table 26. Position in the family of students from nonrural and rural students

\begin{tabular}{|c|c|c|c|c|c|c|c|c|c|}
\hline & \multicolumn{2}{|c|}{ Only child } & \multicolumn{2}{|c|}{ Oldest } & \multicolumn{2}{|c|}{ Between } & \multicolumn{2}{|c|}{ Youngest } & \multirow[b]{2}{*}{ Total } \\
\hline & $\mathrm{f}$ & $\%$ & $\bar{f}$ & $\overline{\%}$ & $\bar{f}$ & $\overline{\%}$ & $\bar{f}$ & $\overline{\%}$ & \\
\hline Nonrural & 16 & 3.1 & 174 & 33.7 & 188 & 36.4 & 139 & 26.9 & 517 \\
\hline Rural & 9 & 2.8 & 97 & 29.9 & 133 & 41.0 & 85 & 26.2 & 324 \\
\hline
\end{tabular}

percent of the fathers and $54 \%$ of the mothers had a level of education of high school or below. The ranking by location combining "Did not graduate" and "High school or GED" showed that $65.9 \%$ of the fathers living on small farms, $63.6 \%$ of the fathers living on large farms, and $59.5 \%$ of the fathers living on acreages had a high school education or less. Of the fathers living in town, $49.6 \%$ of the fathers living in a house in town and $42.9 \%$ of those living in an apartment had a high school education or less.

Table 27. Frequencies of where the fathers lived and level of education

\begin{tabular}{|c|c|c|c|c|c|c|c|c|c|c|c|}
\hline \multirow[b]{2}{*}{ Location } & \multicolumn{2}{|c|}{$\begin{array}{c}\text { Did not } \\
\text { graduate } \\
\text { from H.S. }\end{array}$} & \multicolumn{2}{|c|}{$\begin{array}{l}\text { H.S. } \\
\text { or GED } \\
\text { graduate }\end{array}$} & \multicolumn{2}{|c|}{$\begin{array}{l}\text { Comm. } \\
\text { college, } \\
\text { trade, } \\
\text { technical }\end{array}$} & \multicolumn{2}{|c|}{$\begin{array}{l}\text { 4-year } \\
\text { degree }\end{array}$} & \multicolumn{2}{|c|}{$\begin{array}{l}\text { Beyond } \\
4 \text { years }\end{array}$} & \multirow[b]{2}{*}{ Total } \\
\hline & $\underline{f}$ & $\%$ & $\underline{f}$ & $\%$ & $\underline{f}$ & $\%$ & $\underline{\mathbf{f}}$ & $\%$ & $\underline{f}$ & $\%$ & \\
\hline House in town & 32 & 6.6 & 209 & 43.0 & 113 & 23.3 & 100 & 20.6 & 32 & 6.6 & 486 \\
\hline Apartment & 1 & 14.3 & 2 & 28.6 & 1 & 14.3 & 2 & 28.6 & 1 & 14.3 & 7 \\
\hline Acreage & 14 & 9.5 & 75 & 51.0 & 29 & 19.7 & 21 & 14.3 & 8 & 5.4 & 147 \\
\hline Small farm & 6 & 4.5 & 81 & 61.4 & 28 & 21.2 & 16 & 12.1 & 1 & 0.8 & 132 \\
\hline Large farm & 3 & 4.1 & 44 & 59.5 & 11 & 14.9 & 15 & 20.3 & 1 & 1.4 & 74 \\
\hline Missing & & & & & & & & & & & 7 \\
\hline Total & 56 & 6.6 & 411 & 48.6 & 182 & 21.5 & 154 & 18.2 & 43 & 5.1 & 853 \\
\hline
\end{tabular}


The percentages of the fathers who had a four-year degree were similar for the individuals living in a house in town (20.6\%), apartment (28.6\%), and large farm (20.3\%). The percentages of the father who had a four-year degree were less for those who lived on an acreage (14.3\%) and those who lived on a small farm (12.1\%).

The frequencies of the mothers in Table 28 by location combining "Did not graduate" and "High school or GED" showed $61.4 \%$ of the mothers on small farms, $55.4 \%$ of the mothers living on large farms, and $46.2 \%$ of the mothers living on acreages had a high school education or less. Of the mothers living in town, $57.2 \%$ of the mothers living in an apartment and $53.9 \%$ of the mothers living in houses in town had a high school education or less. The percentage of mothers who had more than a high school education (46.1\%) was higher than the percentage of the fathers $(44.8 \%)$.

Table 28. Frequencies of where mothers lived and level of education

\begin{tabular}{|c|c|c|c|c|c|c|c|c|c|c|c|}
\hline \multirow[b]{2}{*}{ Location } & \multicolumn{2}{|c|}{$\begin{array}{c}\text { Did not } \\
\text { graduate } \\
\text { from H.S }\end{array}$} & \multicolumn{2}{|c|}{$\begin{array}{c}\text { H.S. } \\
\text { or GED } \\
\text { graduate }\end{array}$} & \multicolumn{2}{|c|}{$\begin{array}{l}\text { Comm. } \\
\text { college, } \\
\text { trade, } \\
\text { technical }\end{array}$} & \multicolumn{2}{|c|}{$\begin{array}{l}\text { 4-year } \\
\text { degree }\end{array}$} & \multicolumn{2}{|c|}{$\begin{array}{l}\text { Beyond } \\
4 \text { years }\end{array}$} & \multirow[b]{2}{*}{ Total } \\
\hline & $\underline{f}$ & $\%$ & $\underline{f}$ & $\%$ & $\underline{f}$ & $\%$ & $\underline{f}$ & $\%$ & $\underline{\mathrm{f}}$ & $\%$ & \\
\hline House in town & 31 & 6.3 & 233 & 47.6 & 133 & 27.2 & 76 & 15.5 & 16 & 3.3 & 489 \\
\hline Apartment & 2 & 28.6 & 2 & 28.6 & 0 & 0.0 & 2 & 28.6 & 1 & 14.3 & 7 \\
\hline Acreage & 8 & 5.4 & 60 & 40.8 & 40 & 27.2 & 34 & 23.1 & 5 & 3.4 & 147 \\
\hline Small farm & 3 & 2.3 & 78 & 59.1 & 25 & 18.9 & 21 & 15.9 & 5 & 3.8 & 132 \\
\hline Large farm & 0 & 0.0 & 41 & 55.4 & 15 & 20.3 & 16 & 21.6 & 2 & 2.7 & 74 \\
\hline Missing & & & & & & & & & & & 4 \\
\hline Total & 44 & 5.2 & 414 & 48.8 & 213 & 25.1 & 149 & 17.6 & 29 & 3.4 & 853 \\
\hline
\end{tabular}


Tables 29 and 30 show the fathers' and mothers' educational level based on whether they lived in town or the country. A lesser percentage of the fathers who lived in the country had an education beyond high school (36.1\%) than the fathers who lived in town (50.9\%).

The mothers' educational level between rural residents and nonrural residents is shown in Table 30; $45.6 \%$ of the mothers living in the country had an education beyond high school, and $43.9 \%$ of the mothers living in town had an education beyond high school. The mothers living in the country had more education beyond high school than the fathers living in the country $(45.6 \%$ versus $36.1 \%)$.

Table 31 shows the educational level of the parents of private and public school students. There were no significant differences in educational levels between the fathers of the private and public school students nor between the mothers of private and public school students.

Table 29. Fathers' educational level in town and the country

\begin{tabular}{|c|c|c|c|c|c|c|c|c|c|c|c|}
\hline \multirow[b]{2}{*}{ Location } & \multicolumn{2}{|c|}{$\begin{array}{l}\text { Did not } \\
\text { graduate } \\
\text { from H.S. }\end{array}$} & \multicolumn{2}{|c|}{$\begin{array}{c}\text { H.S. } \\
\text { or GED } \\
\text { graduate } \\
\end{array}$} & \multicolumn{2}{|c|}{$\begin{array}{l}\text { Comm. } \\
\text { college, } \\
\text { trade, } \\
\text { technical }\end{array}$} & \multicolumn{2}{|c|}{$\begin{array}{l}\text { 4-year } \\
\text { degree }\end{array}$} & \multicolumn{2}{|c|}{$\begin{array}{l}\text { Beyond } \\
4 \text { years }\end{array}$} & \multirow[b]{2}{*}{ Total } \\
\hline & $\underline{f}$ & $\%$ & $\underline{\mathbf{f}}$ & $\%$ & $\underline{f}$ & $\%$ & $\underline{f}$ & $\%$ & $\underline{f}$ & $\%$ & \\
\hline Rural*** & 22 & 6.7 & 188 & 57.1 & 61 & 18.5 & 48 & 14.6 & 10 & 3.0 & 329 \\
\hline $\begin{array}{l}\text { Nonrural*** } \\
\text { Missing }\end{array}$ & 36 & 7.0 & 217 & 42.1 & 120 & 23.3 & 107 & 20.8 & 35 & 6.8 & $\begin{array}{r}515 \\
9\end{array}$ \\
\hline Total & 58 & 6.9 & 405 & 48.0 & 181 & 21.4 & 155 & 18.4 & 45 & 5.3 & 853 \\
\hline
\end{tabular}

${ }^{* * *} \chi^{2}(4, N=844)=18.47, \mathrm{p}<.001$ 
Table 30. Mothers' educational level in town and in the country

\begin{tabular}{|c|c|c|c|c|c|c|c|c|c|c|c|}
\hline \multirow[b]{2}{*}{ Location } & \multicolumn{2}{|c|}{$\begin{array}{c}\text { Did not } \\
\text { graduate } \\
\text { from H.S. }\end{array}$} & \multicolumn{2}{|c|}{$\begin{array}{l}\text { H.S. } \\
\text { or GED } \\
\text { graduate }\end{array}$} & \multicolumn{2}{|c|}{$\begin{array}{l}\text { Comm. } \\
\text { college, } \\
\text { trade, } \\
\text { technical }\end{array}$} & \multicolumn{2}{|c|}{$\begin{array}{l}\text { 4-year } \\
\text { degree }\end{array}$} & \multicolumn{2}{|c|}{$\begin{array}{l}\text { Beyond } \\
4 \text { vears }\end{array}$} & \multirow[b]{2}{*}{ Total } \\
\hline & $\underline{f}$ & $\%$ & $\underline{\mathbf{f}}$ & $\%$ & $\underline{\mathrm{f}}$ & $\%$ & $\underline{\underline{f}}$ & $\%$ & $\underline{\mathrm{f}}$ & $\%$ & \\
\hline Rural & 10 & 3.0 & 169 & 51.4 & 74 & 22.5 & 66 & 20.1 & 10 & 3.0 & 329 \\
\hline $\begin{array}{l}\text { Nonrural } \\
\text { Missing }\end{array}$ & 52 & 10.0 & 239 & 46.1 & 133 & 25.7 & 77 & 14.9 & 17 & 3.3 & $\begin{array}{r}518 \\
3\end{array}$ \\
\hline Total & 62 & 7.3 & 408 & 48.2 & 207 & 24.4 & 143 & 16.9 & 27 & 3.2 & 853 \\
\hline
\end{tabular}

Table 31. Educational level of parents of private and public school students

\begin{tabular}{|c|c|c|c|c|c|c|c|c|c|c|}
\hline \multirow{2}{*}{$\begin{array}{l}\text { Level of } \\
\text { education }\end{array}$} & \multicolumn{2}{|c|}{$\begin{array}{c}\text { Did not } \\
\text { graduate } \\
\text { from H.S. }\end{array}$} & \multicolumn{2}{|c|}{$\begin{array}{l}\text { H.S. } \\
\text { or GED } \\
\text { graduate }\end{array}$} & \multicolumn{2}{|c|}{$\begin{array}{l}\text { Comm. } \\
\text { college, } \\
\text { trade, } \\
\text { technical }\end{array}$} & \multicolumn{2}{|c|}{$\begin{array}{l}\text { 4-year } \\
\text { degree }\end{array}$} & \multicolumn{2}{|c|}{$\begin{array}{l}\text { Beyond } \\
4 \text { years }\end{array}$} \\
\hline & $\overline{\mathrm{f}}$ & $\%$ & $\underline{\mathbf{f}}$ & $\%$ & $\overline{\underline{f}}$ & $\overline{\%}$ & $\underline{\mathrm{f}}$ & $\overline{\%}$ & $\underline{\mathrm{f}}$ & $\%$ \\
\hline \multicolumn{11}{|l|}{ Fathers } \\
\hline Private & 13 & 6.6 & 100 & 50.5 & 41 & 20.7 & 33 & 16.7 & 11 & 5.6 \\
\hline Public & 43 & 6.6 & 311 & 47.9 & 142 & 21.9 & 121 & 18.6 & 32 & 4.9 \\
\hline \multicolumn{11}{|l|}{ Mothers } \\
\hline Private & 6 & 3.0 & 101 & 51.0 & 43 & 21.7 & 41 & 20.7 & 7 & 3.5 \\
\hline Public & 38 & 5.8 & 313 & 48.0 & 171 & 26.2 & 108 & 16.6 & 22 & 3.4 \\
\hline
\end{tabular}

Table 32 shows that $38.1 \%$ of the fathers of private school students attended the same high school as their son or daughter, and $29 \%$ of the fathers of public school students attended the same school as their son or daughter. Combining the two categories of "This high school" and "School within 25 miles, " $68.1 \%$ of the fathers of private school students and $58.1 \%$ of the 
Table 32. Location where students' fathers were educated for private and public high school students

\begin{tabular}{|c|c|c|c|c|c|c|c|c|c|c|c|}
\hline & \multicolumn{2}{|c|}{$\begin{array}{c}\text { This } \\
\text { high } \\
\text { school }\end{array}$} & \multicolumn{2}{|c|}{$\begin{array}{r}\text { School } \\
\text { within } \\
25 \text { miles } \\
\end{array}$} & \multicolumn{2}{|c|}{$\begin{array}{r}25-50 \\
\text { miles } \\
\text { away } \\
\end{array}$} & \multicolumn{2}{|c|}{$\begin{array}{c}51-100 \\
\text { miles } \\
\text { away } \\
\end{array}$} & \multicolumn{2}{|c|}{$\begin{array}{c}\text { Over } \\
100 \text { miles } \\
\text { away } \\
\end{array}$} & \multirow[b]{2}{*}{ Total } \\
\hline & $\underline{\mathrm{f}}$ & $\%$ & $\underline{\mathrm{f}}$ & $\%$ & $\underline{\mathbf{f}}$ & $\%$ & $\underline{\mathrm{f}}$ & $\%$ & $\underline{\mathbf{f}}$ & $\%$ & \\
\hline Private** & 75 & 38.1 & 81 & 30.0 & 13 & 6.6 & 8 & 4.1 & 20 & 10.2 & 197 \\
\hline Public** & 188 & 29.0 & 189 & 29.1 & 80 & 12.3 & 58 & 8.9 & 134 & 20.6 & 649 \\
\hline
\end{tabular}

$$
* * \chi^{2}(4, \mathrm{~N}=846)=29.10, \mathrm{p}<.01
$$

fathers of public school students attended their son or daughter's high school or a school within 25 miles.

Table 33 shows that $47.4 \%$ of the fathers of students who lived in the country, and $33.8 \%$ of the fathers of students who lived in town were educated in the same high school as their son or daughter. "This high school" and "School within 25 miles" categories were combined, and $82.5 \%$ of the fathers residing in the country and $61.8 \%$ of the fathers residing in town went to the same high school or a high school within 25 miles of the students' high school as their son or daughter.

Table 33. Location where students' fathers were educated for rural and nonrural students

\begin{tabular}{|c|c|c|c|c|c|c|c|c|c|c|c|}
\hline & \multicolumn{2}{|c|}{$\begin{array}{l}\text { This } \\
\text { high } \\
\text { school }\end{array}$} & \multicolumn{2}{|c|}{$\begin{array}{c}\text { School } \\
\text { within } \\
25 \text { miles } \\
\end{array}$} & \multicolumn{2}{|c|}{$\begin{array}{r}25-50 \\
\text { miles } \\
\text { awav } \\
\end{array}$} & \multicolumn{2}{|c|}{$\begin{array}{c}51-100 \\
\text { miles } \\
\text { away } \\
\end{array}$} & \multicolumn{2}{|c|}{$\begin{array}{c}\text { Over } \\
100 \text { miles } \\
\text { away } \\
\end{array}$} & \multirow[b]{2}{*}{ Total } \\
\hline & $\underline{\underline{f}}$ & $\%$ & $\overline{\mathrm{f}}$ & $\overline{\%}$ & $\overline{\mathbf{f}}$ & $\%$ & $\underline{f}$ & $\%$ & $\overline{\mathrm{f}}$ & $\%$ & \\
\hline Nonrural** & 174 & 33.8 & 144 & 28.0 & 57 & 11.1 & 44 & 8.5 & 96 & 18.6 & 515 \\
\hline Rural** & 154 & 47.4 & 114 & 35.1 & 18 & 5.5 & 8 & 2.5 & 31 & 9.5 & 325 \\
\hline
\end{tabular}

$$
* * \chi^{2}(4, \mathrm{~N}=840)=42.37, \mathrm{p}<.01
$$


Table 34 shows that $38.1 \%$ of the mothers of private school students attended the same high school as their son or daughter, and $29 \%$ of the mothers of public school sudents attended the same school as their son or daughter. Combining the two categories of "This high school" and "School within 25 miles," $79.2 \%$ of the mothers of private school students and $58.1 \%$ of the mothers of public school students attended their son or daughter's high school or a school within 25 miles.

Table 34. Location where students' mothers were educated for private and public high school students

\begin{tabular}{|c|c|c|c|c|c|c|c|c|c|c|c|}
\hline & \multicolumn{2}{|c|}{$\begin{array}{c}\text { This } \\
\text { high } \\
\text { school }\end{array}$} & \multicolumn{2}{|c|}{$\begin{array}{c}\text { School } \\
\text { within } \\
25 \text { miles } \\
\end{array}$} & \multicolumn{2}{|c|}{$\begin{array}{r}25-50 \\
\text { miles } \\
\text { away } \\
\end{array}$} & \multicolumn{2}{|c|}{$\begin{array}{c}51-100 \\
\text { miles } \\
\text { away } \\
\end{array}$} & \multicolumn{2}{|c|}{$\begin{array}{c}\text { Over } \\
100 \text { miles } \\
\text { away } \\
\end{array}$} & \multirow[b]{2}{*}{ Total } \\
\hline & $\overline{\mathbf{f}}$ & $\%$ & $\underline{f}$ & $\%$ & $\underline{f}$ & $\%$ & $\underline{f}$ & $\%$ & $\underline{\mathrm{f}}$ & $\%$ & \\
\hline Private*** & 75 & 38.1 & 81 & 41.1 & 13 & 6.6 & 8 & 4.1 & 20 & 10.2 & 197 \\
\hline Public*** & 188 & 29.0 & 189 & 29.1 & 80 & 12.3 & 58 & 8.9 & 134 & 20.6 & 649 \\
\hline
\end{tabular}

$* * * \chi^{2}(4, \mathrm{~N}=846)=29.10, \mathrm{p}<.001$

Table 35 shows that $30.8 \%$ of mothers living in the country and $31.5 \%$ of the mothers living in town attended the same high school as their son or daughter. The largest percentage difference between the mothers living in the country and the mothers living in town is the "51-100 miles away" variable (4\% of the mothers living in the country and $10.3 \%$ of the mothers living in town). 
Table 35. Location where students' mothers were educated for rural and nonrural high school students

\begin{tabular}{|c|c|c|c|c|c|c|c|c|c|c|c|}
\hline & \multicolumn{2}{|c|}{$\begin{array}{l}\text { This } \\
\text { high } \\
\text { school }\end{array}$} & \multicolumn{2}{|c|}{$\begin{array}{c}\text { School } \\
\text { within } \\
25 \text { miles } \\
\end{array}$} & \multicolumn{2}{|c|}{$\begin{array}{r}25-50 \\
\text { miles } \\
\text { away } \\
\end{array}$} & \multicolumn{2}{|c|}{$\begin{array}{c}51-100 \\
\text { miles } \\
\text { away } \\
\end{array}$} & \multicolumn{2}{|c|}{$\begin{array}{c}\text { Over } \\
100 \text { miles } \\
\text { away } \\
\end{array}$} & \multirow[b]{2}{*}{ Total } \\
\hline & $\underline{\underline{\mathrm{f}}}$ & $\%$ & $\overline{\underline{f}}$ & $\%$ & $\overline{\mathrm{f}}$ & $\%$ & $\overline{\mathrm{f}}$ & $\%$ & $\overline{\underline{f}}$ & $\%$ & \\
\hline Nonrural* & 162 & 31.5 & 155 & 30.1 & 56 & 10.9 & 53 & 10.3 & 89 & 17.3 & 515 \\
\hline Rural* & 101 & 30.8 & 114 & 34.8 & 36 & 11.0 & 13 & 4.0 & 64 & 19.5 & 328 \\
\hline
\end{tabular}

$$
* \chi^{2}(4, \mathrm{~N}=846)=29.10, \underline{\mathrm{p}}<.001
$$

\section{Grandparents}

Figure 2 shows the frequency of the students' grandparents who were farmers for the students in AEA 4. A high percentage of the students (80.6\%) had grandparents who were farmers.

Table 36 shows the frequencies for private and public school students and students living in town or the country whose grandparents were farmers. The private school students had a

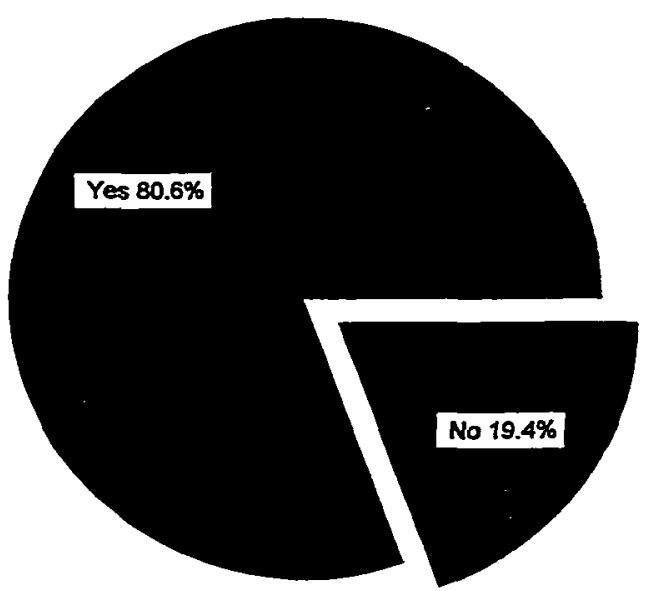

Figure 2. Grandparents were farmers 
greater percentage of grandparents who were farmers than public school students $(86.4 \%$ and

78.8\%). The students living in the country had the greatest percentage of grandparents who were farmers $(92.7 \%)$.

\section{Parents' farming background}

Table 37 shows that a greater percentage of private school students $(42.4 \%)$ had parents who farmed than public school students (23.8\%). Sixty-nine and eight-tenths percent of the rural students had parents who farmed.

Table 36. Frequency of students whose grandparents were farmers

\begin{tabular}{|c|c|c|c|c|}
\hline & \multicolumn{2}{|c|}{ Yes } & \multicolumn{2}{|c|}{ No } \\
\hline & $\underline{\underline{f}}$ & $\%$ & $\underline{\underline{f}}$ & $\%$ \\
\hline Public school seniors* & 514 & 78.8 & 138 & 21.2 \\
\hline Private school seniors* & 171 & 86.4 & 27 & 13.6 \\
\hline Students living in country*** & 305 & 92.7 & 24 & 7.3 \\
\hline Students living in town $* * *$ & 378 & 73.0 & 140 & 27.0 \\
\hline
\end{tabular}

$* \chi^{2}(1, \mathrm{~N}=850)=5.50, \mathrm{p}<.05$.

$* * * \chi^{2}(1, N=847)=50.18, \mathrm{p}<.001$.

Table 37. Frequency of private and public school and rural and nonrural students who were sons or daughters of a farmer

\begin{tabular}{|c|c|c|c|c|}
\hline & \multicolumn{2}{|c|}{ Yes } & \multicolumn{2}{|c|}{ No } \\
\hline & $\underline{\mathrm{f}}$ & $\overline{\%}$ & $\underline{f}$ & $\overline{\%}$ \\
\hline Nonrural *** & 16 & 22.4 & 450 & 87.2 \\
\hline Rural*** & 229 & 69.8 & 99 & 30.2 \\
\hline Private school seniors** & 84 & 42.4 & 114 & 57.6 \\
\hline Public school seniors** & 213 & 23.8 & 436 & 67.2 \\
\hline
\end{tabular}

$* * \chi^{2}(1, \mathrm{~N}=847)=6.17, \mathrm{p}<.01$.

$* * * \chi^{2}(1, N=844)=268.83, \mathrm{p}<.001$. 


\section{Students' Educational Background}

\section{Agriculture courses taken}

The frequencies of nonrural and rural students and private and public school students who took agriculture courses are shown in Table 38. Thirty-five and five-tenths percent of public school students had taken an agriculture course. Only $7.6 \%$ of private school students had taken an agriculture course. The percentage was low because the private schools did not offer agriculture courses.

Table 38. Frequencies of students who took agriculture courses

$\frac{\text { Yes }}{\underline{f}} \quad \frac{\text { No }}{\underline{\mathrm{f}}}$

$\begin{array}{lrrrr}\text { Nonrural } & 123 & 23.7 & 395 & 65.6 \\ \text { Rural } & 122 & 37.1 & 207 & 62.9 \\ \text { Private } & 15 & 7.6 & 183 & 92.4 \\ \text { Public } & 232 & 35.5 & 420 & 64.2\end{array}$

\section{FFA experience}

Table 39 shows the frequency of participation in FFA. FFA participation was minimal in the private schools. Ninety-seven and five-tenths percent of the seniors in private schools had no experience with FFA because FFA was not available in the private schools. Some FFA experience resulted from students transferring to the private schools from the public schools where they had been involved in FFA.

Table 39 shows that $72.5 \%$ of the seniors in the public schools had no FFA experience. Of all of the seniors in AEA 4, 8.9\% of them had participated in FFA for four or more years. 
Examining only the public schools, $11.5 \%$ of the seniors participated in FFA for four or more years.

Table 40 shows the students' involvement in FFA by where they lived. Of the 153 students who participated in FFA, 35.9\% lived in town, $21.6 \%$ lived on an acreage, $21.6 \%$ lived on a small farm, and $20.9 \%$ lived on a large farm.

Table 39. Frequency in participation in FFA for private and public school seniors

\begin{tabular}{|c|c|c|c|c|c|c|c|c|c|c|c|}
\hline \multirow{2}{*}{$\begin{array}{l}\text { FFA } \\
\text { participation }\end{array}$} & \multicolumn{2}{|c|}{0 years } & \multicolumn{2}{|c|}{1 year } & \multicolumn{2}{|c|}{2 years } & \multicolumn{2}{|c|}{3 years } & \multicolumn{2}{|c|}{$\begin{array}{l}4 \text { years } \\
\text { or more }\end{array}$} & \multirow[b]{2}{*}{ Total } \\
\hline & $\underline{\mathbf{f}}$ & $\%$ & $\underline{f}$ & $\%$ & $\underline{f}$ & $\%$ & $\underline{f}$ & $\%$ & $\underline{\mathbf{f}}$ & $\%$ & \\
\hline Private*** & 192 & 97.5 & 3 & 1.5 & 0 & 0.0 & 1 & 0.5 & 1 & 0.5 & 197 \\
\hline Public*** & 505 & 72.5 & 28 & 4.3 & 20 & 3.1 & 26 & 0.5 & 75 & 11.5 & 654 \\
\hline Missing & & & & & & & & & & & 12 \\
\hline Totals & 697 & 81.9 & 31 & 3.6 & 20 & 2.4 & 27 & 3.2 & 76 & 8.9 & 853 \\
\hline
\end{tabular}

Table 40. FFA students' level of participation by where they lived

\begin{tabular}{|c|c|c|c|c|c|c|c|c|c|c|}
\hline \multirow[b]{3}{*}{ Location } & \multicolumn{10}{|c|}{ FFA participation } \\
\hline & \multicolumn{2}{|c|}{1 vear } & \multicolumn{2}{|c|}{2 years } & \multicolumn{2}{|c|}{3 years } & \multicolumn{2}{|c|}{$\begin{array}{l}4 \text { years } \\
\text { or more }\end{array}$} & \multicolumn{2}{|c|}{ Total } \\
\hline & $\underline{f}$ & $\%$ & $\underline{\mathbf{f}}$ & $\%$ & $\underline{\mathrm{f}}$ & $\%$ & $\underline{f}$ & $\%$ & $\underline{f}$ & $\%$ \\
\hline Home in town & 14 & 25.5 & 7 & 4.5 & 12 & 21.8 & 22 & 40.0 & 55 & 35.9 \\
\hline Apartment & 0 & 0.0 & 0 & 0.0 & 0 & 0.0 & 0 & 0.0 & 0 & 0.0 \\
\hline Acreage & 6 & 18.2 & 5 & 15.2 & 8 & 24.2 & 14 & 42.4 & 33 & 21.6 \\
\hline Small farm & 6 & 18.2 & 3 & 9.1 & 5 & 15.2 & 19 & 57.6 & 33 & 21.6 \\
\hline Large farm & 5 & 15.6 & 4 & 12.5 & 2 & 63.0 & 21 & 65.6 & 32 & 20.9 \\
\hline Totals & 31 & 20.3 & 19 & 12.4 & 27 & 17.6 & 76 & 49.7 & 153 & \\
\hline
\end{tabular}

$* * * \chi^{2}(16, \mathrm{~N}=850)=70.40, \mathrm{p}<.001$ 
Table 41 shows FFA participation of nonrural and rural students. Rural students had significantly more FFA participation than nonrural students.

The percentage of FFA participation by rural students was greater for each year of FFA participation, and for the variable " 4 years or more" of FFA participation, $15.2 \%$ of rural students participated in FFA compared to $4.8 \%$ of the nonrural students. Five schools had FFA membership in the senior class of ten or more students. The range in FFA membership in the senior class for the five schools was 13 to 28 students. The range of FFA membership of the remaining seven public schools was 2 to 9 students. The private schools had a range of 0 to 2 students who had FFA experience in the senior class.

Table 41. FFA participation of nonrural and rural students

\begin{tabular}{|c|c|c|c|c|c|c|c|c|c|c|}
\hline \multirow{2}{*}{$\begin{array}{l}\text { FFA } \\
\text { participation }\end{array}$} & \multicolumn{2}{|c|}{0 years } & \multicolumn{2}{|c|}{1 vear } & \multicolumn{2}{|c|}{2 years } & \multicolumn{2}{|c|}{3 years } & \multicolumn{2}{|c|}{$\begin{array}{l}4 \text { years } \\
\text { or more }\end{array}$} \\
\hline & $\underline{f}$ & $\%$ & $\underline{f}$ & $\%$ & $\underline{f}$ & $\%$ & $\underline{f}$ & $\%$ & $\underline{f}$ & $\%$ \\
\hline Nonrural*** & 460 & 88.5 & 14 & 2.7 & 8 & 1.5 & 13 & 2.5 & 25 & 4.8 \\
\hline Rural*** & 236 & 72.0 & 17 & 5.2 & 11 & 3.4 & 14 & 4.3 & 50 & 15.2 \\
\hline Total & 696 & 82.1 & 31 & 3.7 & 19 & 2.2 & 27 & 3.2 & 75 & 8.8 \\
\hline
\end{tabular}

$* * * \chi^{2}(4, \mathrm{~N}=848)=39.80, \mathrm{p}<.001$

Table 42 shows the aspirations to continue their education of the students who were involved in FFA and those who were not involved in FFA. Students with FFA experience were less inclined to continue their education (83.1\%) compared to the students who were not involved in FFA (92\%). Table 43 shows that the students who participated in FFA had less of an intention to continue their education than the students who had not participated in FFA. The difference in the means was significantly different. 
Table 42. FFA involvement and aspirations for continued education

\begin{tabular}{|c|c|c|c|c|c|}
\hline \multirow{2}{*}{$\begin{array}{l}\text { FFA } \\
\text { participation }\end{array}$} & \multicolumn{2}{|c|}{$\begin{array}{c}\text { Plans to continue } \\
\text { education }\end{array}$} & \multicolumn{2}{|c|}{$\begin{array}{c}\text { Do not plan to } \\
\text { continue education }\end{array}$} & \multirow[b]{2}{*}{ Total } \\
\hline & $\underline{f}$ & $\%$ & $\underline{\mathbf{f}}$ & $\%$ & \\
\hline \multicolumn{6}{|l|}{ Students with } \\
\hline FFA participation & 128 & 83.1 & 26 & 16.9 & 154 \\
\hline Students without & & & & & \\
\hline FFA participation & 641 & 92.0 & 56 & 8.0 & 697 \\
\hline Missing & & & & & 2 \\
\hline Totals & 769 & 90.4 & 82 & 9.6 & 853 \\
\hline
\end{tabular}

Table 43. Means and standard deviations for continuing their education for students who participated and did not participate in $\mathrm{FFA}^{2}$

\begin{tabular}{lccccc}
\hline & $\mathrm{M}$ & $\mathrm{SD}$ & $\mathrm{N}$ & $\mathrm{t}$ & $\mathrm{F}$ \\
\hline Participated in FFA & 1.69 & 1.15 & 154 & $3.47^{* * *}$ & 36.51 \\
Nonparticipant in FFA & 1.36 & .79 & 697 & & \\
\hline
\end{tabular}

${ }^{2}$ Scale: $1=$ Definitely attend, $2=$ Likely attend, $3=$ Unsure, $4=$ Not likely, $5=$ Definitely not attend.

$* * * \mathrm{p}<.001$.

The students who attended only public schools were examined for FFA participation and enrollment in agriculture courses. Table 44 shows significant differences in the students' intentions of continuing their education. Students who had taken agriculture courses or participated in FFA were significantly less inclined to continue their education. 
Table 44. Means and standard deviations for public school students for continuing their education for students who took and did not take agriculture courses and for students who did and did not participate in FFA

\begin{tabular}{lccccc}
\hline & $\mathrm{M}$ & $\mathrm{SD}$ & $\mathrm{N}$ & $\mathrm{t}$ & $\mathrm{F}$ \\
\hline Participated in FFA & 1.64 & 1.10 & 149 & $3.49 * * *$ & 40.57 \\
Nonparticipant in FFA & 1.31 & 0.73 & 505 & & \\
$\begin{array}{l}\text { Took one or more agriculture } \\
\text { courses }\end{array}$ & 1.55 & 1.03 & 232 & $3.40 * * *$ & 41.33 \\
$\begin{array}{l}\text { Took no agriculture courses } \\
\text { Took }\end{array}$ & 1.30 & 0.70 & 420 & & \\
\hline
\end{tabular}
attend.

${ }^{\mathrm{a}}$ Scale: $1=$ Definitely attend, 2 =Likely attend, $3=$ Unsure, $4=$ Not likely, $5=$ Definitely not $* * * \mathrm{p}<.001$

\section{4-H experience}

Table 45 shows the 4-H participation of the seniors in private and public schools and nonrural and rural students. The percentage participation in 4-H was greater in the public schools (27\%) than in the private schools (14.7\%). The total participation in 4-H was $24.1 \%$ of the students. For comparison, $8.9 \%$ of the seniors in AEA 4 had participated in FFA (see Table 39) compared to $24.1 \%$ who had participated in $4-\mathrm{H}$.

\section{Extracurricular activity}

The extracurricular activity participation frequencies are shown in Table 46 . The rural students had a significantly higher frequency of being an officer of an organization than students living in town, but the differences for the other extracurricular activities were not significantly different. 
Table 45 . Participation in $4-\mathrm{H}$ by private and public school seniors and nonrural and rural seniors

\begin{tabular}{|c|c|c|c|c|c|c|c|c|}
\hline \multirow{2}{*}{$\begin{array}{l}\text { 4-H } \\
\text { participation }\end{array}$} & \multicolumn{2}{|c|}{ Private***1 } & \multicolumn{2}{|c|}{ Public***I } & \multicolumn{2}{|c|}{ Nonrural $* * * 2$} & \multicolumn{2}{|c|}{$\underline{\text { Rural } * * * 2}$} \\
\hline & $\underline{f}$ & $\%$ & $\underline{\mathrm{f}}$ & $\%$ & $\underline{f}$ & $\%$ & $\underline{f}$ & $\%$ \\
\hline \multirow{3}{*}{$\begin{array}{l}\text { Participated in 4-H } \\
\text { Did not participate } \\
\text { in 4-H }\end{array}$} & 29 & 14.7 & 176 & 27.0 & 95 & 18.4 & 109 & 33.1 \\
\hline & & & & & & & & \\
\hline & 168 & 85.3 & 475 & 73.0 & 421 & 81.6 & 220 & 66.9 \\
\hline
\end{tabular}

Table 46. Extracurricular activity participation frequencies of nonrural and rural students

\section{Extracurricular activity}
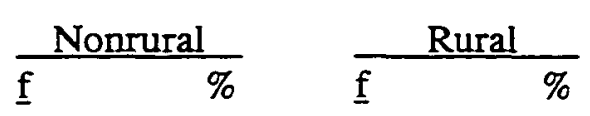

Participated in sports in school, church, town

Did not participate in sports in school, church, or town

Officer in school, church, or community group*

Not an officer in school, church, or community group*

Participated in band, choir, or musical group in school

Did not participate in band, choir, or musical group

Participated in a play or academic team competition

Did not participate in a play or academic team

competition

423

95

241

277

379

139

238

81.7

18.3

266

46.5

62

81.1

53.5

184

18.9

73.2

145

55.9

26.8

44.1

73.8

46.0

26.2

279

54.0

186

56.7

$$
{ }^{*} \mathrm{p}<.05 ; \chi^{2}(1, \mathrm{~N}=846)=7.11
$$

Table 47 shows the extracurricular activity participation frequencies for private and public school students. The public school students had a significantly higher frequency of sports participation than the private school students. The students from private schools had a significantly higher frequency in their participation in musical activities. 
Table 47. Extracurricular activity participation frequencies of private and public school students

Extracurricular activity

$\frac{\text { Private }}{\mathrm{f}} \quad \frac{\text { Public }}{\mathrm{f}}$

Participated in sports in school, church, town* 145

Did not participate in sports in school, church, or town*

Not an officer in school, church, or community group

$* \mathrm{p}<.001 ; \chi^{2}(1, \mathrm{~N}=849)=11.35$

** $\mathrm{p}<.001 ; \chi^{2}(1, \mathrm{~N}=849)=34.25$.

An analysis of the frequency of participation in extracurricular activities by males and females is shown in Table 48. Males were significantly more involved in sports, but the females were significantly more involved in being an officer of an organization, participating in musical activities, and participating in a play or academic team competition.

Tables 49 and 50 analyze the extracurricular activities of males and females in private and public schools. Table 49 shows that the males and females in private schools had significantly different frequencies of participation of being an officer of an organization and participating in musical activities. The frequencies of participation in sports activities and the frequencies of participation in class plays or an academic competition were not statistically different.

Table 50 shows the frequencies of participation for the public schools. Sports participation and participation in musical activities were statistically different. The frequency of participation of the males in sports was significantly greater than for females; the females participated in musical 
Table 48. Extracurricular activity participation frequencies of males and females

Extracurricular activity

Participated in sports in school, church, town**

Did not participate in sports in school, church, or town**

Officer in school, church, or community group*

Not an officer in school, church, or community group*

Participated in band, choir, or musical group in school***

Did not participate in band, choir, or musical group ${ }^{* * *}$

Participated in a play or academic team competition

Did not participate in a play or academic team

competition

$\frac{\text { Males }}{\%}$

$$
\begin{gathered}
* \mathrm{p}<.05 ; \chi^{2}(1, \mathrm{~N}=847)=4.71 \\
* * \mathrm{p}<.01 ; \chi^{2}(1, \mathrm{~N}=846)=6.33 \\
* * * \mathrm{~g}<.001 ; \chi^{2}(1, \mathrm{~N}=846)=65.44
\end{gathered}
$$

Table 49. Extracurricular activity participation frequencies of males and females in private schools
Extracurricular activity

Participated in sports in school, church, town

Did not participate in sports in school, church, or town

Officer in school, church, or community group*

Not an officer in school, church, or community group*

Participated in band, choir, or musical group in school**

Did not participate in band, choir, or musical group**

Participated in a play or academic team competition

Did not participate in a play or academic team competition

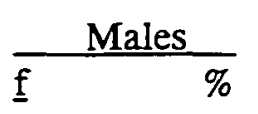

$\underline{f}$
Females

68

207

238

274

170

198

\section{4}

15.3

46.5

53.5

61.7

38.3

44.7

53.3

\section{4}

89

217

185

347

55

182

220
77.9

22.1

54.0

46.0

86.3

43.7

45.3

54.7 
Table 50. Extracurricular activity participation frequencies of males and females in public schools

\begin{tabular}{|c|c|c|c|c|}
\hline \multirow[b]{2}{*}{ Extracurricular activity } & \multicolumn{2}{|c|}{ Males } & \multicolumn{2}{|c|}{ Females } \\
\hline & $\underline{\mathbf{f}}$ & $\%$ & $\underline{\mathrm{f}}$ & $\%$ \\
\hline Participated in sports in school, church, town* & 298 & 87.1 & 246 & 80.4 \\
\hline Did not participate in sports in school, church, or town* & 44 & 12.9 & 60 & 19.6 \\
\hline Officer in school, church, or community group & 168 & 48.8 & 163 & 53.4 \\
\hline Not an officer in school, church, or community group & 176 & 51.2 & 142 & 46.6 \\
\hline Participated in band, choir, or musical group in school** & 189 & 54.9 & 256 & 83.9 \\
\hline Did not participate in band, choir, or musical group** & 155 & 45.1 & 49 & 16.1 \\
\hline Participated in a play or academic team competition & 154 & 45.0 & 146 & 47.9 \\
\hline Did not participate in a play or academic team & & & & \\
\hline competition & 188 & 55.0 & 159 & 52.1 \\
\hline
\end{tabular}

$$
\begin{aligned}
* \mathrm{p}<.05 ; \chi^{2}(1, \mathrm{~N}=648) & =5.45 \\
* * \mathrm{p} & <.01 ; \chi^{2}(1, \mathrm{~N}=649)=63.05
\end{aligned}
$$

activities at a significantly greater frequency than the males. There was no significant difference of frequency of participation for males and females for participation in plays or academic competitions nor participating as an officer in a school, church, or community group.

\section{Courses taken}

Table 51 shows the frequencies of students taking different high school courses that were indicative of their high school program track. Courses in trigonometry, calculus, and geometry were considered courses that would be taken by students planning to attend college. Similarly, courses taken in physics, chemistry, and foreign languages were given the same consideration. The analysis of courses taken by rural and nonrural students showed a difference between nonrural and rural students. A greater percentage of rural students took courses in either calculus, trigonometry, or geometry than the nonrural students $(76.6 \%$ versus $70.2 \%)$. The percentage of 
rural students who took either physics or chemistry was greater than the nonrural students $(65.7 \%$ versus $63.8 \%$ ). Conversely, a greater percentage of nonrural students took courses in foreign languages than the rural student $(86.1 \%$ versus $79.3 \%$ ). A chi-square analysis showed a significant difference in the frequency of distribution between rural students and nonrural students. The nonrural students enrolled in foreign language courses more frequently than the rural students.

The measure of association used to analyze the dependent variables was the Phi coefficient which is a special case of the Pearson product-moment coefficient used to measure the association of dichotomous nominal data. The levels of association between rural students and nonrural students and the courses they took were .10 for foreign language, .08 for either calculus, trigonometry, or geometry, and .06 for chemistry or physics. Using Davis' descriptors, the values of association were negligible to low.

Table 52 shows the same variables from Table 51 for private and public school students. A significantly greater percentage of public school students had taken chemistry or physics than srudents from private schools.

Table 51 . Frequencies of specific courses taken by nonrural and rural students $(N=849)$

Courses

taken

\begin{tabular}{cc} 
Nonrural \\
\hline$\underline{f}$ & $\mathrm{~N}$
\end{tabular}

\section{2}

63.8

86.1

\section{0}

520

519

\begin{tabular}{cc}
\multicolumn{3}{c}{ Rural } \\
\hline$\underline{\mathrm{f}}$ & $\%$
\end{tabular}

Took a foreign language*

$$
{ }^{*} \chi^{2}(4, N=846)=7.5, \underline{\mathrm{p}}<.05 \text {. }
$$


Table 52. Frequencies of specific courses taken by private and public school students $(N=849)$

Courses

taken

Took calculus, trigonometry, geometry

Took physics or chemistry*

Took a foreign language

$\frac{\text { Private }}{\%} \quad \mathrm{~N}$

146

113

167

73.7

57.4

84.3

198
197
198

472

436

542

$$
* \chi^{2}(1, N=849)=5.99, \underline{p}<.05
$$

Table 53 shows the frequencies of the seniors who took either a technical drawing or shop class among rural and nonrural sudents and among private and public school students. There was a significant difference in the frequencies between the private and public schools. One of the private schools had no course offerings in technical drawing or shop (Netherlands Reformed).

Table 53. Frequencies of students who took a technical drawing or shop class

\begin{tabular}{|c|c|c|c|c|}
\hline & \multicolumn{2}{|c|}{ Yes } & \multicolumn{2}{|c|}{ No } \\
\hline & $\underline{\underline{f}}$ & $\overline{\%}$ & $\underline{\mathrm{f}}$ & $\%$ \\
\hline Nonrural & 269 & 51.9 & 249 & 48.1 \\
\hline Rural & 168 & 51.1 & 161 & 48.9 \\
\hline Private schools** & 83 & 41.9 & 115 & 58.1 \\
\hline Public schools** & 357 & 54.8 & 295 & 45.2 \\
\hline
\end{tabular}

$$
* *_{\mathrm{p}}<.01 ; \chi^{2}(1, \mathrm{~N}=850)=10.02
$$




\section{Distance located from school}

Table 54 shows the distances private and public school students and nonrural and rural students lived from school. The "0-5 miles" and "6-10 miles" categories were combined. The combined total was $82.7 \%$ for public school students and $39.5 \%$ for private school students. For the combined categories, $82.6 \%$ of the nonrural students and $63.4 \%$ of the rural students were included.

The "16-20 miles" and "21 and over miles" categories were combined. The combined category included $26.2 \%$ of the private school students, $4.3 \%$ of the public school students, $5.6 \%$ of the nonrural students, and $15.5 \%$ of the rural students.

The differences between private and public school students and the differences between nonrural and rural students were significantly different. The private school students lived greater distances from their school.

Table 54. Distance students live from school

\begin{tabular}{|c|c|c|c|c|c|c|c|c|c|c|c|}
\hline & \multicolumn{2}{|c|}{$0-5$ miles } & \multicolumn{2}{|c|}{ 6-10 miles } & \multicolumn{2}{|c|}{$11-15$ miles } & \multicolumn{2}{|c|}{$16-20$ miles } & \multicolumn{2}{|c|}{$\geq 21$ miles } & \multirow[b]{2}{*}{$\mathrm{N}$} \\
\hline & $\underline{\mathbf{f}}$ & $\%$ & $\underline{f}$ & $\%$ & $\underline{\mathrm{f}}$ & $\%$ & $\underline{f}$ & $\%$ & $\underline{\mathrm{f}}$ & $\%$ & \\
\hline Private $^{2}$ & 56 & 28.3 & 42 & 21.2 & 48 & 24.2 & 27 & 13.6 & 25 & 12.6 & 198 \\
\hline Public $^{\mathbf{a}}$ & 377 & 57.7 & 163 & 25.0 & 85 & $13 . .0$ & 20 & 3.1 & 8 & 1.2 & 653 \\
\hline Nonrural $^{b}$ & 338 & 65.1 & 91 & 17.5 & 61 & 11.8 & 17 & 3.3 & 12 & 2.3 & 519 \\
\hline Rural $^{b}$ & 94 & 28.6 & 114 & 34.7 & 70 & 21.3 & 30 & 9.1 & 21 & 6.4 & 329 \\
\hline
\end{tabular}

$$
\begin{aligned}
& { }^{2} \chi^{2}(4, \mathrm{~N}=851)=120.72, \mathrm{p}<.01 \\
& { }^{\mathrm{b}} \chi^{2}(4, \mathrm{~N}=848)=110.02, \mathrm{p}<.01 .
\end{aligned}
$$




\section{Student Perceptions and Desires}

\section{Student perceptions of community}

The perceptions of the seniors about their community is shown in Table 55. The percentage of students who lived in a house in town who had the perception that their community was either "An average place to live," "A good place to live," or "A great place to live" was $86.7 \%$, those in an apartment in town was $40 \%$, those on an acreage was $89.1 \%$, those on a small farm was 92.4\%, and those on a large farm was $91.9 \%$. An analysis of variance shows in Table 56 that the perceptions about their community of those who resided in an apartment in town were significantly more negative than those students who lived in the country or who lived in a house in town.

Table 55. Student perception of community by location of where they lived

\begin{tabular}{|c|c|c|c|c|c|c|c|c|c|c|c|}
\hline \multirow{2}{*}{$\begin{array}{l}\text { Community } \\
\text { perception }\end{array}$} & \multicolumn{2}{|c|}{$\begin{array}{l}\text { Great } \\
\text { place }\end{array}$} & \multicolumn{2}{|c|}{$\begin{array}{l}\text { Good } \\
\text { place }\end{array}$} & \multicolumn{2}{|c|}{$\begin{array}{l}\text { Average } \\
\text { place }\end{array}$} & \multicolumn{2}{|c|}{$\begin{array}{c}\text { Not } \\
\text { desirable }\end{array}$} & \multicolumn{2}{|c|}{$\begin{array}{c}\text { Very } \\
\text { undesirable }\end{array}$} & \multirow[b]{2}{*}{ Total } \\
\hline & $\underline{f}$ & $\%$ & $\underline{f}$ & $\%$ & $\underline{f}$ & $\%$ & $\underline{f}$ & $\%$ & $\underline{f}$ & $\%$ & \\
\hline House in town & 84 & 17.1 & 228 & 46.5 & 113 & 23.1 & 51 & 10.4 & 14 & 2.9 & 490 \\
\hline Apartment in town & 1 & 2.5 & 2 & 25.0 & 1 & 12.5 & 1 & 12.5 & 3 & 37.5 & 8 \\
\hline Acreage & 28 & 19.0 & 72 & 49.0 & 31 & 21.1 & 11 & 7.5 & 5 & 3.4 & 147 \\
\hline Small farm & 39 & 29.5 & 55 & 41.7 & 28 & 21.2 & 6 & 4.5 & 4 & 3.0 & 132 \\
\hline Large farm & 17 & 23.0 & 35 & 47.3 & 16 & 21.6 & 6 & 8.1 & 0 & 0.0 & 74 \\
\hline Missing & & & & & & & & & & & 2 \\
\hline Total & 169 & 19.9 & 392 & 46.1 & 189 & 22.2 & 75 & 8.8 & 26 & 3.1 & 853 \\
\hline
\end{tabular}


Table 56. Analysis of variance of the community perceptions of students based on where they lived $(\mathrm{N}=853)^{\mathrm{a}}$

\begin{tabular}{llrr}
\hline Location & M & SD & $F^{b}$ \\
\hline House in town & 2.35 & .98 & $4.68^{* *}$ \\
Apartment in town & $3.38^{\mathrm{c}}$ & 1.60 & \\
Acreage & 2.27 & .97 & \\
Small farm & 2.10 & .98 & .87 \\
Large farm & 2.15 & & \\
\hline
\end{tabular}

${ }^{2}$ Scale: $1=$ Great place to live, $2=$ Good place to live, $3=$ Average place to live, $4=$ Undesirable place to live, $5=$ Very undesirable place to live.

${ }^{b} \mathrm{~F}(4,846)$.

'Denotes mean of group that is significantly different using a Schéffé post hoc test. $* * \underline{p}<.01$.

Table 57 shows the differences in community perception by examining those who lived in town (nonrural) and those who lived in the country (rural). An independent t-test of the rural and nonrural groups shows in Table 58 that the rural students had a significantly more positive perception of their community than the nonrural students. Table 59 shows the frequencies of

Table 57. Student perception of community by rural and nonrural students

\begin{tabular}{|c|c|c|c|c|c|c|c|c|c|c|c|}
\hline & \multicolumn{2}{|c|}{$\begin{array}{l}\text { Great } \\
\text { place }\end{array}$} & \multicolumn{2}{|c|}{$\begin{array}{l}\text { Good } \\
\text { place }\end{array}$} & \multicolumn{2}{|c|}{$\begin{array}{l}\text { Average } \\
\text { place }\end{array}$} & \multicolumn{2}{|c|}{$\begin{array}{c}\text { Not } \\
\text { desirable }\end{array}$} & \multicolumn{2}{|c|}{$\begin{array}{c}\text { Very } \\
\text { undesirable }\end{array}$} & \multirow[b]{2}{*}{ Total } \\
\hline & $\underline{f}$ & $\overline{\%}$ & $\underline{\mathrm{f}}$ & $\%$ & $\underline{\mathrm{f}}$ & $\%$ & $\underline{\mathbf{f}}$ & $\%$ & $\underline{\mathbf{f}}$ & $\%$ & \\
\hline Rural & 78 & 23.7 & 153 & 46.5 & 71 & 21.6 & 19 & 5.8 & 8 & 2.4 & 329 \\
\hline $\begin{array}{l}\text { Nonrural } \\
\text { Missing }\end{array}$ & 86 & 16.5 & 232 & 44.6 & 122 & 23.5 & 61 & 11.7 & 19 & 3.7 & $\begin{array}{r}520 \\
4\end{array}$ \\
\hline Total & 164 & 19.3 & 385 & 45.3 & 193 & 22.7 & 80 & 9.4 & 27 & 3.2 & 853 \\
\hline
\end{tabular}


Table 58. Means and standard deviations of student perception of community of rural and nonrural students ${ }^{2}$

\begin{tabular}{lcccc}
\hline & M & SD & N & $t$ \\
\hline Rural** & 2.17 & .94 & 329 & -3.01 \\
Nonrural** & 2.41 & 1.01 & 520 & \\
\hline
\end{tabular}

${ }^{2}$ Scale: $1=$ Great place, $2=$ Good place, $3=$ Average place, $4=$ Not desirable, $5=$ Very undesirable.

${ }^{* *} \mathrm{p}<.01$.

Table 59. Student perception of community by seniors in private and public schools

\begin{tabular}{|c|c|c|c|c|c|c|c|c|c|c|c|}
\hline & \multicolumn{2}{|c|}{$\begin{array}{l}\text { Great } \\
\text { place }\end{array}$} & \multicolumn{2}{|c|}{$\begin{array}{l}\text { Good } \\
\text { place }\end{array}$} & \multicolumn{2}{|c|}{$\begin{array}{l}\text { Average } \\
\text { place }\end{array}$} & \multicolumn{2}{|c|}{$\begin{array}{c}\text { Not } \\
\text { desirable }\end{array}$} & \multicolumn{2}{|c|}{$\begin{array}{c}\text { Very } \\
\text { undesirable }\end{array}$} & \multirow[b]{2}{*}{ Total } \\
\hline & $\underline{\mathbf{f}}$ & $\overline{\%}$ & $\underline{\underline{f}}$ & $\%$ & $\underline{f}$ & $\%$ & $\overline{\mathrm{f}}$ & $\%$ & $\underline{f}$ & $\%$ & \\
\hline Private & 61 & 30.8 & 92 & 46.5 & 34 & 17.2 & 8 & 4.0 & 3 & 1.5 & 198 \\
\hline $\begin{array}{l}\text { Public } \\
\text { Missing }\end{array}$ & 103 & 15.7 & 295 & 45.1 & 159 & 24.3 & 73 & 11.2 & 24 & 3.7 & $\begin{array}{r}654 \\
1\end{array}$ \\
\hline Total & 164 & 19.2 & 387 & 45.4 & 193 & 22.7 & 81 & 9.5 & 27 & 3.2 & 853 \\
\hline
\end{tabular}

their perceptions of their community by seniors in the private and public schools. Combining the categories of "Great place," "Good place," and "Average place," the combined category included $94.5 \%$ of the seniors in private schools and $85.1 \%$ of the seniors in the public schools.

An independent t-test comparing the means of the private and public schools is shown in Table 60 . The community perception of the private school students was significantly more positive than the perception of community by the public school students. 
Table 60. Means and standard deviations of community perception of students in private and public schools ${ }^{2}$

\begin{tabular}{lcccc}
\hline & $\mathrm{M}$ & $\mathrm{SD}$ & $\mathrm{N}$ & $\mathrm{t}$ \\
\hline Private school*** & 1.99 & 1.00 & 198 & 5.31 \\
Public*** $^{*}$ & 2.38 & .88 & & \\
\hline
\end{tabular}

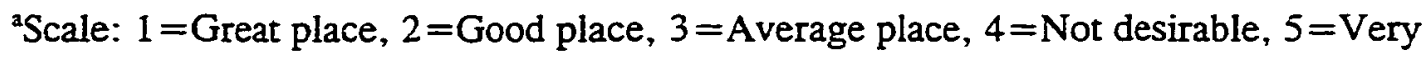
undesirable. $* * * \mathrm{p}<.001$.

\section{Community desires}

The importance of community for their future adulthood was measured by asking the students for their perceptions of the importance of the dependent variables in Tables 61 and 62 . Rural and nonrural students were examined, and private and public school students were examined. There were no significant differences in the means of the dependent variables between

Table 61. Importance of community desires in adulthood for nonrural and rural students ${ }^{\mathrm{a}}$

\begin{tabular}{|c|c|c|c|c|c|c|c|}
\hline \multirow{2}{*}{$\begin{array}{l}\text { Community } \\
\text { desires }\end{array}$} & \multicolumn{2}{|c|}{$\mathbf{M}$} & \multicolumn{2}{|c|}{$\mathrm{SD}$} & \multicolumn{2}{|l|}{$\mathbf{N}$} & \multirow[b]{2}{*}{$\mathrm{t}$} \\
\hline & Nonrural & Rural & Nonrural & Rural & Nonrural & Rural & \\
\hline \multicolumn{8}{|l|}{ Provide volunteer service } \\
\hline in my community & 2.03 & 2.00 & 0.67 & 0.62 & 519 & 328 & -0.65 \\
\hline Work to correct social and & & & & & & & \\
\hline economic problems & 2.12 & 2.05 & 0.67 & 0.65 & 519 & 328 & -1.55 \\
\hline Voting in elections & 1.88 & 1.82 & 0.70 & 0.65 & 519 & 328 & -1.27 \\
\hline \multicolumn{8}{|l|}{ Help improve and care } \\
\hline for environment & 1.85 & 1.81 & 0.62 & 0.60 & 520 & 328 & -0.76 \\
\hline
\end{tabular}

${ }^{2}$ Scale: $1=$ Very important, 2 =Somewhat important, $3=$ Not important. 
Table 62. Importance of community desires in adulthood for private and public school students ${ }^{2}$

\section{Community}

desires

$\frac{\mathrm{M}}{\text { Private } \quad \text { Public }} \frac{\mathrm{SD}}{\text { Private Public }} \frac{\mathrm{N}}{\text { Private Public }}$

\begin{tabular}{llllllll}
$\begin{array}{l}\text { Provide volunteer service } \\
\text { in my community }\end{array}$ & 1.94 & 2.04 & 0.66 & 0.65 & 196 & 652 & 1.85 \\
$\begin{array}{l}\text { Work to correct social and } \\
\quad \text { economic problems }\end{array}$ & 2.09 & 2.10 & 0.70 & 0.65 & 198 & 652 & 0.29 \\
$\begin{array}{l}\text { Voting in elections } \\
\text { Help improve and care }\end{array}$ & $1.77^{*}$ & $1.89 *$ & 0.67 & 0.69 & 198 & 652 & 2.23 \\
$\quad$ for environment & 1.88 & 1.83 & 0.60 & 0.62 & 198 & 652 & -1.07 \\
\hline
\end{tabular}

${ }^{2}$ Scale: $1=$ Very important, $2=$ Somewhat important, $3=$ Not important.

${ }^{*} \mathrm{p}<.05$.

the rural and nonrural students. In Table 62, the mean of the dependent variable, "Voting in elections," was significantly more important to the students in private schools than the students in public schools.

\section{Education perceptions}

The students responded to the dependent variables that were intended to identify factors that would improve their future opportunities. Table 63 shows the means of their responses of nonrural and rural students. "Have more financial help to obtain schooling," "Have better paying jobs in the community," "Offer more job training courses," and "Offer more college courses in high school" had a mean between one and two, which was between "Very important" and "Somewhat important." There were no significant differences between the students who lived in the country and who lived in town. The students expressed similar views concerning the improvement of their future opportunities. The students expressed greater importance of having college courses offered in their high schools than having college courses available over the Internet. 
Table 63. Factors that could improve students' future opportunities for nonrural and rural students ${ }^{2}$

Factors that improve future opportunities

$\frac{M}{\text { Nonrural Rural }} \frac{\mathrm{SD}}{\text { Nonrural Rural }} \frac{\mathrm{N}}{\text { Nonrural Rural }} \mathrm{t}$

Offer more college courses

in high school

1.85

1.80

0.68

0.69

520

$328-0.86$

Offer more job training courses

1.79

1.80

0.67

0.67

520

328

0.23

Have college courses available on Internet

Have better paying jobs in community

2.18

2.18

0.74

0.71

520

328

0.42

Share teachers and courses with other schools

If I lived in a city

1.77

1.80

0.73

0.71

$519 \quad 328$

0.31

2.40

2.38

0.69

0.68

520

$\begin{array}{ll}328 & -0.49\end{array}$

Have more financial help to obtain schooling

2.42

0.75

0.71

520

328

1.66

$\begin{array}{lllllll}1.77 & 1.77 & 0.76 & 0.77 & 519 & 328 & 0.12\end{array}$

${ }^{2}$ Scale: 1 =Very important, 2 =Somewhat important, $3=$ Not important.

Table 64 shows the same factors for improving the student's future opportunities for private and public school students. Similar to what was reported in Table 63 for nonrural and rural, the students in private and public schools expressed the importance of offering college courses in high school, offering more job training courses, having better paying jobs in the community, and having more financial help to obtain schooling.

Table 64 shows significant differences in the levels of importance they placed on the dependent variables listed in the table. The public school students placed more importance than the private school students on all of the variables listed. Public school students placed significantly more importance on having access to college courses over the Internet than private school students. Public school students placed significantly more importance on having better paying jobs 
in their communities. Public school students also placed significantly more importance on sharing teachers and courses with other schools. The students in public schools also expressed importance on the factor of "If I lived in the city," and the difference in the means was significant at $\mathrm{p}<.01$. The students placed the most importance on having more financial help to obtain schooling (1.79 for the private schools and 1.77 for the public schools). The next most important factor was having access to more job training courses in high school.

Table 64. Factors that could improve students' future opportunities for private and public school students ${ }^{\mathbf{2}}$

Factors that improve future opportunities

$\frac{\mathrm{M}}{\text { Private }}$ Public $\frac{\mathrm{SD}}{\text { Private Public }} \frac{\mathrm{N}}{\text { Private Public }}$

Offer more college courses in high school 1.84 1.83

0.68

0.68

$\begin{array}{lll}198 & 653 & -1.80\end{array}$

Offer more job training courses

\subsection{3}

1.79

0.68

0.67

198

653

0.72

Have college courses available on Internet

Have better paying jobs in community

$2.36 *$

2.13*

0.67

0.74

198

$653-3.95$

Share teachers and courses with other schools

If I lived in a city

$\begin{array}{lllllll}1.97^{*} & 1.74^{*} & 0.73 & 0.72 & 198 & 652 & -4.01\end{array}$

Have more financial help to obtain schooling

\section{$2.47 *$}

$2.44 * *$

$2.37 *$

$2.34 * *$

0.64

0.69

0.69

0.75

198

198

$\begin{array}{ll}653 & -1.93\end{array}$

1.79

1.77

0.78

0.76

198

$652-0.32$

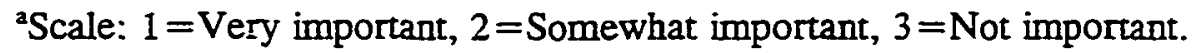
${ }^{*} \mathrm{p}<.05$.

${ }^{* *} \mathrm{p}<.01$. 


\section{Economic perceptions}

The importance of the dependent variables concerning economic factors and attitudes toward work by nonrural and rural students is shown in Table 65 . Table 66 shows the same dependent variables for students from private and public schools. The means for the variable, "Be able to support myself," shows that rural students were significantly less concerned about supporting themselves than nonrural students. The private school students placed significantly less importance than the public school students on the variables, "Be able to support myself" and "Having lots of money." The means show that the students from private schools were significantly less concerned about having lots of money and had less concerns about supporting themselves in adulthood than students from the public schools. There were no statistically significant differences for the variable, "Being successful in my job career," for nonrural, rural, private school, and public school students. Students placed high importance on being successful in their job career.

Table 65. Importance of economic desires in adulthood for nonrural and rural students ${ }^{2}$

\begin{tabular}{|c|c|c|c|c|c|c|c|}
\hline \multirow{2}{*}{$\begin{array}{l}\text { Economic } \\
\text { desires }\end{array}$} & \multicolumn{2}{|c|}{$M$} & \multicolumn{2}{|c|}{ SD } & \multicolumn{2}{|l|}{$\mathbf{N}$} & \multirow[b]{2}{*}{$\mathrm{t}$} \\
\hline & Nonrural & Rural & Nonrural & Rural & Nonrural & Rural & \\
\hline Being able to support myself & $1.16^{*}$ & $1.24^{*}$ & 0.44 & 0.49 & 518 & 328 & 2.35 \\
\hline Having lots of money & 1.92 & 1.94 & 0.67 & 0.68 & 518 & 327 & 0.50 \\
\hline Being successful in my & & & & & & & \\
\hline job career & 1.16 & 1.14 & 0.58 & 0.39 & 515 & 325 & -0.62 \\
\hline
\end{tabular}

${ }^{2}$ Scale: $1=$ Very important, 2 =Somewhat important, $3=$ Not important. ${ }^{*} \mathrm{p}<.05$. 
Table 66. Importance of economic desires in adulthood for private and public school students ${ }^{2}$

\begin{tabular}{|c|c|c|c|c|c|c|c|}
\hline \multirow{2}{*}{$\begin{array}{l}\text { Economic } \\
\text { desires }\end{array}$} & \multicolumn{2}{|c|}{$\mathbf{M}$} & \multicolumn{2}{|c|}{$S D$} & \multicolumn{2}{|c|}{$\mathrm{N}$} & \multirow[b]{2}{*}{$t$} \\
\hline & Private & Public & Private & Public & Private & Public & \\
\hline Being able to support myself & $1.28 *$ & $1.17^{*}$ & 0.51 & 0.45 & 197 & 652 & -2.73 \\
\hline $\begin{array}{l}\text { Having lots of money } \\
\text { Being successful in my }\end{array}$ & $2.09 *$ & $1.87^{*}$ & 0.72 & 0.66 & 197 & 651 & -4.01 \\
\hline job career & 1.17 & 1.16 & 0.35 & 0.55 & 197 & 646 & 1.42 \\
\hline
\end{tabular}

${ }^{2}$ Scale: $1=$ Very important, $2=$ Somewhat important, $3=$ Not important. ${ }^{*} \mathrm{p}<.05$.

\section{Personal time perceptions}

Tables 67 and 68 examine the variables related to the students' interest in their personal use of time. The rural students placed significantly less importance on "Travel outside the United States" than the nonrural student, which is shown in Table 67. Table 68 shows that public school students placed more importance on "Travel outside the United States" than private school students.

Table 67. Importance of personal time use in adulthood for nonrural and rural students

\begin{tabular}{|c|c|c|c|c|c|c|c|}
\hline \multirow{2}{*}{$\begin{array}{l}\text { Personal } \\
\text { time factors }\end{array}$} & \multicolumn{2}{|c|}{$\mathbf{M}$} & \multicolumn{2}{|l|}{$S D$} & \multicolumn{2}{|l|}{$\mathbf{N}$} & \multirow[b]{2}{*}{$t$} \\
\hline & Nonrural & $\overline{\text { Rural }}$ & Nonrural & Rural & Nonrural & $\overline{\text { Rural }}$ & \\
\hline \multicolumn{8}{|l|}{ Travel to places outside } \\
\hline the United States & $1.16^{*}$ & $1.24 *$ & 0.44 & 0.49 & 518 & 328 & 2.35 \\
\hline Staying healthy & 1.92 & 1.94 & 0.67 & 0.68 & 518 & 327 & 0.50 \\
\hline Enjoying my spare time & 1.16 & 1.14 & 0.58 & 0.39 & 515 & 325 & -0.62 \\
\hline
\end{tabular}

${ }^{2}$ Scale: $1=$ Very important, $2=$ Somewhat important, $3=$ Not important.

${ }^{*} \underline{p}<.05$. 
Table 68. Importance of personal time use in adulthood for private and public school students ${ }^{2}$

\begin{tabular}{|c|c|c|c|c|c|c|c|}
\hline \multirow{2}{*}{$\begin{array}{l}\text { Personal } \\
\text { time factors }\end{array}$} & \multicolumn{2}{|c|}{$\mathrm{M}$} & \multicolumn{2}{|c|}{$S D$} & \multicolumn{2}{|c|}{$\mathbf{N}$} & \multirow[b]{2}{*}{ t } \\
\hline & Private & Public & Private & Public & Private & Public & \\
\hline \multicolumn{8}{|l|}{ Travel to places outside } \\
\hline the United States & $2.19 *$ & $1.97 *$ & 0.75 & 0.73 & 198 & 652 & -3.58 \\
\hline Staying healthy & 1.19 & 1.23 & 0.46 & 0.49 & 198 & 652 & 0.84 \\
\hline Enjoying my spare time & 1.28 & 1.26 & 0.50 & 0.53 & 198 & 653 & -0.42 \\
\hline
\end{tabular}

${ }^{2}$ Scale: $1=$ Very important, $2=$ Somewhat important, $3=$ Not important.

${ }^{*} \underline{\mathrm{p}}<.05$.

\section{Personal perceptions}

The personal qualities of rural and nonrural students is shown in Table 69. The means for the four personal qualities of "I am dependable, I am optimistic about the future, I make sacrifices today to benefit my future, and I put forth the necessary effort to reach a goal" were very similar and not statistically different.

Table 69. Personal qualities of students residing in town and the country

\begin{tabular}{|c|c|c|c|c|c|c|c|}
\hline \multirow{2}{*}{$\begin{array}{l}\text { Personal } \\
\text { qualities }\end{array}$} & \multicolumn{2}{|c|}{$\mathbf{M}$} & \multicolumn{2}{|l|}{$\mathrm{SD}$} & \multicolumn{2}{|l|}{$\mathbf{N}$} & \multirow[b]{2}{*}{$t$} \\
\hline & Nonrural & Rural & Nonrural & Rural & Nonrural & Rural & \\
\hline I am dependable. & 1.71 & 1.70 & 0.73 & 0.77 & 516 & 327 & -0.17 \\
\hline I put forth necessary effort. & 1.99 & 1.94 & 0.79 & 0.77 & 516 & 327 & -0.95 \\
\hline I am optimistic. & 1.93 & 1.97 & 0.80 & 0.85 & 518 & 327 & 0.69 \\
\hline $\begin{array}{l}\text { I am willing to sacrifice } \\
\text { for my future. }\end{array}$ & 2.23 & 2.15 & 0.90 & 0.84 & 519 & 328 & 1.18 \\
\hline
\end{tabular}

${ }^{2}$ Scale: 1 =Strongly agree, 2 =Agree, 3 =Don't know, $4=$ Disagree, $5=$ Strongly disagree. 
The means for the same qualities were examined for private and public schools, and the results are presented in Table 70. The students in the public schools reported greater agreement with the dependent variable "I am dependable" than did the students in the private schools. The means were significantly different which was determined by an independent t-test.

Table 70. Personal qualities of students from private and public schools ${ }^{2}$

\begin{tabular}{|c|c|c|c|c|c|c|c|}
\hline \multirow{2}{*}{$\begin{array}{l}\text { Personal } \\
\text { qualities }\end{array}$} & \multicolumn{2}{|c|}{$\mathrm{M}$} & \multicolumn{2}{|c|}{ SD } & \multicolumn{2}{|c|}{$\mathbf{N}$} & \multirow[b]{2}{*}{$t$} \\
\hline & Private & Public & Private & Public & Private & Public & \\
\hline I am dependable. & $1.81 *$ & $1.68^{*}$ & 0.83 & 0.72 & 197 & 649 & -2.11 \\
\hline I put forth necessary effort. & 1.99 & 1.96 & 0.83 & 0.77 & 196 & 650 & 0.50 \\
\hline I am optimistic. & 1.93 & 1.96 & 0.79 & 0.83 & 196 & 652 & 0.43 \\
\hline $\begin{array}{l}\text { I am willing to sacrifice } \\
\text { for my future. }\end{array}$ & 2.27 & 2.18 & 0.79 & 0.90 & 198 & 652 & -1.35 \\
\hline
\end{tabular}

${ }^{2}$ Scale: $1=$ Strongly agree, $2=$ Agree, $3=$ Don't know, $4=$ Disagree, $5=$ Strongly disagree. ${ }^{*} \underline{p}<.05$.

\section{Parental perceptions}

The parental qualities reported by the students are reported in Table 71 . There were significant differences between the students who resided in town in either a house or an apartment and the students who resided in the country on an acreage, small farm, or large farm. The rural students reported their parents more positively as a role model than the students who resided in town. The students who resided in town reported on the dependent variable "My parents think going to college is important" more strongly agreed with the statement than their rural counterparts. The dependent variable, "My parents like my school, " was significantly more positive for the rural students than the nonrural students. The students from the rural areas 
Table 71. Parental qualities of students living in the country and in town

Parental qualities

$\frac{M}{\text { Nonrural Rural }} \frac{S D}{\text { Nonrural Rural }} \frac{N}{\text { Nonrural Rural }}$

My parents are positive

role models.

My parents think going to college is important. My parents like my school.
$1.77^{*}$

$1.62 *$

0.92

0.71

$1.55 *$

$2.12 *$

0.79

1.68*

1.01

0.90

0.88

1.99*

1.01

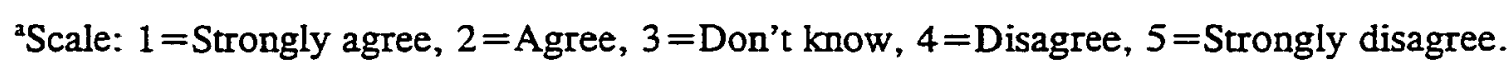
$*_{p}<.05$.

reported that their parents liked their school better than the parents of the students who resided in town.

The same dependent variables were analyzed for the private and public schools. Table 72 shows that the means were significantly different for the three variables analyzed. Students in private schools reported that they more strongly agreed that their parents were more positive role models than the students from the public schools, but students in the public schools felt more strongly that their parents were more positive about them attending college after high school. The private high school students reported more strongly that their parents had a more positive image of their school than did the parents of public school students.

\section{Family perceptions}

The family concerns that may affect a successful adulthood expressed by the students from nonrural and rural areas are reported in Table 73. The dependent variable, "Find the right person to marry," was significantly different between the nonrural and rural respondents. The 
Table 72. Parental qualities of students living in private and public schools ${ }^{a}$

Parental

qualities

$\frac{\mathrm{M}}{\text { Private }}$ Public $\frac{\mathrm{SD}}{\text { Private Public }} \frac{\mathrm{N}}{\text { Private Public } t}$

My parents are positive role models.

1.59

$1.75^{*}$

0.76

0.87

198

$651-2.59$

My parents think going to

college is important.

$1.69 * * \quad 1.57 * *$

0.88

0.82

$0.84 \quad 0.98$

198

$\begin{array}{ll}652 & -1.73\end{array}$

My parents like my school.

$1.75^{*}$

$2.17^{*}$

197

$\begin{array}{ll}650 & 5.97\end{array}$

${ }^{2}$ Scale: $1=$ Strongly agree, $2=$ Agree, $3=$ Don't know, $4=$ Disagree, $5=$ Strongly disagree.

$* \mathrm{p}<.05$.

$* * \mathrm{p}<.01$.

Table 73. Family concerns affecting a successful adulthood of nonrural and rural students ${ }^{\mathrm{a}}$

Family concerns

\section{$\frac{\mathrm{M}}{\text { Nonrural Rural }} \frac{\mathrm{SD}}{\text { Nonrural Rural }}$}

$\frac{N}{\text { Nonrural Rural }}$

Find right person to marry

Live close to parents and relatives

Raising a family

$1.33^{*}$

1.24*

.60

.53

520

$\begin{array}{ll}327 & -2.44\end{array}$

1.98

1.92

1.40

1.39

.60

1.40

.61

1.39

518

$\begin{array}{ll}328 & -1.57\end{array}$

$519 \quad 328-.11$

${ }^{2}$ Scale: 1 =Very important, $2=$ Somewhat important, $3=$ Not important.

${ }^{*} \mathrm{p}<.05$.

rural students expressed greater importance for "Find the right person to marry" than the nonrural students.

The same dependent variables of family concerns affecting a successful adulthood were examined for the private and public schools. The data are reported in Table 74. There were no 
Table 74. Family concerns affecting a successful adulthood of students from private and public schools $^{2}$

Family

concerns
$\frac{\mathrm{M}}{\text { Private }}$ Public $\frac{\mathrm{SD}}{\text { Private Public }} \frac{\mathrm{N}}{\text { Private Public } \mathrm{t}}$

$\begin{array}{llll}1.24 & 1.32 & .53 & .58\end{array}$

.58

198

652

1.66

Live close to parents and relatives

1.93

1.97

1.41

.59

.56

.61

.61

197

652

$198 \quad 652$

Raising a family

1.34

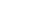

${ }^{2}$ Scale: $1=$ Very important, 2 =Somewhat important, $3=$ Not important.

significant differences for the dependent variables between the private and public school students. The variable, "Find the right person to marry," was reported as being the most important.

\section{Religious desires}

Tables 75 and 76 show the importance of two dependent variables associated with religious factors in the future adulthood of high school seniors. The dependent variables were examined for rural and nonrural students and for private and public school students. The means of the rural students and the nonrural students for the dependent variable, "Live near a church of my faith," were statistically different, but the dependent variable, "Have a spiritually fulfilling life," was not statistically different between the two groups. Rural students expressed more importance to living near a church of their faith than the nonrural students.

The means of the two dependent variables for the private and the public school students were significantly different for both variables. The private school students placed more importance on "Live near a church of my faith" and "Have a spiritually fulfilling life" than students from the public schools. 
Table 75. Importance of religious desires in adulthood for rural and nonrural students ${ }^{2}$

\begin{tabular}{|c|c|c|c|c|c|c|c|}
\hline \multirow{2}{*}{$\begin{array}{l}\text { Religious } \\
\text { desires }\end{array}$} & \multicolumn{2}{|c|}{$\mathbf{M}$} & \multicolumn{2}{|l|}{$\mathrm{SD}$} & \multicolumn{2}{|l|}{$\mathbf{N}$} & \multirow[b]{2}{*}{$\mathrm{t}$} \\
\hline & Nonrural & Rural & Nonrural & Rural & Nonrural & Rural & \\
\hline \multicolumn{8}{|l|}{ Live near a church of } \\
\hline my faith & $1.77 *$ & $1.57^{*}$ & 0.78 & 0.69 & 513 & 320 & -3.78 \\
\hline \multicolumn{8}{|l|}{ Have a spiritually } \\
\hline fulfilling life & 1.52 & 1.45 & 0.63 & 0.68 & 198 & 652 & -1.47 \\
\hline
\end{tabular}

${ }^{2}$ Scale: 1 = Very important, 2 =Somewhat important, $3=$ Not important. ${ }^{*} \mathrm{p}<.05$.

Table 76. Importance of religious desires in adulthood for private and public school students ${ }^{\mathbf{a}}$

\begin{tabular}{|c|c|c|c|c|c|c|c|}
\hline \multirow{2}{*}{$\begin{array}{l}\text { Religious } \\
\text { desires }\end{array}$} & \multicolumn{2}{|c|}{$\mathbf{M}$} & \multicolumn{2}{|c|}{ SD } & \multicolumn{2}{|c|}{$\mathbf{N}$} & \multirow[b]{2}{*}{$\mathrm{t}$} \\
\hline & Private & Public & Private & Public & Private & Public & \\
\hline $\begin{array}{l}\text { Live near a church of } \\
\text { my faith }\end{array}$ & $1.29 *$ & $1.82 *$ & 0.57 & 0.76 & 196 & 640 & 10.47 \\
\hline $\begin{array}{l}\text { Have a spiritually } \\
\text { fulfilling life }\end{array}$ & $1.29 *$ & $1.56^{*}$ & 0.63 & 0.68 & 198 & 652 & 5.12 \\
\hline
\end{tabular}

${ }^{2}$ Scale: 1 = Very important, 2 =Somewhat important, $3=$ Not important.

${ }^{*} \mathrm{p}<.05$.

\section{Future Educational Aspirations}

\section{Educational intent}

Table 77 shows that $91.8 \%$ of the seniors who lived in a house in town were likely to continue their education (combined "Definitely attend" and "Likely attend"). The rural residents also planned to continue their education. Ninety-one and two-tenths percent of those who lived on an acreage, $87.9 \%$ of those who lived on a small farm, and $87.8 \%$ of those who lived on a large 
Table 77. Educational aspirations to attend a college, trade, or business school

\begin{tabular}{|c|c|c|c|c|c|c|c|c|c|c|c|}
\hline \multirow[b]{2}{*}{ Location } & \multicolumn{2}{|c|}{$\begin{array}{c}\text { Definitely } \\
\text { attend }\end{array}$} & \multicolumn{2}{|c|}{$\begin{array}{l}\text { Likely } \\
\text { attend }\end{array}$} & \multicolumn{2}{|c|}{ Not sure } & \multicolumn{2}{|c|}{ Not likelv } & \multicolumn{2}{|c|}{$\begin{array}{c}\text { Definitely } \\
\text { not }\end{array}$} & \multirow[b]{2}{*}{ Tota } \\
\hline & $\underline{\mathrm{f}}$ & $\overline{\%}$ & $\overline{\mathrm{f}}$ & $\overline{\%}$ & $\bar{f}$ & $\overline{\%}$ & $\overline{\mathrm{f}}$ & $\%$ & $\underline{\underline{f}}$ & $\%$ & \\
\hline Live in town & 378 & 77.1 & 72 & 14.7 & 22 & 4.5 & 9 & 1.8 & 9 & 1.8 & 490 \\
\hline Apartment in town & 1 & 12.5 & 3 & 37.5 & 2 & 25.0 & 1 & 12.5 & 1 & 12.5 & 8 \\
\hline Acreage & 103 & 70.1 & 31 & 21.1 & 8 & 5.4 & 2 & 1.4 & 3 & 2.0 & 147 \\
\hline Small farm & & & & & & & & & & & \\
\hline ( $<400$ acres) & 97 & 73.5 & 19 & 14.4 & 10 & 7.6 & 3 & 3.3 & 3 & 2.3 & 132 \\
\hline Large farm & & & & & & & & & & & \\
\hline (>400 acres) & 55 & 74.3 & 10 & 13.5 & 2 & 2.7 & 2 & 2.7 & 5 & 6.8 & 74 \\
\hline Missing & & & & & & & & & & & 2 \\
\hline Total & 634 & 74.9 & 135 & 15.9 & 44 & 5.2 & 17 & 2.0 & 21 & 2.5 & 853 \\
\hline
\end{tabular}

farm reported that they would "Definitely attend" or would "Likely attend" a college, university, trade, or business school. Ninety and eight-tenths percent of all the seniors in AEA 4 reported that they would attend a college, trade, or business school.

Table 78 shows that $72 \%$ of seniors who lived in the countryside were definitely planning to attend a college, university, or trade school compared to $76.3 \%$ of seniors who live in town. If

Table 78. Educational aspirations of rural and nonrural residents

\begin{tabular}{|c|c|c|c|c|c|c|c|c|c|c|c|}
\hline & \multicolumn{2}{|c|}{$\begin{array}{l}\text { Definitely } \\
\text { attend } \\
\end{array}$} & \multicolumn{2}{|c|}{$\begin{array}{l}\text { Likely } \\
\text { attend }\end{array}$} & \multicolumn{2}{|c|}{ Not sure } & \multicolumn{2}{|c|}{ Not likely } & \multicolumn{2}{|c|}{$\begin{array}{c}\text { Definitely } \\
\text { not }\end{array}$} & \multirow[b]{2}{*}{ Total } \\
\hline & $\underline{\underline{f}}$ & $\%$ & $\underline{f}$ & $\%$ & $\underline{f}$ & $\%$ & $\underline{\mathbf{f}}$ & $\%$ & $\underline{f}$ & $\%$ & \\
\hline Nonrural & 397 & 76.3 & 77 & 14.8 & 26 & 5.0 & 10 & 1.9 & 10 & 1.9 & 520 \\
\hline $\begin{array}{l}\text { Rural } \\
\text { Missing } \\
\text { Total }\end{array}$ & 237 & 72.0 & 57 & 17.3 & 17 & 5.2 & 7 & 2.1 & 11 & 3.3 & $\begin{array}{r}329 \\
4 \\
853\end{array}$ \\
\hline
\end{tabular}


the "Definitely attend" and "Likely attend" groups are combined, $91.1 \%$ of the nonrural and $89.3 \%$ of the rural students planned to attend a college, university, trade, or business school after high school.

Table 79 shows the same variable for private and public school students. There were no statistically significant differences noted at $\mathrm{Q}<.05$, but there were differences between the public and private school students $(\underline{p}<.06)$. Table 80 shows the same variable for rural and nonrural students. No statistically significant difference was noted between nonrural and rural students.

Table 79. Frequencies of educational aspirations of private and public school students

\begin{tabular}{|c|c|c|c|c|c|c|c|c|c|c|c|}
\hline & \multicolumn{2}{|c|}{$\begin{array}{c}\text { Definitely } \\
\text { attend }\end{array}$} & \multicolumn{2}{|c|}{$\begin{array}{l}\text { Likely } \\
\text { attend } \\
\end{array}$} & \multicolumn{2}{|c|}{ Not sure } & \multicolumn{2}{|c|}{ Not likely } & \multicolumn{2}{|c|}{$\begin{array}{c}\begin{array}{c}\text { Definitely } \\
\text { not }\end{array} \\
\end{array}$} & \multirow[b]{2}{*}{ Total } \\
\hline & $\underline{f}$ & $\%$ & $\underline{\mathbf{f}}$ & $\%$ & $\underline{f}$ & $\%$ & $\underline{\mathbf{f}}$ & $\%$ & $\underline{f}$ & $\%$ & \\
\hline Private & 135 & 68.2 & 41 & 20.7 & 9 & 4.5 & 6 & 3.0 & 7 & 3.5 & 198 \\
\hline Public & 500 & 76.5 & 94 & 14.4 & 35 & 5.4 & 11 & 1.7 & 14 & 2.1 & 654 \\
\hline
\end{tabular}

Table 80. Means of educational aspirations of private and public school students and rural and nonrural students ${ }^{a}$

\begin{tabular}{lllll}
\hline & M & SD & N & t \\
\hline Private & 1.53 & 0.98 & 198 & -1.87 \\
Public & 1.39 & 0.84 & 654 & \\
Nonrural & 1.38 & 0.83 & 520 & 1.45 \\
Rural & 1.47 & 0.94 & 329 & \\
& & & & \\
\hline
\end{tabular}
not.

aScale: $1=$ Definitely attend, $2=$ Likely attend, $3=$ Not sure, $4=$ Not likely, $5=$ Definitely 
Table 81 shows the type of education the students indicated they would pursue after high school. The private school students were significantly different from the public school students in the type of education they planned to pursue. A greater percentage of the private school students (7.1\%) did not plan to continue their education. "No additional education planned, trade, technical school, business college," and "2-year community college" intention were combined, and $41.6 \%$ of the private school students were included compared to $31.4 \%$ of the public school students. The nonrural and rural students showed no significant differences.

Table 81 . Type of education the students planned to pursue after high school

\begin{tabular}{|c|c|c|c|c|c|c|c|c|c|c|c|}
\hline & \multicolumn{2}{|c|}{$\begin{array}{c}\text { No } \\
\text { additional } \\
\text { education } \\
\text { planned } \\
\end{array}$} & \multicolumn{2}{|c|}{$\begin{array}{l}\text { Trade, } \\
\text { tech } \\
\text { school, } \\
\text { business } \\
\text { college }\end{array}$} & \multicolumn{2}{|c|}{$\begin{array}{c}\text { 2-year } \\
\text { community } \\
\text { college }\end{array}$} & \multicolumn{2}{|c|}{$\begin{array}{c}\text { 2-year } \\
\text { community } \\
\text { college, } \\
\text { then 4-year } \\
\text { college or } \\
\text { university }\end{array}$} & \multicolumn{2}{|c|}{$\begin{array}{l}\text { 4-year } \\
\text { college or } \\
\text { university }\end{array}$} & \multirow[b]{2}{*}{ Total } \\
\hline & $\underline{f}$ & $\%$ & $\underline{f}$ & $\%$ & $\underline{f}$ & $\%$ & $\underline{\mathbf{f}}$ & $\%$ & $\underline{f}$ & $\%$ & \\
\hline Private* & 14 & 7.1 & 25 & 12.6 & 44 & 22.2 & 13 & 6.6 & 102 & 51.5 & 198 \\
\hline Public* & 22 & 3.4 & 56 & 8.6 & 127 & 19.4 & 88 & 13.5 & 360 & 55.1 & 653 \\
\hline Nonrural & 23 & 4.4 & 48 & 9.2 & 95 & 18.3 & 69 & 13.3 & 284 & 54.7 & 519 \\
\hline Rural & 13 & 4.0 & 33 & 10.0 & 74 & 22.5 & 32 & 9.7 & 177 & 53.8 & 329 \\
\hline
\end{tabular}

$* \chi^{2}(4, \mathrm{~N}=851)=14.60, \mathrm{p}<.05$

Table 82 shows that a greater percentage of females than males had aspirations to continue their education. "Definitely attend" and "Likely attend" were combined, and $85.4 \%$ of the males and $94.5 \%$ of the females reported that they would attend a college, university, or trade school.

Table 83 shows the educational aspirations of students who took agriculture courses. Eighty-three and eight-tenths percent of the students who took an agriculture course indicated that 
Table 82. Frequencies of males and females for their plans to attend a college, university, or trade school

\begin{tabular}{|c|c|c|c|c|c|c|c|c|c|c|}
\hline & \multicolumn{2}{|c|}{$\begin{array}{c}\text { Definitely } \\
\text { attend } \\
\end{array}$} & \multicolumn{2}{|c|}{$\begin{array}{l}\text { Likely } \\
\text { attend }\end{array}$} & \multicolumn{2}{|c|}{$\begin{array}{l}\text { Not } \\
\text { sure }\end{array}$} & \multicolumn{2}{|c|}{$\begin{array}{c}\text { Not } \\
\text { likely }\end{array}$} & \multicolumn{2}{|c|}{$\begin{array}{c}\text { Definitely } \\
\text { not }\end{array}$} \\
\hline & $\underline{f}$ & $\%$ & $\underline{f}$ & $\%$ & $\underline{f}$ & $\%$ & $\underline{\mathbf{f}}$ & $\%$ & $\underline{\mathbf{f}}$ & $\%$ \\
\hline Male & 307 & 68.8 & 83 & 18.6 & 25 & 5.6 & 13 & 2.9 & 18 & 4.0 \\
\hline Female & 327 & 81.8 & 51 & 12.7 & 18 & 4.5 & 4 & 1.0 & 3 & 0.7 \\
\hline
\end{tabular}

Table 83. Educational aspirations of those who took agriculture courses and those who did not

\begin{tabular}{|c|c|c|c|c|c|c|c|c|c|c|c|}
\hline \multirow{2}{*}{$\begin{array}{l}\text { Indication of } \\
\text { further education }\end{array}$} & \multicolumn{2}{|c|}{$\begin{array}{c}\text { Definitely } \\
\text { attend }\end{array}$} & \multicolumn{2}{|c|}{$\begin{array}{l}\text { Probably } \\
\text { attend }\end{array}$} & \multicolumn{2}{|c|}{ Not sure } & \multicolumn{2}{|c|}{ Not likely } & \multicolumn{2}{|c|}{$\begin{array}{c}\begin{array}{c}\text { Definitely } \\
\text { not }\end{array} \\
\end{array}$} & \multirow[b]{2}{*}{ Tota } \\
\hline & $\underline{\mathbf{f}}$ & $\%$ & $\underline{f}$ & $\%$ & $\underline{\mathbf{f}}$ & $\%$ & $\underline{\mathrm{f}}$ & $\%$ & $\underline{f}$ & $\%$ & \\
\hline Took agriculture & & & & & & & & & & & \\
\hline $\begin{array}{c}\text { course } \\
\text { No agriculture }\end{array}$ & 168 & 68.0 & 39 & 15.8 & 22 & 8.9 & 8 & 3.2 & 10 & 4.0 & 247 \\
\hline $\begin{array}{l}\text { course taken } \\
\text { Missing }\end{array}$ & 466 & 77.3 & 95 & 15.8 & 22 & 3.6 & 9 & 1.5 & 11 & 1.8 & $\begin{array}{r}603 \\
3\end{array}$ \\
\hline Total & 635 & 74.5 & 135 & 15.8 & 44 & 5.2 & 17 & 2.0 & 21 & 2.5 & 853 \\
\hline
\end{tabular}

they would "Probably attend" or "Definitely attend" a college, university, or trade school after high school. Ninety-three and one-tenth percent of students who had not taken an agriculture course indicated that they would continue their education.

Table 84 shows that the means for the likelihood of continuing their education were significantly different. The students who had not taken an agriculture course were more likely to continue their education. 
Table 84. Means and standard deviations of likelihood of continuing their education for students who took agriculture courses and those who did not ${ }^{2}$

\begin{tabular}{lrrrr}
\hline & M & SD & N & t \\
\hline & & & & \\
Took agriculture course*** & 1.60 & 1.05 & 247 & 3.34 \\
No agriculture course taken & & & \\
& 1.35 & .78 & 603 & \\
\hline
\end{tabular}

${ }^{2}$ Scale: $1=$ Definitely attend, $2=$ Likely attend, $3=$ Not sure, $4=$ Not likely, $5=$ Definitely not attend.

$* * * \mathrm{p}<.001$.

\section{Program of study}

The students were given a blank on the questionnaire to list their intended program of study. Their comments were categorized as much as possible while trying to maintain the integrity of their program aspirations. There were sixty-three initial categories. The categories that had a frequency of less than 1 percent were combined when possible. Table 85 shows the frequencies of the programs of study. Business/Marketing/Accounting and Management was the most frequently identified future program of study (15.7\%) followed by education ( $8.4 \%)$, Health, Pre-Med, Nursing, Chiropractor (7.6\%), and Agriculture (6.4\%). If the two health related programs of study are combined, they account for $12.8 \%$ of the student intentions for future program of study and would be ranked second. The original data for program of study are located in Table 115, and Table 116 shows how the data were categorized for Table 85. (Tables 115 and 116 were placed in Appendix F.)

Tables 86 and 87 show the frequencies for intended program of study for private and public school students and for rural and nonrural students. The top-ranked intended program of study was the "Business/Marketing/Accounting/Management" area for both groups of students. The private school students had a greater percentage of students enrolling in the "Health-Pre- 
Table 85. Frequencies of the expected programs of study $(N=747)$

Area of study

Agriculture

Arts, Design, Graphic Design, Music

Aviation

Biology/Wildlife Management/Environmental Studies

Business/Marketing/Accounting/Management

Computer related fields

Construction, Carpentry, Electrician

Education, all types

Engineering, Architecture, Mathematics

English, Communications, Journalism, Pre-Sem

General

Health-Pre-Med, Nursing, Chiropractor

Health Support/Physical Therapy/Athletic Trainer

Law Enforcement

Mechanic, Auto Body, Diesel

Military

Personal Care/Cosmetology/Child Care/Massage

Physics, Chemistry

Political Science, Pre-Law, Foreign Language

Psychology, Social Work

Secretarial

Two-year Associate, Technical School

Undecided $\underline{f}$

$\%$

Rank

\begin{tabular}{rrr}
48 & 6.4 & \\
33 & 4.4 & 10 \\
4 & 0.5 & 23 \\
24 & 3.2 & $15 / 16$ \\
117 & 15.7 & 1 \\
34 & 4.6 & 9 \\
25 & 3.3 & 14 \\
63 & 8.4 & 2 \\
37 & 5.0 & 7 \\
32 & 4.3 & 11 \\
22 & 2.9 & 17 \\
57 & 7.6 & 3 \\
39 & 5.2 & $5 / 6$ \\
18 & 2.4 & 19 \\
27 & 3.6 & 12 \\
6 & 0.8 & $21 / 22$ \\
24 & 3.2 & $15 / 16$ \\
6 & 0.8 & $21 / 22$ \\
19 & 2.5 & 18 \\
39 & 5.2 & $5 / 6$ \\
9 & 1.2 & 20 \\
26 & 3.5 & 13 \\
38 & 5.0 & 8 \\
& & \\
\hline & &
\end{tabular}

Med, Nursing, Chiropractor" program of study than public school students, and the area ranked second for students from private schools. "Education" as a program of study ranked second for the students from the public schools. The categories that had a $2.5 \%$ or greater difference between private and public school students were "Arts, Design, Graphic Design, Music," and "Biology/Wildlife Management/Environmental Studies" and "Education" which were preferred by the public school students as a program of study. A greater percentage of the private school students had an interest in the programs of study of "Computer related fields" and "English, Communications, Journalism, Pre-Sem," and "Health-Pre-Med, Nursing, Chiropractor." 
Table 86. Frequencies of the expected programs of study of students in private and public schools $(N=747)$

Area of study

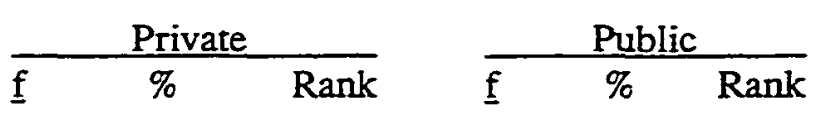

Agriculture

Arts, Design, Graphic Design, Music

$\begin{array}{rrrrrr}14 & 7.9 & 3 & 34 & 6.0 & 3 \\ 4 & 2.2 & 7-8 & 29 & 5.1 & 9 \\ 0 & 0.0 & 23 & 4 & 0.7 & 23\end{array}$

Aviation

Biology/Wildlife Management/

Environmental Studies

$\begin{array}{rrrrrr}5 & 2.8 & 14-16 & 19 & 5.3 & 13-14 \\ 25 & 14.0 & 1 & 92 & 16.2 & 1 \\ 12 & 6.7 & 4-5 & 22 & 3.9 & 10 \\ 5 & 2.8 & 14-16 & 20 & 3.5 & 11-12 \\ 8 & 4.5 & 7-8 & 55 & 9.7 & 2 \\ 7 & 3.9 & 10-13 & 30 & 5.3 & 7-8\end{array}$

Engineering, Architecture, Mathematics

English, Communications, Journalism,

Pre-Sem

General

Health-Pre-Med, Nursing, Chiropractor

Health Support/Physical Therapy/

Athletic Trainer

Law Enforcement

Mechanic, Auto Body, Diesel

Military

Personal Care/Cosmetology/Child Care/

Massage

Physics, Chemistry

Political Science, Pre-Law, Foreign

Language

Psychology, Social Work

Secretarial

Two-year Associate, Technical School

Undecided

$\begin{array}{rrrrrr}12 & 6.7 & 4-5 & 20 & 3.5 & 11-12 \\ 4 & 2.2 & 17-18 & 18 & 3.1 & 15-17 \\ 24 & 13.5 & 2 & 33 & 5.8 & 4\end{array}$

$\begin{array}{rrrrrr}7 & 3.9 & 10-13 & 34 & 5.4 & 5-6 \\ 5 & 2.8 & 14-16 & 13 & 2.3 & 19 \\ 8 & 4.5 & 7-9 & 19 & 3.3 & 13-14 \\ 1 & 0.6 & 21-22 & 5 & 0.9 & 21-22 \\ & & & & & \\ 6 & 3.4 & 10-13 & 18 & 3.2 & 15-17 \\ 1 & 0.6 & 21-22 & 5 & 0.9 & 21-22 \\ & & & & & \\ 2 & 1.1 & 20 & 17 & 3.0 & 18 \\ 9 & 5.1 & 6 & 30 & 5.3 & 7-8 \\ 3 & 1.7 & 19 & 6 & 3.6 & 20 \\ 8 & 4.5 & 7-9 & 18 & 3.2 & 15-17 \\ 7 & 3.9 & 10-13 & 31 & 5.3 & 5-6\end{array}$

Totals

178

569 
Table 87. Frequencies of the expected programs of study of nonrural and rural students $(N=745)$

Area of study

$\frac{\text { Nonrural }}{\text { f } \quad \text { Rank }}$

$\frac{\text { Rural }}{\mathrm{f} \quad \text { Rank }}$

Agriculture

18

3.9

9-11

30

10.5

2

Arts, Design, Graphic Design, Music

17

3.7

12-14

16

5.6

6-7

Aviation

Biology/Wildlife Management/

Environmental Studies

4

0.9

$20-21$

$0 \quad 0.0$

23

Business/Marketing/Accounting/Management

Computer related fields

12

86

2.6

18.7

Construction, Carpentry, Electrician

Education, all types

Engineering, Architecture, Mathematics

$18 \quad 3.9$

18

$8 \quad 12$

$4.2 \quad 11-12$

13

2.8

9-11

12
31

10.9

1

13

17

$5.6 \quad 6-7$

45

9.8

17

16

$4.2 \quad 11-12$

17

3.7

12-14

18

$6.3 \quad 5$

English, Communications, Journalism,

Pre-Sem

\section{9}

4.1

7-8

19

6.7

4

General

Health-Pre-Med, Nursing, Chiropractor

3.7

12-14

13

$4.6 \quad 10$

31

6.7

3

5

1.8

19

Health Support/Physical Therapy/

26

9.1

Military

Athletic Trainer

Law Enforcement

24

5.2

$$
\text { 5-6 }
$$

Mechanic, Auto Body, Diesel

Personal Care/Cosmetology/Child Care/

Massage

Physics, Chemistry

Political Science, Pre-Law, Foreign
Language

Psychology, Social Work

Secretarial

Two-year Associate, Technical School

Undecided
$11 \quad 2.4$

$19 \quad 4.1$

$3 \quad 0.7$

18

4

\section{9}

0.9

15

24

3

15

27

$4.7 \quad 15-16$

5.2

0.7

$5-6$

$15-16$

3.3

5.9

15-16

4

4

460

\section{5}

5.3

8-9

7

2.5

$\begin{array}{lll}8 & 2.8 & 15\end{array}$

16

$3 \quad 1.1 \quad 21$

Totals $\begin{array}{lll}6 & 2.1 & 17-18\end{array}$

$\begin{array}{lll}2 & 0.7 & 22\end{array}$

$\begin{array}{lll}4 & 1.4 & 20\end{array}$

$\begin{array}{lll}15 & 5.3 & 17-18\end{array}$

$\begin{array}{lll}6 & 2.1 & 14\end{array}$

$\begin{array}{lll}10 & 3.5 & 14\end{array}$

$\begin{array}{lll}11 & 3.9 & 13\end{array}$ 
The nonrural and rural students ranked the "Business/Marketing/Accounting/Management" category as their number one choice of program of study, the same as the private and public school students. "Agriculture" was selected as the second-ranked intended program of study for the rural students, and "Education" was ranked second as the intended program of study by the nonrural students. The categories that had a $2.5 \%$ or greater difference between nonrural and rural students were "Agriculture" and "Engineering, Architecture, Mathematics," which were preferred by the rural students. A greater percentage of the nonrural students had an interest in the programs of study of "Business/Marketing/Accounting/Management" and "Education" and "Political Science, Pre-Law, Foreign Language."

Table 88 shows the frequencies of the program of study for males and females. "Business/Marketing/Accounting/Management was the number one ranked intended program of srudy for males and females. "Agriculture" ranked second for the males, and "Education" ranked second for the females. A greater percentage of the females planned to enter the health field. Both health fields had a greater percentage of females who intended to study in that area, and when the percentages for the two fields were combined, $17.8 \%$ of the females intended to enroll in some area of the health field, and $8 \%$ of the males planned to pursue a program of study in the health field.

The categories that had $2.5 \%$ or greater between the males and the females were the categories of "Education; Health-Pre-Med, Nursing, Chiropractor; Health Support/Physical Therapy/Athletic Trainer; Personal Care/Cosmetology/Child Care/Massage;" and "Psychology, Social Work." The categories where the male percentage exceeded $2.5 \%$ above the females were the categories of "Agriculture; Business/Marketing/Accounting/Management; Construction, Carpentry, Electrician; Engineering, Architecture, Mathematics; Law Enforcement;" and "Mechanic, Auto Body, Diesel." 
Table 88. Frequencies of the expected programs of study based on gender $(N=745)$

Area of study

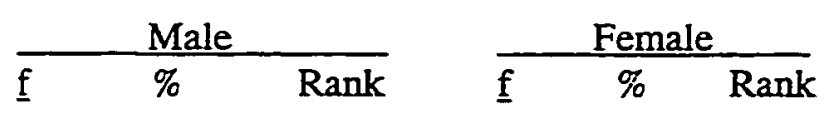

Agriculture

32

Arts, Design, Graphic Design, Music

Aviation

Biology/Wildlife Management/

Environmental Studies

Business/Marketing/Accounting/Management

Computer related fields

Construction, Carpentry, Electrician

Education, all types

Engineering, Architecture, Mathematics

English, Communications, Journalism, Pre-Sem

General

Health-Pre-Med, Nursing, Chiropractor

Health Support/Physical Therapy/ Athletic Trainer

Law Enforcement

Mechanic, Auto Body, Diesel

Military

Personal Care/Cosmetology/Child Care/ Massage

Physics, Chemistry

Political Science, Pre-Law, Foreign Language

Psychology, Social Work

Secretarial

Two-year Associate, Technical School

Undecided

Totals

374

$15 \quad 4.0$

$4 \quad 1.0$

$16 \quad 4.3$

$65 \quad 17.4$

$24 \quad 6.4$

$23 \quad 6.1$

$19 \quad 5.1$

$31 \quad 8.3$

$\begin{array}{ll}14 & 3.7\end{array}$

$12 \quad 3.2$

$18 \quad 4.8$

$12 \quad 3.2$

$14 \quad 3.7$

$23 \quad 6.1$

20.5

$0 \quad 0.0$

$5 \quad 1.0$

22-23

19

$9 \quad 2.4$

$6 \quad 1.6$

$0 \quad 0.0$

$12 \quad 3.2$

18

$\begin{array}{rrrr}2 & 16 & 4.3 & 10 \\ 11 & 18 & 4.8 & 8-9 \\ 20 & 0 & 0.0 & 23\end{array}$

$\begin{array}{llll}8 & 8 & 2.2 & 16\end{array}$

$\begin{array}{rrrr}1 & 52 & 14.0 & 1\end{array}$

$\begin{array}{llll}4 & 10 & 2.7 & 12-14\end{array}$

$\begin{array}{rrrr}5-6 & 2 & 0.5 & 21\end{array}$

$\begin{array}{llll}7 & 44 & 11.8 & 2\end{array}$

$\begin{array}{llll}3 & 6 & 1.6 & 17\end{array}$

12-13 18

$4.8 \quad 8-9$

$\begin{array}{llll}14-15 & 10 & 2.7 & 12-14\end{array}$

$\begin{array}{llll}8-9 & 39 & 10.5 & 3\end{array}$

$\begin{array}{rrrr}14-15 & 27 & 7.3 & 5 \\ 12-13 & 4 & 1.1 & 18-20 \\ 5-6 & 4 & 1.1 & 18-20 \\ 21 & 4 & 1.1 & 18-20\end{array}$

$\begin{array}{lll}24 & 6.5 & 6\end{array}$

$\begin{array}{lll}1 & 0.3 & 22\end{array}$

$\begin{array}{lll}10 & 2.7 & 12-14\end{array}$

$\begin{array}{lll}33 & 8.9 & 4\end{array}$

$9 \quad 2.4 \quad 15$

$13 \quad 3.5 \quad 11$

$\begin{array}{lll}20 & 5.4 & 7\end{array}$ 


\section{Degree importance}

Tables 89 and 90 show the importance the students placed on obtaining a two-year or a four-year degree after high school for rural and nonrural students and for private and public school students. Table 89 shows that obtaining a two-year degree was somewhat important but the difference between the nonrural and rural students was not significantly different. There was a difference between the nonrural and rural students on the importance of obtaining a four-year degree. Students living in town expressed more importance to obtaining a four-year degree than the students living in the country.

Table 89. Importance of obtaining a college degree in adulthood for nonrural and rural students ${ }^{\mathrm{a}}$

\begin{tabular}{|c|c|c|c|c|c|c|c|}
\hline \multirow[b]{2}{*}{ Degree type } & \multicolumn{2}{|c|}{ M } & \multicolumn{2}{|c|}{$S D$} & \multicolumn{2}{|l|}{$\mathrm{N}$} & \\
\hline & Nonrural & $\overline{\text { Rural }}$ & Nonrural & Rural & Nonrural & Rural & $t$ \\
\hline Two-year degree & 2.02 & 1.93 & 0.85 & 0.86 & 518 & 328 & -1.43 \\
\hline Four-year degree & $1.60 *$ & $1.77^{*}$ & 0.80 & 0.83 & 520 & 328 & -3.78 \\
\hline
\end{tabular}

${ }^{2}$ Scale: $1=$ Very important, $2=$ Somewhat important, $3=$ Not important. ${ }^{*} \mathrm{p}<.05$.

Table 90 shows no significant difference for the importance of obtaining a two-year degree for students from private and public schools, but there was a significant difference in the importance of obtaining a four-year degree between students from private and public schools. The students from public schools placed significantly more importance on obtaining a four-year degree than the students from the private schools. 
Table 90. Importance of obtaining a college degree in adulthood for private and public school students ${ }^{2}$

\begin{tabular}{|c|c|c|c|c|c|c|c|}
\hline \multirow[b]{2}{*}{ Degree type } & \multicolumn{2}{|c|}{$\mathbf{M}$} & \multicolumn{2}{|c|}{$\mathrm{SD}$} & \multicolumn{2}{|c|}{$N$} & \multirow[b]{2}{*}{$t$} \\
\hline & Private & Public & Private & Public & Private & Public & \\
\hline Two-year degree & 1.99 & 1.98 & 0.87 & 0.85 & 197 & 652 & -0.92 \\
\hline Four-year degree & $1.85^{*}$ & $1.60^{*}$ & 0.84 & 0.80 & 198 & 653 & -3.88 \\
\hline
\end{tabular}

${ }^{2}$ Scale: $1=$ Very important, $2=$ Somewhat important, $3=$ Not important.

${ }^{*} \mathrm{p}<.05$.

\section{Future Occupational Aspirations}

\section{Plans for military}

Table 91 shows that $37.5 \%$ of the seniors who lived in an apartment are likely to enter the military. The "Not likely" and "Definitely not" categories were combined, and $80.3 \%$ of the seniors residing on acreages, $87.9 \%$ of students residing on small farms, and $91.9 \%$ of students living on large farms reported that they were not likely to consider the military as a future occupational aspiration.

A one-way Anova analysis reported in Table 92 shows that the means for seniors who lived in apartments and on acreages were significantiy more inclined to enter the military than those who lived in a house in town or on a small farm or large farm, although the means indicated that they were between "Not sure" and "Not likely" in their intention to enter the military.

\section{Future location to live}

The location factors of where the students wanted to live are the factors listed in Table 93. The means were significantly different for rural and nonrural students for all but one of the 
Table 91. Military intentions of the seniors based on where they lived

\begin{tabular}{|c|c|c|c|c|c|c|c|c|c|c|c|}
\hline \multirow[b]{2}{*}{ Location } & \multicolumn{2}{|c|}{$\begin{array}{l}\text { Definitely } \\
\text { enter }\end{array}$} & \multicolumn{2}{|c|}{$\begin{array}{c}\text { Likely } \\
\text { enter }\end{array}$} & \multicolumn{2}{|c|}{ Not sure } & \multicolumn{2}{|c|}{ Not likely } & \multicolumn{2}{|c|}{$\begin{array}{c}\text { Definitely } \\
\text { not }\end{array}$} & \multirow[b]{2}{*}{ Total } \\
\hline & $\underline{\mathbf{f}}$ & $\%$ & $\underline{f}$ & $\%$ & $\underline{\mathbf{f}}$ & $\%$ & $\underline{\mathbf{f}}$ & $\%$ & $\underline{\underline{\mathrm{f}}}$ & $\%$ & \\
\hline Live in town & 22 & 4.5 & 6 & 1.2 & 26 & 5.3 & 84 & 17.2 & 351 & 71.8 & 489 \\
\hline Apartment in town & 3 & 37.5 & 0 & 0.0 & 0 & 0.0 & 1 & 12.5 & 4 & 50.0 & 8 \\
\hline $\begin{array}{l}\text { Acreage } \\
\text { Small farm }\end{array}$ & 9 & 6.1 & 4 & 2.7 & 16 & 10.9 & 37 & 25.2 & 81 & 55.1 & 147 \\
\hline $\begin{array}{l}\text { (<400 acres) } \\
\text { Large farm }\end{array}$ & 5 & 3.8 & 2 & 1.5 & 9 & 6.8 & 20 & 15.2 & 96 & 72.7 & 132 \\
\hline $\begin{array}{l}\text { Large tarm } \\
\text { (>400 acres) } \\
\text { Missing }\end{array}$ & 3 & 4.1 & 0 & 0.0 & 3 & 4.1 & 17 & 23.0 & 51 & 68.9 & $\begin{array}{r}74 \\
3\end{array}$ \\
\hline Total & 42 & 4.9 & 12 & 1.4 & 54 & 6.4 & 159 & 18.7 & 583 & 68.6 & 853 \\
\hline
\end{tabular}

Table 92. Analysis of variance of students' intentions to enter the military

\begin{tabular}{llrr}
\hline Location & $\mathbf{M}^{\mathrm{b}}$ & $\mathrm{SD}$ & $\mathrm{N}$ \\
\hline & & & \\
\hline & 4.51 & 0.99 & 489 \\
Apartment in town & $3.38^{*}$ & 2.00 & 8 \\
Acreage & $4.20^{*}$ & 1.13 & 147 \\
Small farm & 4.52 & 0.97 & 132 \\
Large farm & 4.53 & 0.91 & 74 \\
\hline
\end{tabular}

${ }^{2}$ Scale: $1=$ Definitely enter, 2 =Likely enter, $3=$ Not sure, $4=$ Not likely, $5=$ Definitely not. ${ }^{\mathrm{b}} \mathrm{F}(4,845)=4.98$.

${ }^{*} \mathrm{D}<.05$ using the Schéffé post hoc test. 
dependent variables, "Live in a small town." The students who lived in rural areas expressed more importance for the factors of "Where I now live," "Live in the country on an acreage or farm," and "Live in a small town." Students who lived in town placed more importance on living in a medium sized or big city than those who lived in town.

The questions were phrased to describe the city sizes. The students were asked how important it was for them to live in a "Big city like Chicago or New York" or in a "Medium city like Sioux Falls or Sioux City." The examples of a medium sized city were examples of close proximity to the students, and the students would have a familiarity with the size designations.

Table 93. Importance of future living location in adulthood for nonrural and rural students ${ }^{2}$

\begin{tabular}{|c|c|c|c|c|c|c|c|}
\hline \multirow{2}{*}{$\begin{array}{l}\text { Future } \\
\text { location }\end{array}$} & \multicolumn{2}{|c|}{$M$} & \multicolumn{2}{|l|}{$\mathrm{SD}$} & \multicolumn{2}{|l|}{$\mathbf{N}$} & \multirow[b]{2}{*}{ t } \\
\hline & Nonrural & Rural & Nonrural & Rural & Nonrural & Rural & \\
\hline $\begin{array}{l}\text { Live where I now live } \\
\text { Live in country on a farm }\end{array}$ & $2.48^{*}$ & $2.30^{*}$ & 0.65 & 0.68 & 520 & 328 & -3.84 \\
\hline or acreage & $2.62 *$ & $2.17^{*}$ & 0.65 & 0.76 & 518 & 328 & -8.83 \\
\hline Live in a small town & 2.37 & 2.32 & 0.66 & 0.66 & 520 & 328 & -0.95 \\
\hline Live in a medium sized city & $2.14^{*}$ & $2.29 *$ & 0.66 & 0.66 & 520 & 327 & 3.23 \\
\hline Live in a big city & $2.53 *$ & $2.63^{*}$ & 0.68 & 0.62 & 520 & 328 & 2.35 \\
\hline
\end{tabular}

${ }^{2}$ Scale: $1=$ Very important, 2 =Somewhat important, $3=$ Not important. ${ }^{*} \mathrm{p}<.05$.

Table 94 shows that private school students expressed more importance to "Live where I now live" in the future than students from public schools. The private school seniors also expressed significantly more importance than public school students to "Living in a big city" in the future than did the seniors in public schools. The other means showed no significant 
difference. The range of the means was closer (2.18-2.66) in Table 94 than the range of Table 93 (1.14-2.63). The rural students in Table 93 expressed the greatest importance on living in the country or on a farm or acreage, and the nonrural students expressed the most importance in living in a medium sized city.

Table 94. Importance of future living location in adulthood for private and public school students ${ }^{\mathrm{a}}$

Future location $\frac{\mathrm{M}}{\text { Private Public }} \frac{\mathrm{SD}}{\text { Private Public }} \frac{\mathrm{N}}{\text { Private Public }} \mathrm{t}$

Live where I now live $2.32 *$ $2.43^{*}$ .69 .66 198 653

Live in country on a farm or acreage

2.40

2.46

.74

.72

197

$\begin{array}{ll}652 & 0.93\end{array}$

Live in a small town

2.30

2.37

.69

.65

198

$653 \quad 1.39$

Live in a medium sized city

2.26

2.18

.67

.66

198

$652-1.58$

Live in a big city

2.54*

$2.66^{*}$

$.60 \quad .67$

$\begin{array}{lll}198 & 653 & -2.48\end{array}$

${ }^{2}$ Scale: $1=$ Very important, $2=$ Somewhat important, $3=$ Not important. ${ }^{*} \underline{p}<.05$.

\section{Pursue a career in agriculture}

Table 95 shows that private and public school students were similar and felt the importance of an agricultural career to be between "Somewhat important" to "Not important." The rural and nonrural students expressed similar importance, and the differences between the nonrural and rural students were significantly different. The rural students indicated more importance to pursuing an agriculturally related career than nonrural students. 
Table 95. Importance of pursuing an agriculturally related career ${ }^{2}$

\begin{tabular}{lllll}
\hline & M & SD & N & t \\
\hline Private & & & & \\
Public & 2.63 & 0.67 & 198 & 0.20 \\
Nonrural** & 2.64 & 0.68 & 653 & \\
Rural** & 2.46 & 0.76 & 328 & -5.04 \\
& 2.75 & 0.75 & 520 & \\
\hline
\end{tabular}

'Scale: 1 = Very important, $2=$ Somewhat important, $3=$ Not important. ${ }^{* *} \underline{p}<.01$.

\section{Potential Barriers to Educational and Occupational Aspirations}

\section{Location barriers}

The future aspirations of students were examined that pertained to the rural location. Table 96 shows that the students perceived all three variables as negligible barriers to their aspirations. The means were all greater than 2 which was the value of "Somewhat of a barrier." The students in the private schools were significantly different than the public school students for the variable "Lack of jobs in my community." The private school students reported this variable as less of a barrier than the public school students.

The same variables were examined for nonrural and rural students. Table 97 shows similar results to the results shown in Table 96. The nonrural and rural students reported similar responses to the variables pertaining to rural location. There were no statistically significant differences between the nonrural and rural student responses. The means indicated that the students did not perceive their rural location as a barrier to their aspirations. 
Table 96. Perceived rural location barriers to future aspirations for private and public school students ${ }^{2}$

\begin{tabular}{|c|c|c|c|c|c|c|c|}
\hline \multirow[b]{2}{*}{ Location barriers } & \multicolumn{2}{|c|}{$\mathbf{M}$} & \multicolumn{2}{|c|}{$\mathrm{SD}$} & \multicolumn{2}{|c|}{$\mathbf{N}$} & \multirow[b]{2}{*}{$\mathrm{t}$} \\
\hline & Private & Public & Private & Public & Private & Public & \\
\hline Lack of jobs in my community & $2.86^{*}$ & $2.64^{*}$ & 2.21 & 0.61 & 198 & 653 & -2.29 \\
\hline $\begin{array}{l}\text { Living in a rural place } \\
\text { No school near my home to }\end{array}$ & 2.72 & 2.67 & 0.54 & 0.59 & 198 & 653 & -1.06 \\
\hline further my education & 2.83 & 2.82 & 0.44 & 0.46 & 198 & 652 & -0.26 \\
\hline
\end{tabular}

${ }^{2}$ Scale: $1=$ Large barrier, 2 =Somewhat of a barrier, $3=$ Not a barrier.

${ }^{*} \mathrm{p}<.05$.

Table 97. Perceived rural location barriers to future aspirations for nonrural and rural students $\mathbf{s}^{\mathbf{a}}$

\begin{tabular}{|c|c|c|c|c|c|c|c|}
\hline \multirow[b]{2}{*}{ Location barriers } & \multicolumn{2}{|l|}{$\mathbf{M}$} & \multicolumn{2}{|c|}{$\mathrm{SD}$} & \multicolumn{2}{|c|}{$\mathbf{N}$} & \multirow[b]{2}{*}{$t$} \\
\hline & Nonrural & Rural & Nonrural & Rural & Nonrural & Rural & \\
\hline Lack of jobs in my community & 2.67 & 2.73 & 0.60 & 1.78 & 520 & 328 & 0.74 \\
\hline Living in a rural place & 2.70 & 2.64 & 0.58 & 0.59 & 520 & 328 & -1.55 \\
\hline $\begin{array}{l}\text { No school near my home to } \\
\text { further my education }\end{array}$ & 2.83 & 2.81 & 0.45 & 0.46 & 519 & 328 & -0.73 \\
\hline
\end{tabular}

ascale: $1=$ Large barrier, 2 =Somewhat of a barrier, $3=$ Not a barrier.

\section{Financial barriers}

The variable "Lack of money for my education" was used to determine if finances were a barrier to student educational aspirations. Tables 98 and 99 show that finances were close to being reported as "Somewhat of a barrier" to private and public school students and to nonrural and rural students, but the groups were not statistically different at $\underline{p}<.05$. 
Table 98. Perceived financial barriers to future educational aspirations for private and public school students ${ }^{2}$

\begin{tabular}{|c|c|c|c|c|c|c|c|}
\hline \multirow[b]{2}{*}{ Financial barrier } & \multicolumn{2}{|c|}{$\mathrm{M}$} & \multicolumn{2}{|c|}{ SD } & \multicolumn{2}{|c|}{$\mathbf{N}$} & \multirow[b]{2}{*}{ t } \\
\hline & Private & Public & Private & Public & Private & $\overline{\text { Public }}$ & \\
\hline Lack money for education & 2.13 & 2.12 & 0.67 & 0.66 & 197 & 652 & 0.50 \\
\hline
\end{tabular}

${ }^{2}$ Scale: $1=$ Large barrier, 2 =Somewhat of a barrier, $3=$ Not a barrier.

Table 99. Perceived financial barriers to future educational aspirations for nonrural and rural students ${ }^{\mathbf{a}}$

\begin{tabular}{|c|c|c|c|c|c|c|c|}
\hline \multirow[b]{2}{*}{ Financial barrier } & \multicolumn{2}{|l|}{$\mathbf{M}$} & \multicolumn{2}{|c|}{ SD } & \multicolumn{2}{|l|}{$\mathbf{N}$} & \multirow[b]{2}{*}{$\mathbf{t}$} \\
\hline & Nonnural & Rural & Nonrural & Rural & Nonrural & Rural & \\
\hline Lack money for education & 2.13 & 2.16 & 0.68 & 0.65 & 518 & 328 & 0.53 \\
\hline
\end{tabular}

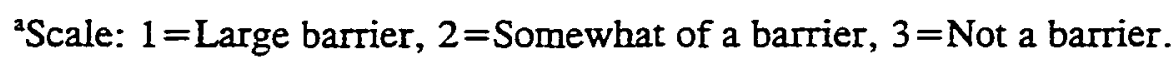

\section{Personal barriers}

The students were asked questions that revealed personal attitudes and perceptions that could be barriers to their educational and occupational aspirations. Table 100 reports the responses by private and public school students, and Table 101 shows the responses of nonrural and rural students. The range of means in Table 100 was $2.58-2.79$ on a scale of $1-3$ where $1=$ Large barrier and $3=$ Not a barrier. The range for nonrural and rural students was $2.54-2.86$. The students reported the barriers of personal attitudes and perceptions as negligible barriers to their educational and occupational aspirations. There were no statistically significant differences between the groups. 
Table 100. Personal attitudes and perceptions that could be barriers to educational and occupational aspirations for private and public school students ${ }^{2}$

Potential educational and occupational barriers

$\frac{\mathrm{M}}{\text { Private Public }} \frac{\mathrm{SD}}{\text { Private Public }} \frac{\mathrm{N}}{\text { Private Public }}$

Didn't take the right courses

Don't think I will be successful

2.66

Didn't get high enough grades

Don't have the necessary skills

2.58

2.69

2.65

0.56

0.56

198

653

0.21

2.59

2.60

0.60

0.59

$197 \quad 653$

1.52

Don't know about career

opportunities

2.73

2.73

0.59

0.57

$197 \quad 652$

0.09

Not wanting to work hard

2.58

2.58

0.49

0.51

198

652

0.06

I am not good at school work

2.86

2.86

0.59

0.61

$197 \quad 653$

0.10

2.59

2.52

0.40

0.42

198

652

0.08

0.62

0.62

$198 \quad 653$

0.71

aScale: $1=$ Large barrier, 2 =Somewhat of a barrier, $3=$ Not a barrier.

Table 101. Personal attitudes and perceptions that could be barriers to educational and occupational aspirations for nonrural and rural students ${ }^{2}$

\begin{tabular}{|c|c|c|c|c|c|c|c|}
\hline \multirow{2}{*}{$\begin{array}{l}\text { Potential educational } \\
\text { and occupational barriers }\end{array}$} & \multirow{2}{*}{\multicolumn{2}{|c|}{$\frac{\mathrm{M}}{\text { Nonrural Rural }}$}} & \multicolumn{2}{|c|}{ SD } & \multicolumn{2}{|l|}{$\mathrm{N}$} & \multirow[b]{2}{*}{$t$} \\
\hline & & & Nonrural & Rural & Nonrural & Rural & \\
\hline Didn't take the right courses & 2.68 & 2.70 & 0.56 & 0.57 & 520 & 328 & 0.59 \\
\hline Don't think I will be successful & 2.64 & 2.63 & 0.60 & 0.59 & 519 & 328 & -0.18 \\
\hline Didn't get high enough grades & 2.57 & 2.63 & 0.58 & 0.56 & 518 & 328 & 0.09 \\
\hline $\begin{array}{l}\text { Don't have the necessary skills } \\
\text { Don't know about career }\end{array}$ & 2.73 & 2.72 & 0.50 & 0.52 & 520 & 327 & 0.06 \\
\hline opportunities & 2.61 & 2.54 & 0.61 & 0.60 & 520 & 327 & 0.10 \\
\hline Not wanting to work hard & 2.85 & 2.86 & 0.43 & 0.39 & 520 & 327 & 0.08 \\
\hline I am not good at school work & 2.60 & 2.64 & 0.63 & 0.61 & 520 & 328 & 0.71 \\
\hline
\end{tabular}

${ }^{2}$ Scale: 1 =Large barrier, 2 =Somewhat of a barrier, $3=$ Not a barrier. 


\section{External barriers}

Tables 102 and 103 show variables that reported external factors that could serve as barriers to the students' educational and occupational aspirations for private and public school students and for nonrural and rural students. The means for the private and public school students ranged from 2.70-2.91 and the means for nonrural and rural students ranged from $2.66-2.88$ on a scale of $1-3$ where $1=$ Large barrier and $3=$ Not a barrier. The barriers shown in both tables were not perceived by the sudents as significant external barriers to their future aspirations. There were significant differences between the private and public school students on the variable "Lack of transportation." The public school students reported "Lack of transportation" as more of a barrier than private school students. The nonrural students reported that "Sexual discrimination" was as more of a barrier than rural students.

Table 102. External barriers to educational and occupational aspirations for private and public school students ${ }^{2}$

\begin{tabular}{|c|c|c|c|c|c|c|c|}
\hline \multirow[b]{2}{*}{ External barriers } & \multicolumn{2}{|c|}{$\mathbf{M}$} & \multicolumn{2}{|c|}{ SD } & \multicolumn{2}{|c|}{$\mathbf{N}$} & \multirow[b]{2}{*}{ t } \\
\hline & Private & Public & Private & Public & Private & Public & \\
\hline Lack of transportation & $2.87^{*}$ & $2.80 *$ & 0.42 & 0.51 & 197 & 652 & 1.95 \\
\hline Job I want doesn't pay enough & 2.70 & 2.66 & 0.51 & 0.59 & 198 & 653 & -1.05 \\
\hline Sexual discrimination & 2.89 & 2.86 & 0.40 & 0.44 & 198 & 653 & -0.97 \\
\hline Problem of racism & 2.91 & 2.87 & 0.36 & 0.45 & 198 & 653 & -1.38 \\
\hline \multicolumn{8}{|l|}{ Can't get into school of my } \\
\hline choice & 2.77 & 2.76 & 0.52 & 0.53 & 198 & 653 & -0.15 \\
\hline Parents disapprove of my goals & s 2.85 & 2.84 & 0.41 & 0.46 & 198 & 653 & -0.44 \\
\hline Family or home responsibilities & s 2.79 & 2.79 & 0.46 & 0.50 & 198 & 653 & 0.06 \\
\hline
\end{tabular}

${ }^{2}$ Scale: $1=$ Large barrier, 2 =Somewhat of a barrier, $3=$ Not a barrier.

${ }^{*} \underline{p}<.05$. 
Table 103. External barriers to educational and occupational aspirations for nonrural and rural students ${ }^{2}$

External barriers

$\frac{M}{\text { Nonrural Rural }} \frac{\mathrm{SD}}{\text { Nonrural Rural }} \frac{\mathrm{N}}{\text { Nonrural Rural }}$

Lack of transportation

Job I want doesn't pay enough

Sexual discrimination

2.83

2.81

0.49

0.50

520

$326-0.44$

Problem of racism

$2.89^{*}$

2.68

0.59

0.55

520

$328 \quad 0.67$

Can't get into school of my

2.88

$2.82 *$

0.39

0.44

520

$328-2.05$ choice

2.76

2.88

0.43

0.42

520

$328-0.53$

Parents disapprove of my goals

Family or home responsibilities

2.86

2.77

0.54

0.50

520

$328 \quad 0.45$

2.81

2.82

0.45

0.45

520

$328-1.23$

\subsection{5}

0.49

0.50

$\begin{array}{lll}520 & 328 & -1.82\end{array}$

${ }^{2}$ Scale: $1=$ Strongly agree, $2=$ Agree, 3 =Don't know, $4=$ Disagree, $5=$ Strongly disagree. ${ }^{*} \underline{p}<.05$.

\section{Educational barriers}

The students were asked questions that revealed their personal attitudes and perceptions about their school and their education. Tables 104 and 105 show the results for private and public school students and for nonrural and rural students. There were significant differences between the private and public school students on the three variables of "Students show respect for teachers," "I feel safe in school," and "My courses help me understand my everyday life." The private school students showed more agreement for the statements than did the students from the public schools.

Table 105 shows the means for nonrural and rural students. There were no statistically significant differences reported.

The students were asked to report an overall perception of their education in a different section of the questionnaire than where the questions to Tables 104 and 105 were located. 
Table 104. Personal attitudes and perceptions of private and public school students towards their school and their education ${ }^{2}$

Attitudes and

perceptions of education

$\frac{\mathrm{M}}{\text { Private } \quad \text { Public }} \frac{\mathrm{SD}}{\text { Private Public }} \frac{\mathrm{N}}{\text { Private Public } t}$

I have a teacher who is a positive role model for me

Students show respect for teachers

I feel safe in school

1.99

2.03

1.00

0.99

197

651

0.44

I am usually bored in school

$2.55^{* *}$

$2.83^{* *}$

0.85

1.01

195

$650 \quad 4.02$

$1.84^{*}$

$1.99 *$

0.84

0.87

197

$\begin{array}{ll}651 & 2.17\end{array}$

My courses help me understand my everyday life

2.49*

$2.69 *$

0.85

1.05

196

$651 \quad-1.47$

What I learn in school will benefit my future

1.66

1.76

0.78

0.97

195

650

2.88

Teachers respect my thoughts

2.78

2.28

0.98

0.83

198

$\begin{array}{ll}652 & 1.47\end{array}$

197

$649-1.10$

aScale: 1 =Strongly agree, 2 =Agree, 3 =Don't know, 4 =Disagree, $5=$ Strongly disagree.

$* \mathrm{p}<.05$.

$* * \mathrm{~g}<.01$.

Table 105. Personal attitudes and perceptions of nonrural and rural students towards their school and their education ${ }^{2}$

Attitudes and

perceptions of education

$\frac{M}{\text { Nonrural Rural }} \frac{\text { SD }}{\text { Nonrural Rural }}$

$\frac{\mathrm{N}}{\text { Nonrural Rural }} \mathrm{t}$

I have a teacher who is a positive role model for me

Students show respect for teachers

I feel safe in school

2.00

2.06

1.00

1.00

517

328

0.85

I am usually bored in school

\subsection{1}

2.70

1.01

0.95

515

$327-1.59$

1.97

1.93

0.87

0.84

517

$328-0.66$

2.44

2.46

1.04

1.09

516

328

0.25

My courses help me understand my everyday life

2.61

2.67

0.96

0.93

515

$327-1.02$

What I learn in school will benefit my future

1.73

1.74

0.83

0.79

0.97

1.02

519

515

$\begin{array}{ll}328 & 0.31\end{array}$

2.43

$328 \quad 0.66$

aScale: 1 =Strongly agree, $2=$ Agree, 3 =Don't know, $4=$ Disagree, $5=$ Strongly disagree. 
Figure 3 displays the results of the students' perception of the quality of their education for all of AEA 4. Slightly over two-thirds of the students responded by indicating that their education was "good" or "excellent."

The results of the private and public school students and the nonrural and rural students are shown in Tables 106 and 107. The data presented in the tables excluded the answer "Don't know" and were then treated as interval data for analysis. There were significant differences between the private school students and the public school students and for the nonrural and rural students. Private school students and rural students felt that their education was of a higher quality than the public school students and the nonrural students.

Table 108 shows the perception of students who had taken agriculture courses about the quality of their education of students was compared to students who had not taken agriculture courses. The students who had not taken agriculture courses had a significantly more positive perception of their education than students who had taken agriculture courses.

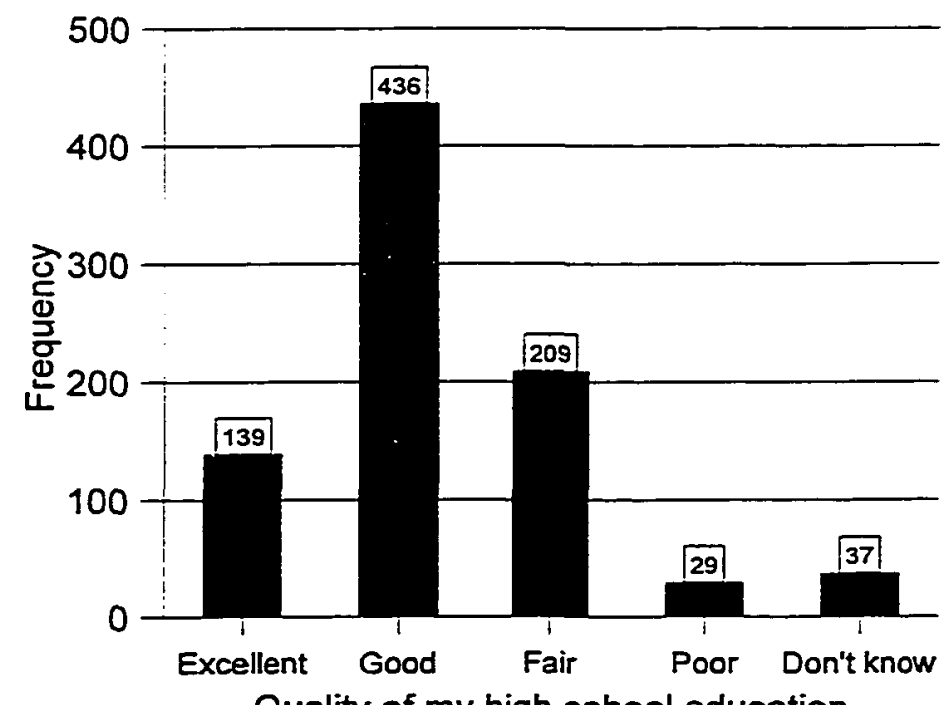

Figure 3. Perception of school quality by high school seniors $(\mathrm{N}=850)$ 
Table 106. Personal attitudes and perceptions of private and public students towards the quality of their education ${ }^{2}$

Factor

$\frac{\mathrm{M}}{\text { Private** }^{* *} \text { Public** }} \frac{\mathrm{SD}}{\text { Private Public }} \frac{\mathrm{N}}{\text { Private Public } t}$

Quality of education

$1.91 \quad 2.23$

0.79

0.71

189

$624 \quad 5.22$

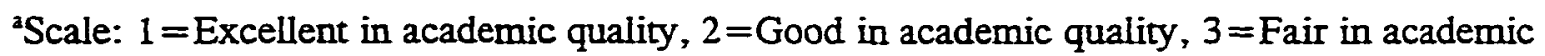
quality, $4=$ Poor in academic quality.

$* * \mathrm{p}<.01$.

Table 107. Personal attitudes and perceptions of nonrural and rural students towards the quality of their education ${ }^{2}$

\begin{tabular}{|c|c|c|c|c|c|c|c|}
\hline \multirow[b]{2}{*}{ Factor } & \multicolumn{2}{|c|}{$\mathbf{M}$} & \multicolumn{2}{|c|}{ SD } & \multicolumn{2}{|c|}{$\mathrm{N}$} & \multirow[b]{2}{*}{$\mathrm{t}$} \\
\hline & Nonrural* & Rural* & Nonrural & Rural & Nonrural & Rural & \\
\hline Quality of education & 2.20 & 2.08 & 0.73 & 0.75 & 500 & 310 & 2.18 \\
\hline
\end{tabular}

${ }^{2}$ Scale: $1=$ Excellent in academic quality, $2=$ Good in academic quality, $3=$ Fair in academic quality, $4=$ Poor in academic quality.

${ }^{*} \mathrm{p}<.05$.

Table 108. Personal attitudes and perceptions of students who have and have not taken agriculture courses towards the quality of their education ${ }^{2}$

\begin{tabular}{|c|c|c|c|c|c|c|c|}
\hline \multirow[b]{2}{*}{ Factor } & \multicolumn{2}{|c|}{$\mathbf{M}$} & \multicolumn{2}{|c|}{ SD } & \multicolumn{2}{|c|}{$\mathbf{N}$} & \multirow[b]{2}{*}{$\mathrm{t}$} \\
\hline & Taken ag** & No ag** & Taken ag & No ag & Taken ag & No ag & \\
\hline Quality of education & 2.28 & 2.11 & 0.74 & 0.73 & 231 & 580 & 3.07 \\
\hline
\end{tabular}

aScale: $1=$ Excellent in academic quality, $2=$ Good in academic quality, $3=$ Fair in academic quality, $4=$ Poor in academic quality.

$* * \mathrm{p}<.01$. 


\section{3}

Table 109 shows the "Occupation desired" and the "Occupation I will probably have" for private and public school students. The "Occupation desired" showed no statistically significant

differences between private and public school students in their aspirations for a future occupation. The desired occupation with the greatest percentage of students was "Healthcare Practitioners and Technical Occupations" for private school students (15.4\%), and public school students had a top ranking with "Management Occupations" (13.9\%). The second-ranked occupational selection for private school students was "Management Occupations" (13.9\%). "Education, Training, and Library Occupations" ranked third (private $=7.4 \%$; public $=11.2 \%$ ), and "Arts, Design, Entertainment, and Sports Occupations" ranked fourth (private $=7.4 \%$; public $=9.2 \%$ ).

The students reported the occupation they thought they would probably have by age 30 . "Healthcare Practitioners and Technical Occupations" remained the top-ranked selection for private school students (15.8\%). "Management Occupations" became the first selection for public school students of a probable occupation (13.7\%), and "Education, Training, and Library Occupations" became the second-ranked selection (13.3\%) for public school students. Private school students ranked "Management Occupations" second (9.3\%). "Education, Training, and Library Occupations" (6.0\%) and "Arts, Design, Entertainment, and Sports Occupations" (6.0\%) had the same ranking, sharing fourth and fifth rankings. The public school students ranked "Arts, Design, Entertainment, and Sports Occupations" fourth (6.3\%) and "Business and Financial Operations Occupations" fifth (4.8\%).

Table 110 shows the "Occupation desired" and the "Occupation I will probably have" for nonrural and rural students. For "Occupation desired," the greatest percentage of students indicated an intention to pursue "Healthcare Practitioners and Technical Occupations" (14.0\%) followed by "Education, Training, and Library Occupations" (12.1\%) followed by "Management Occupations" (11.1\%). For the "Occupation I will probably have," the greatest percentage of 
Table 109. Occupation desired and occupation that students indicated they would probably have by age 30 for private and public school students

\begin{tabular}{|c|c|c|c|c|c|c|c|c|c|c|}
\hline & \multicolumn{5}{|c|}{ Occupation desired } & \multicolumn{5}{|c|}{ Occupation probably have } \\
\hline & \multicolumn{2}{|c|}{ Private } & \multicolumn{2}{|c|}{ Public } & \multirow[b]{2}{*}{$\mathbf{N}$} & \multicolumn{2}{|c|}{ Private** } & \multicolumn{2}{|c|}{ Public** } & \multirow[b]{2}{*}{$\mathbf{N}$} \\
\hline & $\underline{\mathbf{f}}$ & $\%$ & $\underline{\mathrm{f}}$ & $\%$ & & $\underline{f}$ & $\%$ & $\underline{f}$ & $\%$ & \\
\hline Management & 26 & 13.8 & 83 & 13.9 & 109 & 17 & 9.3 & 80 & 13.7 & 97 \\
\hline Business and Financial Operations & 6 & 3.2 & 29 & 4.8 & 35 & 6 & 3.3 & 28 & 4.8 & 34 \\
\hline Computer and Mathematical & 9 & 4.8 & 18 & 3.0 & 27 & 11 & 6.0 & 17 & 2.9 & 28 \\
\hline Architecture and Engineering & 7 & 3.7 & 22 & 3.7 & 29 & 5 & 2.7 & 21 & 3.6 & 26 \\
\hline Life, Physical, and Social Science & 7 & 3.7 & 29 & 4.8 & 36 & 7 & 3.8 & 26 & 4.4 & 33 \\
\hline Community and Social Service & 8 & 4.3 & 15 & 2.5 & 23 & 6 & 3.3 & 17 & 2.9 & 23 \\
\hline Legal & 0 & 0.0 & 11 & 1.8 & 11 & 0 & 0.0 & 7 & 1.2 & 7 \\
\hline Education, Training, Library & 14 & 7.4 & 67 & 11.2 & 81 & 16 & 8.7 & 78 & 13.3 & 94 \\
\hline $\begin{array}{l}\text { Arts, Design, Entertainment, } \\
\text { and Sports }\end{array}$ & 14 & 7.4 & 55 & 9.2 & 69 & 11 & 6.0 & 37 & 6.3 & 48 \\
\hline Healthcare Practitioners and & & & & & & & & & & \\
\hline Technical & 29 & 15.4 & 83 & 13.9 & 112 & 29 & 15.8 & 70 & 11.9 & 99 \\
\hline Healthcare Support & 3 & 1.6 & 12 & 2.0 & 15 & 3 & 1.6 & 13 & 2.2 & 16 \\
\hline Protective Services & 7 & 3.7 & 16 & 2.7 & 23 & 8 & 4.4 & 14 & 2.4 & 22 \\
\hline Food Preparation and Serving & & & & & & & & & & \\
\hline Related & 4 & 2.1 & 4 & 0.7 & 8 & 1 & 0.5 & 13 & 2.2 & 14 \\
\hline Building, Grounds, Cleaning, & & & & & & & & & & \\
\hline Maintenance & 0 & 0.0 & 4 & 0.7 & 4 & 0 & 0.0 & 5 & 0.9 & 5 \\
\hline Personal Care and Services & 5 & 2.7 & 24 & 4.0 & 29 & 6 & 3.3 & 18 & 3.1 & 24 \\
\hline Sales and Related & 1 & 0.5 & 15 & 2.5 & 16 & 2 & 1.1 & 14 & 2.4 & 16 \\
\hline Office and Administrative Support & 4 & 2.1 & 5 & 0.8 & 9 & 9 & 4.9 & 9 & 1.5 & 18 \\
\hline Farming, Fishing, Forestry & 1 & 0.5 & 3 & 0.5 & 4 & 1 & 0.5 & 3 & 0.5 & 4 \\
\hline Construction and Extraction & 5 & 2.7 & 10 & 1.7 & 15 & 10 & 5.5 & 17 & 2.9 & 27 \\
\hline Installation, Maintenance, Repair & 9 & 4.8 & 15 & 2.5 & 24 & 6 & 3.3 & 13 & 2.2 & 19 \\
\hline Production & 1 & 0.5 & 5 & 0.8 & 6 & 3 & 1.6 & 11 & 1.9 & 14 \\
\hline Transportation and Material Moving & 1 & 0.5 & 9 & 1.5 & 10 & 1 & 0.5 & 7 & 1.2 & 8 \\
\hline Military & 1 & 0.5 & 6 & 1.0 & 7 & 0 & 0.0 & 7 & 1.2 & 7 \\
\hline Make Money/Good job & 11 & 5.9 & 2.7 & 4.5 & 38 & 5 & 2.7 & 15 & 2.6 & 20 \\
\hline Uncertain $^{2}$ & 3 & 1.6 & 13 & 2.2 & 16 & 3 & 1.6 & 26 & 4.4 & 29 \\
\hline Housewife ${ }^{2}$ & 10 & 5.3 & 11 & 1.8 & 21 & 12 & 6.6 & 9 & 1.5 & 21 \\
\hline Strange, inappropriate ${ }^{2}$ & 2 & 1.1 & 8 & 1.4 & 10 & 5 & 2.7 & 8 & 1.5 & 14 \\
\hline Father/Dad & 0 & 0.0 & 0 & 0.0 & 0 & 0 & 0.0 & 1 & 0.2 & 1 \\
\hline Totals & 188 & & 599 & & 787 & 183 & & 585 & & 768 \\
\hline
\end{tabular}
Statistics.

${ }^{2}$ Not a category listed in the Standard Occupational Classification of the Bureau of Labor

$$
* * \chi^{2}(28, \mathrm{~N}=769)=54.53, \mathrm{p}<.01 \text {. }
$$


Table 110. Occupation desired and occupation that students indicated they would probably have by age 30 for nonrural and rural students

\begin{tabular}{|c|c|c|c|c|c|c|c|c|c|c|}
\hline & \multicolumn{5}{|c|}{ Occupation desired } & \multicolumn{5}{|c|}{ Occupation probably have } \\
\hline & \multicolumn{2}{|c|}{ Nonrural } & \multicolumn{2}{|c|}{ Rural } & \multirow[b]{2}{*}{$\mathbf{N}$} & \multicolumn{2}{|c|}{ Nonnural* } & \multicolumn{2}{|c|}{ Rural* } & \multirow[b]{2}{*}{$\mathrm{N}$} \\
\hline & $\underline{f}$ & $\%$ & $\underline{f}$ & $\%$ & & $\underline{\mathbf{f}}$ & $\%$ & $\underline{f}$ & $\%$ & \\
\hline Management & 53 & 11.1 & 56 & 18.3 & 109 & 48 & 10.3 & 49 & 16.3 & 97 \\
\hline Business and Financial Operations & 26 & 5.4 & 9 & 2.9 & 35 & 26 & 5.6 & 8 & 2.7 & 34 \\
\hline Computer and Mathematical & 16 & 3.3 & 11 & 3.6 & 27 & 16 & 3.4 & 12 & 4.0 & 28 \\
\hline Architecture and Engineering & 17 & 3.6 & 11 & 3.6 & 28 & 16 & 3.4 & 10 & 3.3 & 26 \\
\hline Life, Physical, and Social Science & 25 & 5.2 & 11 & 3.6 & 36 & 21 & 4.5 & 12 & 4.0 & 33 \\
\hline Community and Social Service & 14 & 2.9 & 9 & 2.9 & 23 & 12 & 2.6 & 11 & 3.7 & 23 \\
\hline Legal & 10 & 2.1 & 1 & 0.3 & 11 & 6 & 1.3 & 1 & 0.3 & 7 \\
\hline Education, Training, Library & 58 & 12.1 & 23 & 7.5 & 81 & 69 & 14.8 & 25 & 8.3 & 94 \\
\hline $\begin{array}{l}\text { Arts, Design, Entertainment, } \\
\text { and Sports }\end{array}$ & 38 & 7.9 & 31 & 10.1 & 69 & 27 & 5.8 & 21 & 7.0 & 48 \\
\hline $\begin{array}{l}\text { Healthcare Practitioner } \\
\text { Technical }\end{array}$ & 67 & 14.0 & 45 & 14.7 & 112 & 59 & 12.6 & 40 & 13.3 & 99 \\
\hline Healthcare Support & 6 & 1.3 & 9 & 2.9 & 15 & 7 & 1.5 & 9 & 3.0 & 16 \\
\hline $\begin{array}{l}\text { Protective Services } \\
\text { Food Preparation and Serving }\end{array}$ & 12 & 2.5 & 11 & 3.6 & 23 & 13 & 2.8 & 9 & 3.0 & 22 \\
\hline Related & 4 & 0.8 & 4 & 1.3 & 8 & 12 & 2.6 & 2 & 0.7 & 14 \\
\hline Building, Grounds, Cleaning, & & & & & & & & & & \\
\hline Maintenance & 2 & 0.4 & 2 & 0.7 & 4 & 2 & 0.4 & 3 & 1.0 & 5 \\
\hline Personal Care and Services & 20 & 4.2 & 9 & 2.9 & 29 & 8 & 2.7 & 8 & 2.7 & 24 \\
\hline Sales and Related & 12 & 2.5 & 3 & 1.0 & 15 & 11 & 2.4 & 4 & 1.3 & 15 \\
\hline Office and Administrative Support & 4 & 0.8 & 5 & 1.6 & 9 & 10 & 2.1 & 8 & 2.7 & 18 \\
\hline Farming, Fishing, Forestry & 3 & 0.6 & 1 & 0.3 & 4 & 3 & 0.6 & 1 & 0.3 & 4 \\
\hline Construction and Extraction & 8 & 1.7 & 7 & 2.3 & 15 & 10 & 2.1 & 17 & 5.7 & 27 \\
\hline Installation, Maintenance, Repair & 17 & 3.6 & 7 & 2.3 & 24 & 13 & 2.8 & 6 & 2.0 & 19 \\
\hline Production & 2 & 0.4 & 3 & 1.0 & 5 & 7 & 1.5 & 6 & 2.0 & 13 \\
\hline Transportation and Material Moving & 9 & 1.9 & 1 & 0.3 & 10 & 5 & 1.1 & 3 & 1.0 & 8 \\
\hline Military & 2 & 0.4 & 5 & 1.6 & 7 & 1 & 0.2 & 6 & 2.0 & 7 \\
\hline Make Money/Good job & 24 & 5.0 & 14 & 4.6 & 38 & 12 & 2.6 & 8 & 2.7 & 20 \\
\hline Uncertain $^{2}$ & 11 & 2.3 & 5 & 1.6 & 16 & 21 & 4.5 & 8 & 2.7 & 29 \\
\hline Housewife $^{2}$ & 12 & 2.5 & 9 & 2.9 & 21 & 12 & 2.6 & 9 & 3.0 & 21 \\
\hline Strange, inappropriate & 6 & 1.3 & 4 & 1.3 & 10 & 11 & 2.4 & 4 & 1.3 & 15 \\
\hline Father/Dad & 0 & 0.0 & 0 & 0.0 & 0 & 1 & 0.2 & 0 & 0.0 & 1 \\
\hline Totals & 478 & & 306 & & 784 & 467 & & 300 & & 767 \\
\hline
\end{tabular}
Statistics.

${ }^{2}$ Not a category listed in the Standard Occupational Classification of the Bureau of Labor

$$
{ }^{*} \chi^{2}(28, \mathrm{~N}=767)=43.9, \mathrm{p}<.05 \text {. }
$$


students selected "Education, Training, and Library Occupations" (14.8\%) followed by

"Healthcare Practitioners and Technical Occupations" (12.6\%) and "Management Occupations" $(10.3 \%)$

There was a statistically significant difference between the nonrural and rural groups for the "Occupation I will probably have." The "Healthcare Practitioner and Technical Occupations" differed between the nonrural (14.8\%) and rural (8.3\%), "Management Occupations" differed (nonrural $=10.3 \%$; rural $=16.3 \%$ ), and "Education, Training, and Library Occupations" (nonrural $=14.8 \%$; rural $=8.3 \%$ ) more than $5 \%$.

Tables 111 and 112 show the frequency of the students' response to the question, "Where do you think you will be living at age 30 ? (Select best answer)" for private and public school students and nonrural and rural students. A chi-square analysis indicated significant differences between the private and public school students and between the nonrural and rural students.

The greatest percentage of students answered "I have no idea" (private $=42.9 \%$;

public $=43 \%$ ). The next most frequent answer for the private school students was "In the local

Table 111. Frequency of where students indicated they will live by age 30 for private and public school students

\begin{tabular}{|c|c|c|c|c|c|c|c|c|c|c|c|}
\hline & \multirow[b]{2}{*}{$N$} & \multicolumn{2}{|c|}{$\begin{array}{c}\text { Local } \\
\text { area }\end{array}$} & \multicolumn{2}{|c|}{$\begin{array}{c}\text { Within } \\
75 \text { miles }\end{array}$} & \multicolumn{2}{|c|}{$\begin{array}{c}75-200 \\
\text { miles }\end{array}$} & \multicolumn{2}{|c|}{$\begin{array}{c}>200 \\
\text { miles }\end{array}$} & \multicolumn{2}{|c|}{ No idea } \\
\hline & & $\underline{\mathrm{f}}$ & $\%$ & $\overline{\mathrm{f}}$ & $\%$ & $\underline{f}$ & $\%$ & $\underline{\mathrm{f}}$ & $\%$ & $\underline{\mathrm{f}}$ & $\%$ \\
\hline Private** & 196 & 37 & 18.9 & 33 & 16.8 & 20 & 10.2 & 22 & 11.2 & 84 & 42.9 \\
\hline Public** & 654 & 62 & 9.5 & 79 & 12.1 & 95 & 14.5 & 137 & 20.9 & 281 & 43.0 \\
\hline
\end{tabular}

$* * \chi^{2}(4, \mathrm{~N}=850)=23.73, \mathrm{p}<.01$ 
area where I now live" (18.9\%), but for the public school students, the next most frequent response was the answer, "More than 200 miles away" (20.9\%).

The most frequent answer for the nonrural and rural students in Table 112 was "I have no idea" (nonrural=43.5\%; rural $=42.1 \%$ ). The next most frequent answer for the rural students was "In the local area where I now live" (17.4\%) compared to $7.9 \%$ for the nonrural students. The nonrural students' second most frequent answer was "More than 200 miles away" (21.4\%).

Table 112. Frequency of where students indicated they will live by age 30 for nonrural and rural students

\begin{tabular}{|c|c|c|c|c|c|}
\hline & $\begin{array}{c}\text { Local } \\
\text { area }\end{array}$ & $\begin{array}{c}\text { Within } \\
75 \text { miles }\end{array}$ & $\begin{array}{c}75-200 \\
\text { miles } \\
\end{array}$ & $\begin{array}{c}>200 \\
\text { miles }\end{array}$ & No idea \\
\hline & $\underline{\mathbf{f}}$ & $\%$ & $\underline{f}$ & $\%$ & $\%$ \\
\hline
\end{tabular}

\begin{tabular}{lrrrrrrrrrrr} 
Nonrural** & 579 & 41 & 7.9 & 69 & 13.3 & 72 & 13.9 & 111 & 21.4 & 226 & 43.5 \\
Rural** & 328 & 57 & 17.4 & 43 & 13.1 & 43 & 13.1 & 47 & 14.3 & 138 & 42.1 \\
\hline
\end{tabular}

$$
* * \chi^{2}(4, \mathrm{~N}=847)=21.17, \mathrm{p}<.01 \text {. }
$$

\section{Correlations}

Correlation coefficients were computed using the statistical test that was appropriate for the data analyzed. Correlations measured how the variables are related. The degree of relationship was described by the scale presented by Davis (1971):

$\begin{array}{ll}\text { Coefficient } & \text { Description } \\ .70 \text { or higher } & \text { Very strong relationship } \\ .50-.69 & \text { Substantial relationship } \\ .30-.49 & \text { Moderate relationship } \\ .10-.29 & \text { Low relationship } \\ .01-.09 & \text { Negligible relationship }\end{array}$


Pearson correlations were used for interval scales. When the two measures were nominal scales, Cramer's V was computed. Interval by nominal data were measured using the Eta statistic available on SPSS ${ }^{\circ}$

Correlations were computed for private and public school students and for nonrural and rural students. Correlations were computed on questions 35-52 of the questionnaire, which was the section "...barriers that may keep you from ACHIEVING YOUR FUTURE GOALS." The variables produced correlations ranging from 0.02 to 0.09 . Based on the Davis descriptors, all of the correlations were of a negligible relationship.

Correlations were computed for questions $53-59$, which were the "factors that could IMPROVE YOUR OPPORTUNITIES. " The correlations ranged from $0.03-0.15$ for private and public school students and nonrural and rural students.

Correlations were computed for questions $60-83$, which were in the section, "How important are the following TO YOUR FUTURE?". Table 113 shows the variables computed and if they had a correlation of 0.20 or greater. The variables marital status, gender, and financial condition had values of less than 0.20 .

Correlations were computed for questions 84-100, which were the "Factors of the Agreement" about their school, parents, and themselves. Table 114 shows the variables computed and if the variables had a correlation of 0.20 or greater. 
Table 113. Relationships of selected variables and the qualities that were important to the student's future ${ }^{a}$

$\begin{array}{lcccc}\begin{array}{l}\text { Publicl } \\ \text { private }\end{array} & \begin{array}{c}\text { Nonrural/ } \\ \text { rural }\end{array} & \text { GPA } & \begin{array}{c}\text { Church } \\ \text { activity }\end{array} & \begin{array}{c}\text { Plans to } \\ \text { attend school }\end{array}\end{array}$

Live near a church

of my faith

.32

.13

.16

.43

.14

Find right person to marry

.07

.10

.17

.21

.21

Get a 2-year degree

.05

.07

.23

.10

.19

Get a 4-year degree

.14

.13

.24

.14

.43

Live out in the country on a farm or acreage

.04

.31

.07

.09

.17

Having a spiritually

fulfilling life

.22

.08

.21

.40

.19

Provide volunteer service in my community

.07

.06

.14

.23

.10

Trying to do the right thing

.03

.06

.20

.12

.20

Raising a family

.06

.03

.14

.21

.22

${ }^{2}$ The data were analyzed as nominal by interval data and the Eta correlation option was used in SPSS ${ }^{\circledR}$. 
Table 114. Relationships of selected variables and the perceptions of school, parents, and selves ${ }^{2}$

\begin{tabular}{|c|c|c|c|c|c|c|c|}
\hline & $\begin{array}{l}\text { Private/ } \\
\text { public }\end{array}$ & $\begin{array}{l}\text { Nonrural/ } \\
\text { rural }\end{array}$ & GPA & $\begin{array}{l}\text { Marital } \\
\text { status }\end{array}$ & $\begin{array}{l}\text { Plans to } \\
\text { attend } \\
\text { school }\end{array}$ & $\begin{array}{l}\text { Financial } \\
\text { status }\end{array}$ & $\begin{array}{l}\text { Church } \\
\text { activity }\end{array}$ \\
\hline I am optimistic & .02 & .02 & .17 & .13 & .30 & .11 & .09 \\
\hline $\begin{array}{l}\text { Parents are positive } \\
\text { role models }\end{array}$ & .08 & .09 & .20 & .23 & .22 & .21 & .28 \\
\hline $\begin{array}{l}\text { Teachers respect my } \\
\text { thoughts }\end{array}$ & .04 & .02 & .20 & .07 & .19 & .11 & .14 \\
\hline $\begin{array}{l}\text { Parents think college } \\
\text { important }\end{array}$ & .06 & .08 & .24 & .15 & .45 & .12 & .16 \\
\hline $\begin{array}{l}\text { What I learn in school } \\
\text { will benefit my future }\end{array}$ & .05 & .01 & .23 & .13 & .21 & .06 & .07 \\
\hline $\begin{array}{l}\text { I put forth necessary effort } \\
\text { to reach goal }\end{array}$ & .02 & .03 & .21 & .09 & .18 & .10 & .11 \\
\hline I feel safe in school & .07 & .02 & .21 & .10 & .21 & .10 & .17 \\
\hline My parents like my school & .19 & .07 & .20 & .17 & .16 & .15 & .26 \\
\hline I am a positive role model & .07 & .02 & .28 & .07 & .22 & .07 & .18 \\
\hline
\end{tabular}

${ }^{2}$ The data were analyzed as nominal by interval data and the Eta correlation option was used in SPSS ${ }^{\circledR}$. 


\section{CHAPTER V. SUMMARY}

\section{Objectives}

The objectives of the study were to:

1. Describe the personal and educational characteristics of rural high school seniors in AEA 4 in northwest Iowa.

2. Describe the educational, occupational, and personal aspirations to a fulfilling adulthood of rural high school seniors in AEA 4.

3. Identify barriers and disadvantages that may affect educational and occupational aspirations of rural high school seniors.

4. Identify educational aspirations of rural students who reside in town and the country.

5. Describe the characteristics of students who took agriculture courses, were involved in FFA, or participated in 4-H.

6. Describe the characteristics of students of private and public schools who were located in a rural area.

7. Describe the strength of relationship between selected factors of the students.

The data for the objectives were analyzed using descriptive statistics. Frequencies, percentages, means, standard deviations, and correlations were used to analyze the data. Relationships were described using the appropriate correlation coefficients; Cramer's V statistic or Eta in SPSS ${ }^{\oplus}$. Some of the data were treated as interval data. With populations of normal distribution, "it is common in practice to assign scores to levels and treat it as a quantitative variable" (Agresti \& Finlay, p. 440). The data were treated as interval data from one to three for the possible answers of "Large barrier (1)," "Somewhat of a barrier (2)," or "Not a barrier (3)" or for the data that provided the possible answers of "Very important (1)," "Somewhat important 
(2)," and "Not important (3)". The data were treated as interval data from one to five when there were five possible answers of "Strongly agree (1)," "Agree (2)," "Don't know (3)," "Disagree (4)" and "Strongly disagree (5)."

\section{Population}

The population of this study of rural education in Iowa included the population of all of the high schools in education district AEA 4 which was located in northwest Iowa and included schools in Cherokee, Lyon, O'Brien, Osceola, and Sioux counties. There were thirteen public schools and four private schools.

The review of literature on rural education revealed the absence of a consistent and common definition of rural education. The definition of rural has been problematic because rural has been used to describe areas outside of towns and cities, and the diversity outside the city limits has been quite diverse. In some instances, poverty was commonly associated with rural and in other instances, rural described prosperous agricultural communities that were flourishing. The government's definitions of rural were placed in Appendix E.

For the purposes of this study, a rural school in Iowa met the following criteria: (1) located in a county of a total population of 40,000 people or less, 2 ) located in a county outside a Metropolitan Statistical Area, 3) had a high school enrollment of less than 500 students, 4) and were located in communities that were affected by production agriculture.

Table 2 showed that all of the schools in AEA 4 met the criteria. The county populations were: 1) Cherokee County, 13,191; Lyon County 12,012; Osceola County 6,960; O'Brien County 14,910; and Sioux County 31,280 (U.S. Census, 1998).

The school size in grades 9-12 ranged from largest school, Hull Western Christian, with 438 students to Spalding Catholic with 95 students. The average size of the studied senior classes 
for AEA 4 was 62 students. The average size of the senior class in private schools was 63 students, and the average size class of the public schools was 61 students.

The agricultural activity in AEA 4 was extensive in livestock and crop production. The public schools offered agriculture courses in their schools with full-time or shared instructors. Two of the schools, West Lyon and Sibley-Ocheydan, had two full-time instructors for their agriculture programs. The private schools did not have agriculture programs in their schools.

The census study allowed the researcher to examine for differences within a defined rural area. Differences were examined between students who lived in town in houses and apartments and students who lived in the country on acreages, small farms, and large farms.

The study allowed the examination of differences that existed between private and public schools due to the number of private schools that existed in AEA 4. One school was a parochial school of the Catholic church, and each of the other three schools was organized and independently run by a society of individuals who shared similar philosophical and religious beliefs. They were not governed or operated by churches.

The place where the students lived was reported in Table 7 for private and public school students and the totals were given for AEA 4. The students who lived in town in a house or apartment comprised $58.4 \%$ of the students, and the students living in the country on an acreage, small farm, or large farm comprised $41.4 \%$ of the students. Of the students living in the country, the greatest percentage lived on acreages $(17.2 \%)$ followed by students living on small farms (15.5\%) followed by students living on large farms (8.7\%). Similar categorical definitions were not found in the literature, but the breakdown revealed a substantial number of the students living in the country who may have differing roles of involvement in agriculture. 
The percentage of private school students who resided in the country was greater than for the public school students (56.1\% and $37.1 \%$ ), and the percentages for each rural category were greater for the private school students than the public school students.

The 1992 Census of Agriculture provided a description of the average farm size in each of the counties included in the study. The average farm size was 248 acres in Sioux County followed by Lyon (291 acres), O'Brien (316 acres), Cherokee (343 acres), and Osceola (354 acres) counties.

\section{Research Question 1}

The first research question stated that "There will be no difference in frequency distribution for college, university, trade, or business school aspirations of nonrural students and rural students." Table 77 showed that $90.8 \%$ of the seniors in AEA 4 planned to attend a college, university, trade, or business school. Ninety-one and two-tenths percent of the students who lived in town had intentions of "Likely attend" or "Definitely attend," and $89.3 \%$ of the rural students planned to attend a college, university, trade, or business school after graduation. There was no statistically significant difference between the nonrural and rural students for their college aspirations to attend a college, university, trade, or business school.

O'Dell's (1986) study in Ohio reported that $62 \%$ of the students reported that they would definitely attend or would likely attend college. The rural students of AEA 4 reported a substantially higher intention (90.8\%) to enroll in higher education. The O'Dell study did not include the "trade or business school" in their answer. The National Center for Educational Statistics (NCES) (1998) reported in the Education Digest that "enrollment in higher education increased by $14 \%$ from 1986 to $1996 "$ (p. 187), and for $1998,18.3 \%$ of the students did not have plans to attend college. The NCES reported that much of the enrollment increase was attributed to 
increased female enrollments. The increase reported by the NCES helped explain the much lower intentions reported by O'Dell in 1986.

The Northwest Iowa Aspiration Study showed a higher enrollment intent than was reported by the NCES. Table 82 showed that $94.5 \%$ of the females in AEA 4 would likely continue their education and $85.4 \%$ of the males had aspirations to continue their education. The percentages reported in AEA 4 showed more females than males planned to continue their education which follows the national trend.

There were no significant differences in the aspirations of the students to continue their education between rural and nonrural students in AEA 4.

\section{Research Question 2}

Research Question 2 stated that "There will be no difference in the frequency distribution for college aspirations of students who took agriculture courses and those who did not." Tables 83 and 84 showed that there was a significant difference in the aspirations of students who had and had not taken agriculture courses. Students who had taken agriculture courses were less committed to continuing their education for four years than students who had not taken agriculture courses. The results supported what has been reported in the literature that rural students have lower educational aspirations than their urban counterparts (Cobb et al., 1989, p. 11). All of the students examined in this study were rural students but were examined by where they lived, in town in a house or apartment, or in the country on an acreage, small farm, or large farm.

Similar results were reported for students who had FFA experience and those who did not. Those with FFA experience were less committed to continuing their education than the students who had not participated in FFA. The intentions between the two groups were significantly 
different and were reported in Table 42. Students involved in the agricultural curriculum and activities of the school had less intentions of continuing their education than those who were not involved.

Agriculture courses and FFA were not offered in the private schools, and the data were examined for only the public schools. The results were consistent. Students in the public schools who were involved in agriculture courses or FFA were less committed to continuing their education than the students not involved in the agriculture courses or FFA.

There were significant differences in the college aspirations of students who took agriculture courses and those who did not in AEA 4.

\section{Research Question 3}

Research Question 3 stated that "There will be no difference in the frequency distribution for personal qualities of rural students who lived in the country and those who lived in town." Table 69 showed the personal qualities, "I am dependable," "I put forth necessary effort to reach a goal," "I am optimistic," and "I make sacrifices today to benefit my future." The nonrural and rural students reported very similar perceptions, and there was no significant difference between the two groups. The students agreed most strongly that they were dependable followed by "I am optimistic," "I put forth the necessary effort to reach a goal," and "I make sacrifices today to benefit my future." The means indicated that the students reported between "Strongly agree" and "Agree" in their self-analysis of their personal qualities except for the mean for "I am willing to sacrifice for my future." The mean was 2.23 , which was a value between "Agree" and "Unsure." The students reported positively about their personal qualities. 
The literature reported that knowing what students feel about themselves provides insight into their aspirations. The students had positive feelings about themselves which would indicate that their aspirations would be positively influenced.

Ley, Nelson, and Beltyukova (1996) reported that students placed "I am dependable" as the top-ranked personal trait which was also the case in this study. In the Ley study of 21 rural high schools in 21 states, the students had a mean of 1.143. The students in the AEA 4 study had a mean of 1.71 .

There was no difference in the frequency distribution for personal qualities of rural students who live in the country and those who live in town.

\section{Research Question 4}

Research Question 4 stated that "There will be no difference in the frequency distribution for family concerns of rural students who live in the country and those who live in town." Table 71 showed the parental qualities of the students of nonrural and rural students. There were significant differences between the nonrural and rural students. Students who lived in the country reported more agreement than the students who lived in town for the two variables, "My parents are positive role models," and "My parents like my school." The students who lived in town showed significantly more agreement for the variable, "My parents think going to college is important for me."

Table 73 showed family concerns affecting a successful adulthood of nonrural and rural students. The students who lived in the country placed more importance on the variable, "Find the right person to marry," and was significantly different for nonrural and rural students. 
The nonrural and rural students ranked the three variables the same in degree of importance. The students placed the most importance on "Find the right person to marry" followed by "Raising a family" and "Live close to parents and relatives."

The literature reported that youth in a rural setting may have more conflicting aspirations. Hektner (1995) found that the students' feeling about living close to family come in conflict with the students' aspirations of leaving for educational or career opportunities. The students in Ley's (1996) study had a mean of 1.93 for the variable, "Live close to parents and relatives," which was similar to the study done in AEA 4 where the students reported a value of 1.98 for nonrural students and 1.92 for rural students.

There were no differences for Research Question 4 except for the variable, "Find the right person to marry." There was a significant difference between nonrural and rural students in the degree of importance expressed by the students. Rural students placed significantly more importance on "Find the right person to marry."

There was no difference in the frequency distribution for the other family concerns listed between rural sudents who live in the country and those who live in town

\section{Research Question 5}

Research Question 5 stated that "There will be no difference in the frequency distribution for a successful adulthood of rural students who live in the country and those who live in town." Table 93 showed the response of nonrural and rural students to location factors that could affect the students' adulthood. The means ranged from 2.14 to 2.63 , which was between "Somewhat important" to "Not important." The students who lived in the country were significantly different from the students who lived in town for four of the five variables. Rural students placed significantly more importance on the variables, "Live where I now live" and "Live in the country 
on a farm or acreage," than did the nonrural students. The nonrural students placed more importance on "Live in a medium sized city" and "Live in a big city" than the rural students. There was no significant difference between the two groups for the variable, "Live in a small town." The ranking of the variables showed that the nonrural students ranked "Living in a medium sized city" first, and the rural students ranked the same variable second. They placed more importance on living in a medium sized city compared to a small town.

Table 61 showed the perceptions of community for their furure. The importance level showed means that ranged from 1.28 to 2.12 . The rankings were the same for nonrural and rural students. "Trying to do the right thing" ranked first followed by "Help improve and care for the environment," "Voting in elections," "Provide volunteer service in my community," and "Work to correct social and economic problems." There were no significant differences between the nonrural and rural students.

The economic variables were reported in Table 65 and showed that students placed definite importance on "Being able to support myself comfortably" and "Being successful in my job career." "Having lots of money" was somewhat important to both groups and ranked last of the three variables reported in the table. The variable, "Being able to support myself comfortably," was significantly different and more important for the nonrural students than the rural students. The other two variables were not statistically different between nonrural and rural students.

Table 67 showed the importance students expressed about their personal time use in adulthood. There was a significant difference between the nonrural and rural students for the variable, "Travel to places outside the United States." Nonrural students placed more importance on the variable than the rural students. "Staying healthy" was ranked last for the three variables listed in the table. 
The religious desires were reported in Table 75 . The rural students placed significantly more importance for the variable, "Live near a church of my faith," than the nonrural students, but the variable, "Have a spiritually fulfilling life," showed no significant differences between nonrural and rural students. The students placed more importance on the variable, "Have a spiritually fulfilling life," than the variable, "Live near a church of my faith."

The Ley (1996) study showed that students placed a premium on the economic variables, and the results in AEA 4 were consistent with what has been reported in the literature. The students in the AEA study placed more importance on "Enjoying my spare time" (1.16) than the students in the Ley study (1.32). The AEA 4 students placed more importance on the religious desires in adulthood than the students in the Ley study.

Research Question 5 was rejected for all of the location variables except "Live in a small town," where the difference between nonrural and rural students was not significant. Research Question 5 was rejected for the religious variable, "Live near a church of my faith," but not for the variable, "Have a spiritually fulfilling life."

Research Question 5 was not rejected for the economic variables except the variable, "Be able to support myself comfortably." The nonrural students placed significantly more importance on the variable than the rural students.

\section{Research Question 6}

Research Question 6 stated that "There will be no difference in the frequency distribution for the educational levels of the fathers and mothers of the rural students who live in town and those who live in the country." Tables 28,29 , and 30 showed the mothers' and fathers' educational levels. Fifty-five and two-tenths percent of the fathers and $54 \%$ of the mothers had a level of education of high school or below. The fathers living in the country had less education 
than the fathers living in town. A chi-square analysis showed significant differences between the educational levels of fathers living in town had more education than the fathers living in the country.

Of the mothers living in the country, $45.6 \%$ of them had an education beyond high school, and $43.9 \%$ of the mothers living in town had an education beyond high school. The mothers living in the country had more additional education beyond high school than the fathers living in the country. A greater percentage of the mothers living in the country had a 4-year degree (20.1\%) than the mothers living in town (14.9\%). The differences between the mother's educational level in town and the country were not significantly different at $p<.05$ but were statistically different at $\mathrm{p}<.06$.

The literature revealed that the educational attainment of the parents had a definite effect on the educational aspirations of the students, especially the mother's educational attainment (Thompkins \& Deloney, 1994). The AEA 4 study showed that the mother's educational attainment was higher than the father's and was not different than the mothers living in town. The high educational aspirations of the students in AEA 4 were consistent with the positive correlation of the mother's educational level and the student's educational aspirations.

There were differences for fathers, but the mothers were not different. There was no difference in the frequency distribution for the educational levels of the mothers of the rural students who lived in town and those who lived in the country, but there was a difference in the frequency distribution of educational levels of fathers of the rural students who lived in town and those who lived in the country. 


\section{Research Question 7}

Research Question 7 stated that "There will be no difference in the frequency distribution for program track among those rural students who live in the country and those who live in town." Table 87 showed the frequencies and rank of the expected programs of study of nonrural and rural students. A chi-square analysis showed a significant difference between the nonrural and rural students. The first ranked program of study for both groups was "Business/Marketing/ Accounting/Management," and the second ranked program of study was "Education" for the nonrural students and "Agriculture" for the rural students. The programs of study that showed differences of $2.5 \%$ or greater between nonrural and rural students were "Agriculture" and "Engineering, Architecture, and Mathematics," which were preferred by the rural students. The nonrural students preferred by more than $2.5 \%$ the programs of study of "Business/Marketing/ Accounting/Management," " Education," and "Political Science, Pre-law, and Foreign Language."

The rural students ranked as their first choice for Program of Study the area of "Business/ Marketing/Accounting/Management" followed by "Agriculture," followed by "Health-Pre-Med, Nursing, Chiropractor."

The nonrural students ranked "Business/Marketing/Accounting/Management" as their first choice for Program of Study followed by "Education" followed by "Health-Pre-Med, Nursing, Chiropractor."

The O'Dell (1986) study in Ohio showed that students ranked "Business" number one followed by "Engineering" and "Health Science" as their intended programs of study. The National Center of Educational Statistics of the U.S. Department of Education (National Center for Educational Statistics, 1995) reported that business management was the most popular undergraduate major and was selected by $21 \%$ of college students in 1994. The AEA 4 study showed 
that "Business/Marketing/Accounting/Management" ranked number one as the intended area of study by $15.7 \%$ of the students.

There was a statistically significant difference between nonrural and rural students for program track.

\section{Research Question 8}

Research Question 8 stated that "There will be no difference in the frequency distribution for grade point average of those who live in the country and those who live in town." Table 5 showed the frequency of distribution of the grade point averages of the students by where they lived. The students who lived on small farms reported the greatest percentage of the GPA range $3.5-4.0$ of $39.7 \%$ followed by $32.8 \%$ for the students living on large farms and $30.9 \%$ for the students living on acreages.

An ANOVA analysis revealed no statistically significant differences between the GPAs of students based on where they lived. An independent t-test comparing the means of nonrural and rural students showed no statistically significant difference of GPAs between the two groups.

The O'Dell (1986) study reported that $16 \%$ of the students reported GPAs of 3.5-4.0. The GPA range $3.5-4.0$ in this study ranged from $21.4 \%$ to $39.7 \%$ for the different locations of where the students lived in the AEA 4 study.

There was no difference in the frequency distribution for grade point average of those who lived in the country and those who lived in town.

\section{Research Question 9}

Research Question 9 stated that "There will be no difference in the frequency distribution for those students who plan to obtain additional education of those rural students who live in the 
country and those who live in the town." Table 78 showed that $90.5 \%$ of all of the students in the study planned to attend a "college, university, trade, or business school" after high school. The table showed that $89.3 \%$ of the rural students planned to do the same. An analysis of the means using an independent t-test showed no significant difference between the nonrural and rural students for their plans to obtain additional education. The literature showed lower education aspiration levels for rural and urban students, and rural students were reported to have lower aspirations (Khattri, Riley, \& Kane, 1997). "Rural youngsters do not aspire to post-secondary opportunities as frequently as either urban or suburban residents do" (Cobb et al., 1989, p. 13). The literature also showed that $6 \%$ of students in rural areas and $3 \%$ in urban areas had no plans to attend college (Snyder, Hoffman, \& Geddes, 1996). The AEA 4 showed that $3.3 \%$ of the students in rural areas and $1.9 \%$ of the students living in town (they are by definition still rural students) had no plans to attend college.

There was no difference in the frequency distribution for those students who plan to obtain additional education of those rural students who live in the country and those who live in town.

\section{Research Question 10}

Research Question 10 stated that "There will be no difference in the frequency distribution for the socioeconomic status of parents of rural students who live in the country and those who live in town." Table 14 showed the self-reported socioeconomic condition of students' parents. A chi-square analysis showed a statistically significant difference between parents of nonrural and rural parents. Table 16 showed the socioeconomic status of the students according to where they lived. The three categories of "Struggle from month to month," "Below average income," and "Average income" were combined. The combined categories revealed that $92.4 \%$ of the small farm students, $87.5 \%$ of the students living in apartment, $82.7 \%$ of the students living on an 
acreage, $82.2 \%$ of the students living on a large farm, and $78 \%$ of the students living in town assessed their socioeconomic status as average or below.

The two categories of "Struggle from month to month" and "Below average incomes" were combined. The students living in apartments had the highest percentage in the new category (37.5\%) with three students reporting. Seventeen and two-tenths percent of the students living on acreages, $17.8 \%$ of the students living on large farms, $15.1 \%$ of the students living on small farms, and $14.3 \%$ of the students living in houses in town reported their socioeconomic condition as "Below average income" or below.

Table 17 showed the results of an analysis of variance of the students' socioeconomic status based on where they lived. The means of the students living in apartments, small farms, and large farms were statistically different.

Table 18 showed that there were statistically significant differences in self-reported socioeconomic status between nonrural and rural parents as reported by the students. The rural students had a significantly lower self-reported socioeconomic status than the nonrural students. The rural students reported in Table 14 that $86.5 \%$ of their parents had an average income or below, and $79 \%$ of the nonrural students reported their socioeconomic condition as average or below.

The literature has reported extensively on socioeconomic factors, especially poverty, as important contributors to student aspirations or lack thereof (Kattri et al., 1997). The students living in the country reported themselves as having a below average income. The correlation (Cramer's V) between socioeconomic status and educational aspirations was negligible (.09).

There was a difference in the frequency distribution for the socioeconomic status of parents of rural students who lived in the country and those who lived in town. 


\section{Research Question 11}

Research Question 11 stated that "There will be no difference in the frequency distribution for community perceptions of those rural students who live in the country and those who live in town." Tables 55-60 showed the community perceptions of the rural students who lived in the country and who lived in town. Students who lived in the country on acreages or farms had a more positive perception of their communities than the students who lived in town. The community attributes in Table 55 of "An average place to live," "A good place to live," and "A great place to live" were combined. The percentages of students responding to one of the three categories showed a ranking of $92.4 \%$ of the students living on a small farm, $91.9 \%$ of the students living on a large farm, $89.1 \%$ of the students living on an acreage, $86 \%$ of the students living in a house in town, and $40 \%$ of those residing in an apartment. An analysis of variance in Table 56 showed that the students living in an apartment were significantly different than the other groupings of living locations. Table 57 showed the frequencies of the nonrural and rural students, and Table 58 showed the results of an independent t-test which showed that the rural students had a significantly more positive perception of their community than the nonrural students.

Rural researchers have suggested that students in rural communities are linked to communities (Theobald \& Nactigal, 1995). The NIRAS study showed that a significant difference existed between students who live in town and those who lived in the country.

Researchers have argued that "the assets of rural communities include the presence of strong community connections, a sense of localism, and a value of place..." (Khattri, Riley, \& Kane, 1997, p. 86). Others have argued that the communities are tightly linked which reflects through the various informal community decision-making mechanisms (e.g., De Young, 1994; Howley \& Howley, 1995; Pelavin Research Institute, 1996). Rural researchers suggested that 
schools in these communities were tightly linked to the communities they served (e.g., Theobald \& Nachtigal, 1995). The NIRAS results showed that students did view their community positively except for the apartment dwellers, and there were differences in community perceptions between nonrural and rural students.

There was no difference in the frequency distribution for community perceptions of those rural students who lived in the country and those who lived in town. Rural students had a more positive perception of their community than the nonrural students.

\section{Research Question 12}

Research Question 12 stated that "There will be no difference in the frequency distribution for work status of those rural students who live in the country and those who live in town." Table 10 showed the employment stans of nonrural and rural students. A chi-square analysis showed a significant difference in employment level per week between the nonrural and rural students. The percentage of rural students working for pay was greater than the nonrural students in the "11-20 hours" and " $>20$ hours" categories. When the two categories were combined, $54.6 \%$ of the nonrural students and $61.2 \%$ of the rural students worked for pay eleven or more hours per week.

Table 13 showed the reasons the students selected as reasons for working. A greater percentage of rural students (37\%) reported that they worked because they needed the money for their future plans compared to the nonrural students (30.8\%). A chi-square analysis showed the reported differences were significant between nonrural and rural students.

The literature reported that rural students work more than their urban counterparts (Khattri et al., 1997), and in the AEA 4 study, the students who lived in the country worked more hours than the students who lived in town. 
There were significant differences in the frequency distribution for work status of those rural students who lived in the country and those who lived in town. The rural students worked more hours than the nonrural students.

\section{Research Question 13}

Research Question 13 stated that "There will be no difference in the aspirations between private school students and those who attend public schools." Much of the same data that were examined for the rural and nonrural students was examined for the private and public school students in the AEA 4 study.

The size of the schools was shown in Table 2. The average senior class size in the private schools was 63 students and 61 students in the public schools. The gender distribution was similar between the two groups, $53.1 \%$ male and $46.9 \%$ female for the public schools, and $51 \%$ male and $49 \%$ female for the private schools. The seniors in both groups of schools were predominantly Caucasian, $99 \%$ in the private schools and $96.8 \%$ in the public schools.

Spalding Catholic was a parochial school, a school controlled and supported by the Roman Catholic church. The remaining three schools were private schools which were controlled and supported by separate societies that had an interest in and supported the philosophies that guided each of the schools. Churches did not administer the schools. The schools were founded and have been guided by people who adhere to a world view promoted by various church denominations present in the region (Christian Reformed, Protestant Reformed, United Reformed, and Netherlands Reformed) who believe that all of life, including education, is subject to the understanding of what it means to be a Christian. All disciplines and subjects are developed within that philosophical premise. 
The personal characteristics of the private and public school students were examined, and there were no significant differences in gender, race, or self-reported grade point averages. There was a statistically significant difference between where the private and public school students lived. Table 7 showed that a greater percentage of the private school students lived in the country (56.1\%) than the public school students (37.1\%). Church attendance was statistically different between the private and public school students. Table 9 showed that private school students attend church services more frequently than public school students. Tables 11 and 12 showed significant differences in the amount students worked and the reasons they worked. A greater percentage of private school students worked in the "1-10 hours per week" and "10-20 hours per week" categories, and a greater percentage of public school students did not work and worked " $>20$ hours per week." The private school students reported a greater percentage for "I need money for future plans (college, business, car)" (41.4\%) than the public school students $(30.8 \%)$.

The family characteristics of the private and public school students were examined. Table 15 showed frequency of the students' self-reported socioeconomic status. There was no statistically significant difference in the self-reported socioeconomic status between private and public school students which was determined by an independent $t$-test. There was a significant difference in the parents' marital status which was shown in Table 21 . Ninety and four-tenths percent of the parents of private school students were "Married, never divorced," and $74.8 \%$ of the parents of public school parents were "Married, never divorced." The private school students came from larger families. Table 24 showed that $55.8 \%$ of the private school students reported three or more siblings compared to $35.2 \%$ of the public school students which was statistically significant. The educational background of the fathers and mothers for private and public school students was not significantly different. The farming history of the grandparents showed in Table 
25 that significantly more of the private school students had grandparents who were farmers (86.4\%) than the public school students (78.8\%). Table 25 showed the frequencies of the students whose fathers were farmers. The differences were significantly different. Forty-two and fourtenths percent of the private school students and $32.8 \%$ of the public school students had fathers who were farmers.

The students' educational background was examined. The private school students had minimal agricultural course work since agriculture courses were not part of the curricula of the private schools. There was also minimal FFA involvement because FFA was not part of the curricula. Table 38 showed the participation levels of the private and public schools. The involvement in 4-H by the private and public school students was shown in Table 45 . A significantly greater number of public school students (27\%) had participated in 4-H than the private school students $(14.7 \%)$. Table 47 showed the differences for involvement in extracurricular activities. Significant differences were shown for participation in sports $(83.9 \%=$ public; $73.2 \%=$ private $)$ and for participation in musical activities $(88.3 \%=$ private; $68.3 \%=$ public). The differences in gender involvement in extracurricular activities were examined for private and public schools. For private schools, more females participated in musical activities ( $93.8 \%$ of the females; $85 \%$ of the males) and were officers in a church, school, or community group (55.7\% of the females; $38.6 \%$ of the males). For public schools, more females participated in musical activities (83.9\% of the females; $54.9 \%$ of the males) and a greater percentage of males participated in sports activities $(87.1 \%$ for the males; $80.4 \%$ for the females). Tables 52 and 53 showed that there were significant differences for taking physics or chemistry (public $=66.9 \%$; private $=57.4 \%$ ) and for taking technical drawing and shop (public $=54.8 \%$; private $=41.9 \%$ ). The distance students lived from school was included in the educational background because distance affects the involvement of students in extracurricular 
activities. Table 54 showed significant differences between private and public school students. The students in private schools traveled greater distances to attend school. Twenty-six and twotenths percent of the private school students traveled 16 or more miles to attend school, and $4.3 \%$ of the public school students traveled 16 or more miles to attend school.

The student perceptions and desires were shown using various variables. Table 60 showed that private school students had a statistically significant more positive perception of their community than public school students. Table 61 showed future community desires, and private school students placed more importance on "Voting in elections" than public school students. Table 64 showed variables that were factors that would improve their future opportunities. Public school students placed significantly more importance than private school students for the variables, "Have college courses available over the Internet," "Have better paying jobs in the community," "Share teachers and courses with other schools," and "If I lived in a city" than private school students. The educational perceptions and attitudes of the students concerning their education were shown in Tables 104 and 106. Private school students rated the quality of their education significantly better than the public school students. The variables in Table 104 showed that private school students were significantly different and reported more positively on the variables of "Students show respect for teachers, I feel safe in school," and "My courses help me understand my everyday life." The economic variables were shown in Table 66 , which showed that private school students placed significantly less importance on the variables, "Be able to support myself" and "Making lots of money." For the personal time factors, public school students placed significantly more importance on "Travel outside the U.S." than private school students. Table 70 showed the personal self-perceptions of the seniors, and the public school students reported more agreement with the dependent variable, "I am dependable," than the private school students. The parental perceptions were shown in Table 72. Private school students 
had a significantly more positive perception of their parents, but the students in public schools reported that their parents were more positive about them attending college after high school than was reported by the students in private high schools. Table 74 showed no significant differences about family concerns for a successful adulthood between private and public school students. The private school students placed significantly more importance on future religious desires than public school students, which was shown in Table 76.

The future educational aspirations of the private and public school students showed no statistically significant difference in their intentions to attend a college, university, or trade school after high school. There was a statistically significant difference between private school and public school students in the type of education that was planned. The public school students had a greater percentage of students who intended to pursue a 2-year community college, then 4-year college or university than the students from the private schools. Table 86 showed the differences between the private and public school students in their aspirations for program of study at $\mathrm{p}<.08$ were not significantly different. Questions in the questionnaire asked the students to respond to the importance of a 2-year degree and a 4-year degree. Table 90 showed that there was no significant difference in the aspirations between the private and public school students for obtaining a 2-year degree, but there was a significant difference between the student aspirations for a 4-year degree. The public school students expressed more importance for obtaining the 4year degree than the private school students. There were no significant differences between the two groups of students in their aspirations to enter the military. There was no significant difference between the two groups for the occupation desired by age 30 , but there was a significant difference in the occupations that they reported they would probably have by age 30 . The differences between the private and public school students that exceeded $2.5 \%$ were Management (private school students percentage declined $4.5 \%$ from what they reported as their 
occupation desired), Compurer and Mathematical, Healthcare Practitioners and Technical, and Office and Administrative Support (private school students percentage increased by $2.8 \%$ from occupation desired), Construction and Extraction, Uncertain, and Housewife.

There was a significant difference between the private and public school students for the indication of where they would live by age 30, which was reported in Table 111. A greater percentage of private school students than public school students indicated that they would "Live in the local area" (18.9\% and $9.5 \%)$ or "Within 75 miles" (16.8\% and $12.1 \%)$. There were no significant differences between private and public school students for the importance of pursuing an agriculturally related career.

The potential barriers to educational and occupational aspirations were reported for private and public school students. Factors related to rural location barriers were shown in Table 96. Private school students viewed "Lack of jobs in my community" as significantly less of a barrier than the public school students. Financial barriers were shown in Table 15, and no significant differences were reported between private and public school students in their self-reported socioeconomic status. There was a significant difference for one of the personal qualities in the questionnaire. Private school students viewed themselves as significantly less dependable than public school students, which was shown in Table 70. There were also differences between the private and public school students concerning parental qualities, which was reported in Table 72. Private school students reported that they more strongly agreed that their parents were positive role models and their parents liked their school. Public school students reported that their parents more strongly agreed that going to college was important than the private school parents, and the difference was statistically significant. Table 102 reported that public school students' "Lack of transportation" as significantly more of a barrier than private school students. There were significant differences between the private and public school students pertaining to perceived 
educational barriers. The private school students in Table 104 reported significantly more agreement with "Students show respect for teachers," "I feel safe in school," and "My courses help me understand my everyday life." Table 106 showed that private school students perceived their education to be of higher quality than was reported by the public school students.

There were significant differences in aspirations reported between private and public school students and the factors that affected their aspirations. 


\title{
CHAPTER VI. SUMMARY, CONCLUSIONS, IMPLICATIONS, AND RECOMMENDATIONS
}

\author{
Summary \\ The purpose of the study was to identify and describe the educational, occupational, and \\ personal aspirations to a fulfilling adulthood of rural high school students located in Cherokee, \\ Lyon, O'Brien, Osceola, and Sioux counties which make up the educational district called Area \\ Education Agency 4 (AEA 4) in Iowa, and identify disadvantages and barriers that may affect \\ their educational and occupational aspirations. \\ The literature provided guidance, and the study used methodologies and instruments that \\ were used in previous studies to develop the study and design the instrument. Hypotheses were \\ derived from the literature and were developed to provide educational insight and understanding \\ for a specific geographic part of Iowa, of rural education, and of agricultural education in the \\ context of rural education in northwest Iowa. \\ An instrument was developed that used questions derived from the instrument used for the \\ Northwest Regional Educational Laboratory 1996 Youth Aspiration Study, from an instrument \\ used by the National Center for Student Aspirations at the University of Maine, and the High \\ School and Beyond instrument used by U.S. Department of Education, and the Indiana Youth \\ Poll. The final instrument was developed and titled the Northwest Iowa Rural Aspiration Study \\ (NIRAS). \\ A descriptive study was developed to describe incidence and distribution of aspirations and \\ perceptions in AEA 4. A census study was developed to include an entire population of high \\ school seniors in a specific geographic region that was rural, a region extensively involved in \\ production agriculture, most of the participating schools had agriculture programs, and all of the
}


schools were considered by definition to be rural schools. The presence of private schools in AEA 4 provided the opportunity to examine and describe the private schools in the context of a rural agricultural area.

AEA 4 consisted of seventeen schools-thirteen public schools and four private schools. All of the schools participated in the study, and the study was conducted in the spring of 1999 with the permission and cooperation of the high school principals and superintendents. The NIRAS instrument was examined for validity and reliability and was subsequently administered to high school seniors by the principal or his or her designate in each of the schools. The AEA 4 agency cooperated in the study by distributing and collecting the instruments. The Statistical Package for the Social Sciences (SPSS ${ }^{\circledR}$ ) was used to examine the data.

The findings showed that significant differences were reported for variables in the study between students who lived in town and the students who lived in the country. Much of the literature reported rural and urban differences for educational and occupational aspirations, attitudes about family, community, and their education, differing perceptions about barriers to a student's future, and attitudes about the future. The literature reported difficulties with the definitions of rural as being too broad or not having enough accuracy to deal with rural issues and problems. The findings found that differences occurred between the students who lived in town (defined as nonrural in this study) and students who lived in the country (defined as rural in this study). Many of the significantly different findings between nonrural and rural in this study concurred with the differences that were reported in the national studies that occurred between rural and urban even though all of the students in the AEA 4 study were identified as rural students by commonly used definitions.

The students of nonrural parents reported that their parents placed more importance on attending a college than the parents of rural students. Rural students reported less importance on 
supporting themselves than nonrural students. Rural students had lower levels of educational aspirations than the nonrural students. Rural students had significantly more siblings, had more positive perceptions about their communities, and had more positive perceptions about their parents than nonrural students. These findings were similar to differences that have been reported in the literature for urban and rural students. The findings of this study support the discussion that the definitions are somewhat problematic since the study found that similar urban/rural differences that have been reported in the literature occurred in an all rural area, and the differences that were found were based on where the student lived within the rural community. The barriers to the educational and occupational aspirations described in the literature may be more a function of location within a community than a function of rural and urban as reported in the literature.

The findings of the study showed that there were no significant differences between nonrural (students who lived in town) and rural (students who lived in the country) students in their aspirations for continued education, but rural students were found to have lower aspirations in the degree level aspired to for their education.

The FFA membership in AEA 4 consisted of $35.9 \%$ nonrural students and $64.1 \%$ rural students. The distribution of the FFA membership between the students who lived on an acreage, small farm, and large farm were nearly the same. Students who had taken agriculture courses or participated in FFA had lower educational aspirations than students who had not taken agriculture courses.

The students in AEA 4 had a high frequency of intention to continue their education after high school. Ninety and eight-tenths percent of the seniors had intentions of continuing their education. The results showed that more females planned to continue their education than males which supports the national occurrence that the number of students who plan to continue their 
education is increasing, but much of the increase has been attributed to an increased number of females who plan to continue their education.

The top ranked intended area of study reported by the seniors was the area of business. The category included business, marketing, accounting, and management aspirations. The second ranked program of study was education for the nonrural students and agriculture for the rural students. The third ranked intended program of study was the health area which included the preprofessional programs of pre-med, pre-chiropractic, pre-pharmacy, and the programs of nursing. If all health professions are combined (to include physical therapy, athletic trainer, equipment technology, dental assistant, and other support areas), the combined group is top ranked for rural students, and second ranked for the nonrural students. There were significant differences between the nonrural and rural students in the programs of study that they intended to follow.

The seniors reported on the factors that could improve their future opportunities. There were no significant differences between nonrural and rural students, but the students did place importance on having more financial help to obtain schooling, have better paying jobs in their community, have more job training courses, and have access to college courses while in high school. The seniors reported on the rural location factors, the personal attitudes towards their school and their education, and external factors that may be barriers to their aspirations. There were no significant differences between nonrural and rural students.

There were significant differences between the private and public school students in family characteristics and backgrounds, educational backgrounds, community perceptions, educational perceptions, and economic desires. Self-perceptions were slightly different. There were no significant differences in self-reported socioeconomic status nor in the personal attitudes and perceptions that could be barriers to educational and occupational aspirations. 
There were significant differences in the perceptions of their schools and the quality of their education. Private school seniors reported more positive attitudes about the quality of their schools and the educational process.

A significantly greater number of private school seniors had farm backgrounds and lived in rural areas than public school seniors. However, the private schools did not have agriculture programs that served the students.

There was no difference between public and private school seniors in their aspirations to continue their education, but there was a significant difference in the level of educational aspirations. Public school seniors had significantly greater aspirations for a 4-year degree than private school seniors.

A significantly greater percentage of the private school students indicated that they would probably live in the local area or within 75 miles of where they now live than the public school seniors.

A significantly greater percentage of the public school seniors indicated that they would probably live more than 200 miles from where they now live.

\section{Conclusions and Implications}

The following conclusions and implications are based on the interpretation of the data presented in this study.

Conclusion 1: The differences in aspirations, perceptions, and potential barriers reported in the literature for rural students and urban students were noted in this study of all rural students, and the differences that occurred were due to where the rural students lived in the context of their community, in town or in the country. 
Implications: The perceptions of the communities by the nonrural and rural students were significantly different, and the extent of the education planned by the students was significantly different. The discussions of traditionally disadvantaged students in rural areas may not accurately portray where the differences may exist in rural areas. This study found the differences were due to location relative to where the person lived in the community, in the coumtry or in town.

The differences found in this study reinforced the need to more accurately define rural and to establish criteria on a state and national basis that improves uniformity and provides more accurate descriptive qualities for rural areas and rural schools.

Conclusion 2: The educational aspirations of the seniors of AEA 4 and their intentions to continue their education were very high, and there were no significant differences between nonrural and rural students in their intentions to continue their education after high school, but the extent of educational aspirations were significantly different between the nonrural and the rural student. The frequency of the rural students was significantly less than the nonrural students for aspiring to a 4-year degree.

Implications: The literature reported that rural students had lower educational aspirations. This study showed no difference in the students' intentions to continue their education, but a lesser percentage of rural students aspired to a 4-year degree than nonrural students. The fathers in this study who lived in the country had significantly less education than the fathers who lived in town. There were no significant differences in the educational levels of the mothers in nonrural and rural areas. The literature reported that mothers may be the more influential parent in affecting a student's aspirations, but that indication was not evident in this study. There was a low correlation between the parent's educational level and the student's aspirations for obtaining a 4year degree. 
The students who resided in the country took as much calculus, trigonometry, geometry, physics, and chemistry, but significantly less foreign language. The rural students also had similar GPA's compared to the nonrural students. The study reported that differences in educational aspirations occurred within rural students based on where they lived, but it was not clear why those differences in the extent of their educational aspirations occurred.

Conclusion 3: The self-reported socioeconomic status of the seniors showed that the students who resided in apartments in town reported the lowest level of economic status followed by those who resided on small farms followed by those who resided on large farms.

Implications: AEA 4 was a uniform rural area including farms and small towns. The students who resided on the farms and the students in apartments in town viewed their parents' income as below average. The students who resided on acreages and who lived in houses in town considered themselves to have an average economic status. The students who lived on farms engaged in production agriculture (small and large farms) viewed themselves as disadvantaged economically when compared to the parents of their fellow students. The perception of economic well-being by the seniors was lower and was consistent with what has been reported for rural areas in general and has been consistent with the recent downturns in the agricultural economy for crops and livestock. It was unclear why the students who lived on acreages were not included with the small farms or the large farms. It can be speculated that most people who resided on the acreages did not derive a significant amount of their income from agricultural production nor did they depend upon agricultural production for their income. The socioeconomic status of people who reside on acreages and the role they play in rural communities is not well understood. 
Conclusion 4: The characteristics of the rural schools that were investigated in this study were generally uniform.

Implications: The schools were located in northwest Iowa which is in a rural portion of the state that was uniform in school size, ethnicity, agricultural production, FFA availability, availability of agriculture programs in high school, and were rural by definition. The fathers were educated in the local area; $82.5 \%$ of the fathers residing in the rural area and $61.8 \%$ of the fathers who lived in town were educated in the school their children attended or a school within twentyfive miles of where their son or daughter attended. The mothers were similar; $65.6 \%$ of the mothers residing in the rural areas and $61.6 \%$ of the mothers residing in town were educated in the school their son or daughter attended or a school within twenty-five miles of where their son or daughter attended. The communities were quite stable, and the communities and schools had histories of people remaining in their local communities.

Conclusion 5: The nonrural students from AEA 4 had the highest aspiration to live in a small city (Sioux Falls or Sioux City) and then a small town. The rural students had the highest aspirations of living on a farm or acreage followed by live in a small city and then a small town.

Implications: The students had greater aspirations for living in a city that existed close to where they now live before they had aspirations for living in a small town. The towns in AEA 4 that were familiar to the students ranged from Sioux Center with a population of slightly over 5,000 people to such towns as Alvord with slightly over 200 residents. The students expressed greater aspirations of living in either Sioux Falls or Sioux City (populations of over 80,000 residents). The students aspired more to living in a small city rather than to live in small towns.

The rural students aspired first to live in the country on a farm or acreage and then in a small city. There was no clear indication of why the students did not aspire to live in their local 
communities. The rural students expressed positive perceptions of their community, but they aspired more to live in a small city over their local communities. The reasons were not clear.

Conclusion 6: Students who enrolled in agriculture courses and/or participated in FFA had lower aspirations to continue their education than students who had not enrolled in agriculture courses or had not participated in FFA.

Implications: The students who participated in FFA and/or took one or more agriculture courses expressed intentions between "Definitely attend" and "Likely attend" a college, university, or trade school after high school, but their intentions were significantly less than the students who had not taken agriculture courses or who had participated in FFA. Eighty-three and one-tenth percent of the students who had some degree of FFA participation planned to continue their education, and $92 \%$ of the students who did not participate in FFA planned to continue their education. The difference is not a solely rural situation because $35.9 \%$ of the students who had participated in FFA lived in town. There were no significant differences in the educational aspirations of the students who participated in 4-H. The study did not reveal a clear reason why the students who participated in FFA had lower educational aspirations.

Conclusion 7: The extracurricular participation of nonrural and rural students were similar except that rural students were more frequently officers in school, church, or community groups.

Implications: The rural students were not at a disadvantage in their participation in extracurricular activities. They demonstrated significantly more leadership by serving as officers in school, church, or community groups. There were significant differences based on gender. There was significantly more male participation in sports, and there was significantly more female 
participation as an officer of a group, females had a greater music participation, and females more frequently participated in a play or academic competition.

Conclusion 8: Rural students are employed for more hours for pay than nonrural students.

Implications: The hours per week that students were employed for pay more than eleven hours per week was $54.6 \%$ of the nonrural students and $61.2 \%$ of the rural students. The frequency was significantly different for the nonrural and rural students. The amount of time the students worked and the number of students who performed the work indicated that the students had a significant amount of time dedicated to earning money.

The reasons that students gave for working was that the students needed money for future plans (college, business, car). The rural students were significantly different because they worked more hours and they more frequently indicated that they needed money for future plans.

Conclusion 9: The marital status of the parents of rural students indicated that a significantly greater percentage of rural parents were married and never divorced than nonrural parents.

Implications: The study showed that $84.2 \%$ of the parents of rural students and $74.6 \%$ of the nonrural students had parents who were married and were never divorced. The rural students experienced a greater degree of marital stability in their home situations than the nonrural students.

Conclusion 10: A significantly greater frequency of the students in the private schools came from farm backgrounds and had agricultural interests. 
Implications: A greater percentage of private school students (56.1\%) lived in the country on acreages, small farms, and large farms than private school students (37.2\%). A significantly greater percentage of the private school seniors had fathers who were farmers. The private school students ranked "Agriculture" as third for their intended program of study.

The presence of agricultural education in the private schools was minimal in the private schools even though the agricultural backgrounds of the students was greater than in the public schools where all but one school had agricultural course offerings. Agricultural course offerings should be examined in the private schools to better serve the agricultural needs in the region included in AEA 4.

Conclusion 11: The students from the public schools expressed greater intentions of living more than 200 miles away from the local community than private school students, and a greater percentage of private school students expressed intentions of living in the local area and for living within 75 miles of the local area.

Implications: The private school students expressed significantly more positive perceptions of their community than public school students, they expressed greater intentions of returning to the local community, and they felt more positive about their education. The private schools should be assessing their role in the community and how the curriculum integrates with the future needs of the community.

Conclusion 12: Religious factors and desires are significant to the development of the aspirations of the students in AEA 4.

Implications: The students in AEA 4 placed importance to having a spiritually fulfilling life and living near a church of their faith. Rural students placed significantly more importance on 
living near a church of their faith than the nonrural students, and the private school students placed significantly more importance on having a spiritually fulfilling life and living near a church of their faith than the public school students. The fact that students placed importance of living near a church of their faith would influence where they would be willing to live in the future.

Conclusion 13: Private school students had lower aspirations for the level of continued education than the public school students.

Implications: The private school students expressed less of an intent to pursue a 4-year degree than the students from the public schools. Their intentions were similar to the students from rural areas and may be partly explained by the greater percentage of rural students who attend the private schools.

Conclusion 14: The students in AEA 4, both private and public, did not report significant barriers because of where they lived, their high school education, nor external barriers as impediments to their educational and occupational aspirations. A lack of money for education was the highest ranking barrier which was described as somewhat of a barrier.

Implications: The students did not describe the barriers listed for them as significant barriers. The potential barriers that may have existed for personal attitudes and perceptions were not reported as significant barriers by the students. The means for barriers reported in the literature were reported as greater barriers than the means that were reported for the students in AEA 4. The AEA 4 students were similar with other studies because they ranked a "Lack of money for education" as the most important barrier, but the AEA 4 students reported it as less of a barrier than students in a national study. 


\section{Recommendations}

1. The rural schools in this study should assess how the needs of the students who live in the country (rural) are being met in the educational process since the extent of their educational aspirations was less than their peers who lived in town.

2. The private schools should examine the feasibility of offering agriculture courses in their curricula because of the number of students who have agricultural backgrounds.

3. The agriculture programs in the public schools should examine their curricula to ascertain if the curricula have contributed to the lower educational aspirations of students who took agriculture courses.

4. Over $50 \%$ of the students in the schools in AEA 4 work more than 11 hours per week. The schools should examine the impact that work has on the educational process for curricular and extracurricular activities. The work may be a barrier to the student's education or it may be useful for integration into the educational process.

5. The public schools should examine why their students have a greater reported propensity to leave their communities than the students from the private schools.

6. All the schools in AEA 4 should recognize and acknowledge the role that religiosity plays in the future aspirations of their students and encourage a sensitivity within their schools for that element in the educational process.

7. The private schools should examine their educational programs to ascertain why their students aspire to less education than the students from public schools in AEA 4.

8. The students in AEA 4 have placed more value on personal and career aspirations than the more selfless concern for the common benefit of the community. The schools should examine how civic mindedness can be improved in the educational process. 


\section{Recommendatious for Further Research}

1. A study should be developed that is more inclusive of more if not all of lowa. The census study in AEA 4 was not representative of other parts of Iowa, and since much of Iowa is rural, a study should be designed for all of Iowa.

2. A research design and instrumentation should be developed that will allow for the development of predictive models.

3. Future research should include the investigation of the role private schools, especially private rural schools, play in affecting the development of students and the rural communities.

4. A study should be designed that more closely examines the effect of the location of where the student lives and how location affects the development and aspirations of the students.

5. The study should be repeated in AEA 4 to determine the consistency of the student attitudes and perceptions.

\section{Implications and Significance to Education}

There are significant differences in perceptions and aspirations of high school students that are affected by where a student lives in relationship to their community. Students who live in the country are significantly different than the students who reside in town for various qualities that have been reported in this study. The differences provide some very important opportunities and challenges to the educational process. The location of where a student lives does affect their perceptions and their aspirations for the future.

The students who attended private and public schools in AEA 4 had high aspirations to continue their education, had good perceptions about their communities, and performed well 
academically, and had positive perceptions concerning their education. Yet there were significant differences between the students for various factors and qualities that were investigated in the study. The differences can be examined and mutual support can be given to enhance the mission of each of the schools in AEA 4 which should enable each school to improve and better serve the student and their respective communities. Private and public schools have provided different resources that have positively impacted the development of the local communities.

The study provided an opportunity to examine the context for the continued development of agricultural education in the high schools in AEA 4. The aspirations and perceptions of students were different based on where the students lived, and a sensitivity to the differences can be positively used to enhance and improve agricultural education in rural areas. The future educational aspirations of agricultural students were different for agricultural students which may be partly explained by the student interests to remain in local communities or by student interest to pursue two-year degrees that may suffice for pursuing careers in their local communities. The information has provided a springboard for discussions that set the direction for educational improvement in AEA 4.

The study raised questions about the development of agriculture programs in the rural schools. The study described the students who had taken agriculture courses in AEA 4. The percentage of students in public schools who had taken an agriculture course was $35.5 \%, 19.4 \%$ had participated in FFA at least one year, and $11.5 \%$ of the public school students had participated in FFA four or more years. The students who had taken agriculture courses had lower aspiration levels for furthering their education.

The data can be examined from a historical context. The National Research Council in 1988 published Understanding Agriculture: New Directions for Education which stated: 
New efforts are needed to reform secondary school agriculture programs to better prepare students for agricultural-sector growth industries. An essential step toward achieving this goal is to fully accept the broadened definition of agriculture education recommended by the committee. In some cases, this will require change in or abandonment of vocational guidelines. Under vocational agriculture, this definition would include greater diversity of career paths, such as scientific research, technology development, medical and social services, finance, law, business, management, and marketing. (p. 32)

Eleven years later, the recommendations of the Research Council should be examined to determine their impact on high school agriculture education in rural schools to determine if agriculture education responded to the need as described by the National Research Council. The study in AEA 4 has provided an incentive to examine the curricula in agriculture programs to reassess the vision, institutional goals, program goals, desired outcomes, and learning activities that shape the course of study that contributed to the aspirations of the students affected by the agriculture program. An assessment can be made to determine if the needs of more students can be met, and if they can be met more effectively. The programs should be examined to determine if inherent factors in the programs have inhibited educational aspirations or conversely, if there are strengths in the agriculture programs that have served the local communities, and that those strengths need additional support and consideration.

The private school students reported a significant agricultural background, and they reported a strong affinity for their local communities. Possibilities should be explored in the educational process that could promote and make agricultural education accessible to all students included in AEA 4.

There has been precedent for agriculture programs that have included private schools in Iowa. The Carroll Community High School and the Kuemper Catholic High School established a partnership that resulted in a joint agriculture program that started in 1992 (Miller, 1995). Consideration and the exploration of the development of agriculture programs in private schools in Iowa may serve an additional pool of students with an agricultural background and interest. 
Also the agricultural communities may be enriched in a more pronounced manner if new ideas, new visions, and cooperative ideas are explored that may provide innovative ways of meeting the future agricultural education needs of all students. 


\section{Information for Review of Research Involving Human Subjects lowa State University}

(Please type and use the attached instructions for completing this form)

1. Title of Project The Educational and Occupational Aspirations and Expectations of Northwest Iowa Seniors

2. I agree to provide the proper surveillance of this project to insure that the rights and welfare of the human subjects are protected. I will report any adverse reactions to the committee. Additions to or changes in research procedures after the project has been approved will be submitted to the committee for review. I agree to request renewal of approval for any project continuing more than one year.

Duane H Bajema

Typed name of principal investigator

Agricnitural Education and Studies Department

294-5872

Phone number to report results

3. Signatures of other investigators V. Wad 732 ile

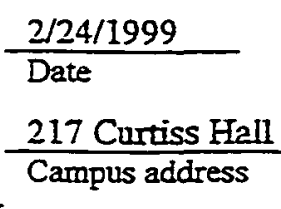

Date

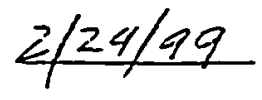

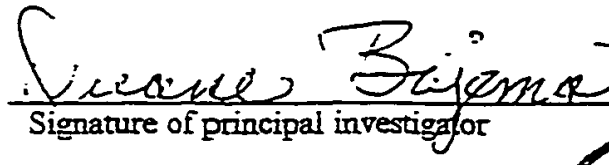

Signature of principal investigajor

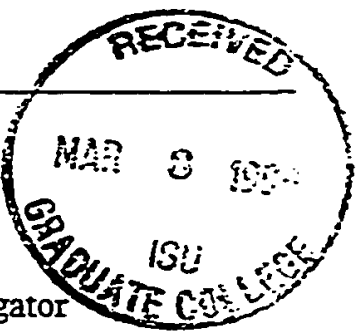

Relationship to principal investigator fit Cis

Graduate Student Advisor

4. Principal investigator(s) (check all that apply)

$\bigotimes$ Faculty

$\square$ Staff

$\otimes$ Graduate student

Undergraduate student

5. Project (check all that apply)

$\otimes$ Research $\otimes$ Thesis or dissertation $\square$ Class project

Independent Study (490, 590, Honors project)

6. Number of subjects (complete all that apply)

\# adnits, non-students: \# minors under 14: \# minors $14-17: \quad 1,130$

\# ISU students: other (explain):

7. Brief description of proposed research involving human subjects: (See instructions, item 7. Use an additional page if needed.)

Stadents in rural schools have been cited as being disadvantaged and of having lower aspirations when compared to urban students. The future educational and occupational aspirations of students may be affected by the fact that the stadents are educated in rural schools in Iowa. A survey will be administered ander the direction of the high school principals or other school official to discover the aspirations of high school seniors. The Area Education Agency 4 was selected because it is a definable unit that has all rwal schools. No incentives have been offered except the principals have been told that they will receive the information as it pertains to their school. No follow-up action is planned at this time.

8. Informed Consent:
(Please do not send research, thesis, or dissertation proposals.)

$\square$ Signed informed consent will be obtained. (Attach a copy of your form.)

$\bigotimes$ Modified informed consent will be obtained. (See instructions, item 8.)

Not applicable to this project.

hto://uww.grad-college.iastate.edufforms/HumanSubjects.doc 
9. Conficientiality of Data: Describe below the methods you will use to ensure the confidentiality of data obtained. (See instructions, item 9.)

The survey will be administered by the high school principal or someone designated by the prinicipal. There will be no names of individual students requested. Only the name of the school is requested. A computer graded bubble sheet (attached) will be used to collect the information. The computer bubble sheets will be destroyed after completion of the dissertation.

The information from the individual schools will remain confidential and will be made available only to the principal of the high school.

10. What risks or discomfort will be part of the study? Will subjects in the research be placed at risk or incur discomfort? Describe any risks to the subjects and precautions that will be taken to minimize them. (The concept of risk goes beyond physical risk and incindes risks to subjects' dignity and self-respect as well as psychological or emotional risk See instructions, item 10.)

There will be no specific risks or discomforts except that the high school seniors will be asked to complete a survey.

11. CHECK ALL of the following that apply to your research:
A. Medical clearance necessary before subjects can participate
B. Administration of substances (foods, drugs, etc.) to subjects
C. Physical exercise or conditioning for subjects
D. Samples (blood, tissue, etc.) from subjects
E. Administration of infectious agents or recombinant DNA
F. Deception of subjects
G. Subjects under 14 years of age and/or $\bigotimes$ Subjects $14-17$ years of age
H. Subjects in institutions (nursing homes, prisons, etc.)
I. Research must be approved by another institution or agency (Atach letters of approval)

If you checked any of the items in 11 , please complete the following in the space below (include any attachments):

Items $\mathbf{A}-\mathbf{E}$ Describe the procedures and note the proposed safety precautions.

Items D-E The principal investigator should send a copy of this form to Environmental Health and Safety, 118 Agronomy Lab for review.

Item F Describe how subjects will be deceived; justify the deception; indicate the debriefing procedure, including the timing and information to be presented to subjects.

Item $G$ For subjects under the age of 14 , indicate how informed consent will be obtained from parents or legally authorized representatives as well as from subjects.

The subjects will be high school seniors, and the information will be collected by the high school principal or a person the principal designates from within the high school.

Items H-I Specify the agency or institution that must approve the project. If subjects in any outside agency or institution are involved, approval must be obtained prior to beginning the research, and the letter of approval should be filed. 
Last name of Principal Investigator Bajema

\section{Checklist for Attachments and Time Schedule}

The following are attached (please check):

12. $\bigotimes$ Letter or written statement to subjects indicating clearly:

a) the purpose of the research

b) the use of any identifier codes (names, \#'s), how ther will be used. and when ther will be removed (see item 17)

c) an estimate of time needed for paricipation in the research

d) if applicable, the location of the research activity

e) how you will ensure confidentiality

f) in a longitudinal study, when and how you will contact subjects later

g) that participation is voluntary; nonparticipation will not affect evaluations of the subject

13. $\square$ Signed consent form (if applicable)

14. $\bigotimes$ Letter of approval for research from cooperating organizations or institutions (if applicable)

15. Data-gathering instnuments

16. Anticipated dates for contact with subjects:

First contact

March. 1999

Month/Day/Year
Last contact

April. 1999

Month/Day/Year

17. If applicable: anticipated date that identifiers will be removed from completed survey instruments and/or audio or visual tapes will be erased:

\section{Month/Day/Year}

18. Signature of Departmental Executive

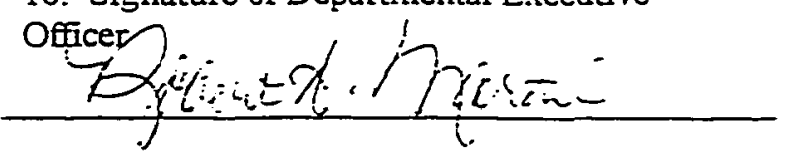

Date

Department or Administrative Unit

19. Decision of the University Human Subjects Review Committee: Q Project approved $\square$ Project not approved

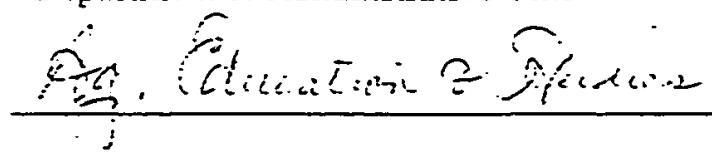

$\square$ No action required

Name of Human Subjects in Research Committee Chair Patricia M. Keith

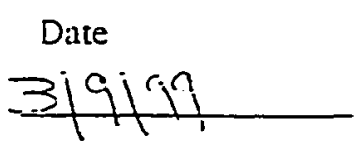

Signature of Commintee Chair 
APPENDIX B.

STUDENT QUESTIONNAIRE 


\section{NORTHWEST IOWA RURAL ASPIRATION STUDY}

Thank you for participating in this study of high school seniors in Northwest Iowa. Your answers are important and will be used to identify specific characteristics of students in this region. Please attempt to answer every question, but you may skip any question you do not wish to answer. Your answers as an individual are confidential. PLEASE USE NO. 2 PENCIL BY FULLING IN THE CIRCLES ON THE ANSWER SHEET LIKE THIS: $O$ DO NOT CROSS $(X)$ OR CHECK $(\Omega)$ THE CIRCLES.

I. Put your name of your HIGH SCHOOL in the "NAME" box of the answer sheet and blacken the appropriate circles.

II. Indicate your gender in the "SEX" box small box to the right of the "NAME" box on your answer sheet.

III. In the SPECLAL CODES box on your answer sheet under "K", fill in the blank and darken the appropriate circle to answer the following question: What do you consider yourself to be in the U.S.? (Select best answer)
0) White Caucasian
3) American Indian
6) Other
1) Hispanic/Latino
4) Oriental or Asian American
2) Black or African American
5) I am an exchange student

IV. In the SPECIAL CODES box on your answer sheet under the " $L$ ", fill in the blank and darken the appropriate circle to answer the following question. My present grade point average (GPA) is:
0) $3.5-4.0$
1) $3.0-3.49$
2) $2.5-2.99$
3) $2.0-2.49$
4) 1.99 or lower
5) Don't know

Please answer the following questions on your answer sheet by filling in the appropriate circle on the answer sheet provided.

1. I live: (select the best answer)
a) in a house in town
b) in an aparment in town
c) on an acreage (house or farm site in the country)
d) on a small farm (approx. 100-400 acres)
e) on a farm of more than 400 acres

2. I live miles from my school (select best answer).

a. $0-5$ miles

b. $6-10$ miles

c. $11-15$ miles

d. $16-20$ miles

e. 21 or more miles

3. My mother (select the most correct answer):

1) did not graduate from high school

2) graduated from high school or earned her GED

3) graduated from a trade, business, technical school or community college

4) graduated from a 4-yr. college or university

5) has a Masters, Ph.D. or other degree beyond a 4-yr. college degree 
4. My father (select the mosi correct answer):
a. did not graduate from high school
b. graduated from high school or earned his GED
c. graduated from a trade, business, technical school or community college
d. graduated from a 4-yr. college or university
e. has a Masters, Ph.D. or other degree beyond a 4-yr. college degree

5. My mother attended:
a. this high school
b. a high school within 25 miles of this high school
c. a high school $26-50$ miles away
d. high school $51-100$ miles away
e. a high school over 100 miles away

6. My father attended:
a. this high school
b. a high school within 25 miles of this high school
c. a high school 26-50 miles away
d. a high school $51-100$ miles away
e. a high school over 100 miles away

7. What is the present status of your parent or parents in the place where you live? (Select best answer)
a. Married, never divorced
b. Married, but one or both parents were previously divorced.
c. Single parent: either divorced, never married, widowed, or separated
d. Parents deceased, living with a guardian, grandparents, or relatives
e. None of the above

8. I have brothers and sisters.
a) 0
b) 1
c) 2
d) 3
e) 4 or more

9. What best describes your position as a child within the family? (Select best answer)
a. I am an only child
b. I am the oldest
c. I am between the oldest and youngest
d. I am the youngest child

10. How would you describe the financial condition of your parents or guardians? (Select the best answer)
a. they are disadvantaged financially and struggie from month to month to make ends meet
b. they have a below average income compared to other families in the community
c. they have an average income compared to other families in the community
d. they have an above average income compared to other families in the community
e. they live quite comfortably and have many economic advantages that others do not have

11. My activity in a church or synagogue is that: (select best answer)

a. I do not attend or participate in religious activities

b. I attend services or participate in activities weekly

c. I attend services or participate in activities approximately once or twice a month (12-24 time/year)

d. I try to attend a service or participate in activities about one to eleven times per year

e. I only attend weddings, funerals, and anniversaries at religious facilities 
12. The community where I now live :
a. is a great place to live
b. is a good place to live
c. is an average place to live
d. is not the most desirable place to live
e. is a very undesirable place to live

13. Do you plan to enter the military after you leave high school?
a. Definitely will enter the military
b. Likely will enter the military
c. Not sure
d. Not likely to enter the military
e. Definitely will not enter the military

14. Do you plan to attend a college, university, or trade school after high school?
a. Definitely will attend
b. Likely will attend
c. Not sure
d. Not likely to attend
e. Definitely will not attend

15. What additional education do you plan after high school? (Select best answer)
a. I do not plan any additional education after high school.
b. Attend a two-year community college
c. Attend a two-year community college and then a four-year college or university
d. Attend a four-year college or university
e. Attend a trade, technical, or business school

16. Where do you think that you will be living at age 30 ? (Select best answer)
a. In the local area where I now live
b. Within 75 miles of where I now live
c. Between 75 and 200 miles away
d. More than 200 miles away
e. I have no idea

17. How many hours per week do you work for pay?
a.) 0 hours
b) $0-10$
c) $11-20$
d) more than 20 hours/week

18. What is the major reason that you work for pay? (Select the best answer)
a. I do not work for pay
b. My parent(s) or guardian(s) encourage me to work
c. I need the money for food, clothing, and other necessities
d. I need the money to pay for my transportation expenses (car, gas, etc)
e. I need money for future plans (college, business, car, etc.)

19. My high school education has been:
a. excellent in academic quality
b. good in academic quality
c. fair in academic quality
d. poor in academic quality
e. I do not know 
20. How many years have you participated in FFA (Future Farmers of America)?
a) 0
b) 1
c) 2
d) 3
e) 4 or more

Please answer the following questions with yes (a) or no (b). MARK THE OVAL ON ANSWER SHEET.

21. I have participated in $4-\mathrm{H}$

22. I am a son or daughter of a farmer

23. I have taken one or more agriculture courses in school

24. One or more of my sets of grandparents were farmers

25. I took one or more of the following: technical drawing or a shop class

26. I took chemistry or physics or both

27. I took one or more of the following: calculus, geometry, trigonometry

28. I participated in either in a class play or academic team competition

29. I have been on a sports team in school, church, or town

30. I have been an officer for a school, church, or community group

31. I have participated in a choir, band, or a musical group in school

32. I took one or more foreign language classes

33. I drive to school (or car pool) the majority of the time

34. I have gone on a school sponsored trip to a city more than 100 miles away

Yes
0
0
0
0
0
0
0
0
0
0
0
0
0
0

No (b)

The next questions are intended to identify barriers that may keep you from ACHIEVING YOUR FUTURE GOALS. (MARK OVAL ON ANSWER SHEET)

35. Lack of money for education

36. No place to get further education near home

37. Lack of transportation

38. Did not take the right courses in high school

39. Parents-family disapprove of my future goals

40. Family or home responsibilities

41. I do not think that I will be successful

42. Did not get high enough grades

43. Don't know about career opportunities

44. Do not have the necessary skills

45. Lack of jobs/bad economy in local area

46. Job I want doesn't pay enough

47. Sexual discrimination

48. Not wanting to work hard

49. Living in a rural place

50. Racism

51. I am not good at school work

52. Can't get admitted into a school of my choice

$\begin{array}{ccc}\begin{array}{l}\text { Large } \\ \text { barrier (a) }\end{array} & \begin{array}{c}\text { Somewhat of } \\ \text { a barrier (b) }\end{array} & \begin{array}{c}\text { Not a } \\ \text { Barrier (c) }\end{array} \\ 0 & 0 & 0 \\ 0 & 0 & 0 \\ 0 & 0 & 0 \\ 0 & 0 & 0 \\ 0 & 0 & 0 \\ 0 & 0 & 0 \\ 0 & 0 & 0 \\ 0 & 0 & 0 \\ 0 & 0 & 0 \\ 0 & 0 & 0 \\ 0 & 0 & 0 \\ 0 & 0 & 0 \\ 0 & 0 & 0 \\ 0 & 0 & 0 \\ 0 & 0 & 0 \\ 0 & 0 & 0 \\ 0 & 0 & 0 \\ 0 & 0 & 0\end{array}$

The next questions are intended to identify factors that could IMPROVE YOUR OPPORTUNITIES. (MARK OVAL ON ANSWER SHEET)

53. Offer more college courses in high school

54. Offer more job training courses in high school

55. Have college courses available over the Internet

56. Have better paying jobs in my community

$\begin{array}{lll}\text { Very } & \text { Somewhat } & \text { Not } \\ \text { Important (a) } & \text { Important (b) } & \text { Important (c) } \\ 0 & 0 & 0 \\ 0 & 0 & 0 \\ 0 & 0 & 0 \\ 0 & 0 & 0\end{array}$


57. Shared teachers and courses with other schools

58. If I lived in a city

59. Have more financial help to obtain more schooling

$\begin{array}{lll}0 & 0 & 0 \\ 0 & 0 & 0 \\ 0 & 0 & 0\end{array}$

How important are the following TO YOUR FUTURE? (MARK OVAL ON ANSWER SHEET)

$\begin{array}{ccc}\text { Very } & \text { Somewhat } & \text { Not } \\ \text { Important (a) } & \text { Important (b) } & \text { Important (c) } \\ 0 & 0 & 0 \\ 0 & 0 & 0 \\ 0 & 0 & 0 \\ 0 & 0 & 0 \\ 0 & 0 & 0 \\ 0 & 0 & 0 \\ 0 & 0 & 0 \\ 0 & 0 & 0 \\ 0 & 0 & 0 \\ 0 & 0 & 0 \\ 0 & 0 & 0 \\ 0 & 0 & 0 \\ 0 & 0 & 0 \\ 0 & 0 & 0 \\ 0 & 0 & 0 \\ 0 & 0 & 0 \\ 0 & 0 & 0 \\ 0 & 0 & 0 \\ 0 & 0 & 0 \\ 0 & 0 & 0 \\ 0 & 0 & 0 \\ 0 & 0 & 0 \\ 0 & 0 & 0 \\ 0 & 0 & 0\end{array}$

60. Live near a church of my faith

61. Find the right person to marry

62. Getring a two-year college degree

63. Getting at least a four-year college degree

64. Live near where I now live

65. Live in a big city like Chicago or New York

66. Live in a medium-sized city like Sioux Falls or Sioux City

67. Live in a small town

68. Live out in the country on a farm or acreage

69. Having a spiritually fulfilling life

70. Provide volunteer service in my community

71. Be able to support myself comfortably

72. Live close to parents and relatives

73. Trying to do the right thing

74. Travel to places outside the U.S.

75. Working to correct social and economic problems

76. Having lots of money

77. Raising a family

78. Staying healthy

79. Voting in elections

80. Being successful in my job or career

81. Help improve and care for the environment

82. Enjoying my spare time

83. Pursue an agriculturally related career

For each statement, please indicate if you Strongly Agree, Agree, Don't Know, Disagree, or Strongly Disagree.

84. I am optimistic about the furure

85. My parents are positive role models for me

86. I make sacrifices today to benefit my future

87. Teachers respect my thoughts

88. My parents think going to college is important for me

89. What I learn in school will benefit my future

90. Teachers make learning exciting

91. My courses help me to understand my everyday life

92. I put forth the necessary effort to reach a goal

93. Anyone can succeed if they work hard enough

94. I am usually bored in school

95. I feel safe in school

96. My parents like my school

97. I am a positive role model for other students

98. Students show respect for teachers

$\begin{array}{ccccc}\begin{array}{c}\text { Strongly } \\ \text { agree }\end{array} & \text { Agree } & \begin{array}{c}\text { Don't } \\ \text { Know }\end{array} & \begin{array}{c}\text { Disagree } \\ 0\end{array} & \begin{array}{c}\text { Strongly } \\ \text { Disagree }\end{array} \\ 0 & 0 & 0 & 0 & 0 \\ 0 & 0 & 0 & 0 & 0 \\ 0 & 0 & 0 & 0 & 0 \\ 0 & 0 & 0 & 0 & 0 \\ 0 & 0 & 0 & 0 & 0 \\ 0 & 0 & 0 & 0 & 0 \\ 0 & 0 & 0 & 0 & 0 \\ 0 & 0 & 0 & 0 & 0 \\ 0 & 0 & 0 & 0 & 0 \\ 0 & 0 & 0 & 0 & 0 \\ 0 & 0 & 0 & 0 & 0 \\ 0 & 0 & 0 & 0 & 0 \\ 0 & 0 & 0 & 0 & 0 \\ 0 & 0 & 0 & 0 & 0\end{array}$


99. I have a teacher who is a positive role model for me 100. I am dependable

$\begin{array}{lllll}0 & 0 & 0 & 0 & 0 \\ 0 & 0 & 0 & 0 & 0\end{array}$

GO TO THE WHITE PAGE ATTACHED TO THE COMPUTER SHEET AND WRITE IN YOUR ANSWERS TO THE FINAL QUESTIONS ON THAT SHEET. 


\section{NORTHWEST IOWA RURAL ASPIRATION STUDY}

\section{THE REMAINING RESPONSES ARE TO BE WRITTEN ON THIS PAGE. YOU ARE FINISHED WITH YOUR FILL-IN-THE-CIRCLE ANSWER SHEET. ANSWER THE REMAINING QUESTIONS BY WRITING THE ANSWERS IN THE BLANKS ON THIS PAGE.}

1. What is the PRMMARY occupation of your father? (If not living or not applicable, leave blank. Be as specific as possible)

2. If your father has a second job, what job is that? (If none, leave blank)

3. What is the PRIMARY occupation of your mother? (If not living or not applicable, leave blank. Be as specific as possible)

4. If your mother has a second job, what is it? (If none, leave blank)

5. If you attend a school after high school, what PROGRAM OF STUDY will you enroll in? (If you do not plan to atrend school, leave the question blank)

6. What church do you regularly attend? (Leave blank if you do not attend)

7. What job do you WANT TO HAVE when you are 30 years old? (Even if you are not at all sure, write your best guess. Be as specific as possible)

8. What job will you PROBABLY HAVE when you are 30 years old? (Even if you are not at all sure, write your best guess. Be as specific as possible)

Thank you very much for your cooperation in completing this survey. 
APPENDIX C.

CORRESPONDENCE WITH HIGH SCHOOLS 
January 20, 1999

To: $\quad$ High School Principals in AEA 4 c/o Marjorie Wagner

From: Duane Bajema

Re: $\quad$ Research study

Allow me to introduce myself. I have worked in Northwest Iowa as a faculty member at Dordt College for the past twenty-one years. I am presently on leave at Iowa State University in the Agricultural Education and Studies Department pursuing my Ph.D.

I have an interest in rural schools and have developed a research proposal for my dissertation that examines the educational and vocational aspirations of youth in rural schools. Previous research has raised some unanswered questions. None of the previous work has been done in a focused rural area. I felt that Northwest Iowa would be an excellent place to further examine the issue since it has a strong agricultural base, all of the schools are considered rural schools, and I have received initial encouragement and indications of support from Dr. Gary Hayden of AEA 4 as well as some of the school administrators in the area. I feel that the information will be valuable to each school in their assessment process.

I am developing a survey instrument that would examine the educational and vocational aspirations of high school seniors. The instrument should take between 10-20 minutes to complete.

I wanted to visit with each superintendent and principal personally to inform you of the potential study, but I have not been able to do so yet. I do not know if I will be able to visit personally with each of you, but for the present, I want to share my intentions with you via this letter. I have the following requests.

First, I need permission to conduct the research in your school. Some of you have already given your permission and have expressed enthusiasm to participate. Those of you with whom I have spoken feit that the information would be helpful to each school as you strive to improve. I will be contacting each of you to learn if you are willing to cooperate. I must emphasize that school participation is voluntary.

Secondly, if you are willing to cooperate as a school, I will be asking for the cooperation and assistance of the principals and superintendents. Dr. Gary Hayden has given me his initial support by allowing me to disseminate the research materials via the AEA 4 mail van.

I need the help of the principal to determine how the surveys will be administered to all of the seniors in your respective schools. Your ideas and suggestions will be welcomed, and I will ask for your input when I contact you. I realize that I am asking for a substantial amount of help from the principals, but without your cooperation, my ability to conduct the study would be questionable. I will try to be as efficient and respectful of your time as possible when I send instructions, envelopes, and survey instruments. 
Page 2

AEA 4 Principals

January 20, 1999

The final details of the survey are still in development, and I know that I have not given you all of the details. I will visit or call you later to learn if you are willing, as a school, to participate in the study. I will have more details available for you then. If you will be cooperating, I will ask you how best to cooperate with you in the conducting of the research in your school.

My goal is to distribute the survey in February for administration in the cooperating schools of AEA 4. My understanding is that you will be meeting on Thursday, January 21, and that this letter will be distributed at that time for your information and discussion. I will call Marjorie after your meeting to learn if there were questions so that when I contact you, I will be prepared to provide you with the necessary information.

I may start calling you the latter part of the following week to learn of your reactions, and I will try to answer any questions that you may have at that time.

Respectfully,

Duane Bajema

cc: Dr. Gary Hayden 
March 23, 1999

To: $\quad$ Principals of high schools in AEA 4

From: Duane Bajema, Iowa State University

Re: Implementation of survey

The final details for implementing the study of all of the high school seniors in AEA 4 have been completed. The materials for the study accompany this letter.

The packet of materials contains a consent form that needs the principal's signature. An explanation is attached to the consent form. PLEASE SIGN THE FORM AND RETURN THE FORM when you return the study materials.

Please distribute the study instrument and the two-page answer sheet to the students at an appropriate time. The students should fill out the answer sheets with \#2 pencil.

Please give the following instructions to the students:

1. Place your answers on the two-page answer sheets. Do NOT SEPARATE the two pages. Do not write on the study instrument.

2. On the NAME section of the answer sheet, enter the initials for your high school and darken the appropriate circles

3. Follow the instructions on the study questionnaire.

4. Please remember to answer the questions on the second sheet attached to the computer sheet. Please write your answers legibly.

5. When finished, hand in the 5-page "Aspiration Study" on one pile and the 2-page answer sheet on another pile.

Please return the 1) consent form, 2) Aspiration Study questionnaire, 3) and the answer sheets to AEA 4 via their mail van as soon as possible.

I want to thank you for your cooperation in the study of AEA 4. Your participation, help, and encouragement have been very important to me. I will share the results with you in the future.

If you have any questions, I can be contacted at 515-294-4349 at my office at Iowa State University or at 515-572-4233 at my apartment. 
Date:

To: $\quad$ Cooperating Principals of Research Study

From: Duane Bajema

Re: Administration of the survey

Thank you to each of you for cooperating in the study of the high school seniors in AEA 4. The survey instruments and one computer bubble answer sheet for each student are enclosed. Please arrange to have the survey implemented.

Please give the students the following information and instructions. Please have the students use a \#2 pencil to complete the computer bubble sheet and give them the following instructions:

"A study is being conducted by Iowa State University of all the high schools seniors of each school in AEA 4 that will examine your educational and occupational aspirations. The information will be used to assist in the identification of potential barriers that may exist in the schools of Northwest Iowa. There should be no discomforts or risks to you in completing the survey.

The information that you will provide is very important. The results will aid in the improvement of high school education in AEA 4. Please answer the questions carefully and to the best of your ability. If you have any questions or if for some reason you are unable or unwilling to fill out the survey, please inform your principal. Your participation is voluntary and you may withdraw from the procedure at any time.

Your principal will be given summary written information about your school which may be used to improve the school. The information that you provide will be confidential. Your name is not requested.

Fill in the name of your high school in the "NAME" portion of your computer answer sheet and darken the appropriate circles. Indicate your gender by darkening the correct circle in the "SEX" box just to the right of the "NAME" box. Then please answer the questions of the survey by darkening your answer on the computer bubble sheet. Return the survey and the answer sheets when you are finished.

Your cooperation is much appreciated. Thank you for participating in the study." 
March 5, 1999

To: $\quad$ Principals of High Schools in AEA 4

From: Duane Bajema, Ph.D. candidate

Deparment of Agricultural Education

Iowa State University

Ames, Iowa 50011

(515) 294-4349

Re: $\quad$ Study of high school seniors

I am asking for your permission and cooperation to conduct a study of the seniors in your respective high schools in Area Education Agency 4 (AEA 4). The purpose of the study is to examine the occupational and educational aspirations of rural high school seniors and to determine what barriers may inhibit their aspirations. The information obtained will be used to complete a Ph.D. program.

I am asking you as a principal, or have someone you appoint within your school, administer a survey to your high school seniors. Your time will be required to administer the survey and subsequently return the survey and the computer answer sheet to me. I will send you the instruments, answer sheets, specific instructions, and the envelope to return the instruments.

The seniors will be asked to complete a survey instrument. The student will identify the school they attend, but they will not provide their names so that student confidentiality is maintained. The time required to complete the survey is approximately fifteen (15) minutes. There should be no discomfort or risk associated with the completion of the survey. Their participation is voluntary.

I agree to share written results of the study with each school. Individual schools may be referenced to overall AEA 4 results, but individual schools will not be compared. The results should be helpful to each school as you carry out your school assessment activity.

Please feel free to contact me with any questions. Your participation is encouraged but is voluntary. You are free to withdraw or discontinue your participation at any time during the study.

If you agree to participate in the study, please sign below and return this letter to me. Please keep a copy of this letter for your files if you desire. If you cannot participate, return this letter UNSIGNED with your school name.

I agree to cooperate with the study conducted by Duane Bajema of Iowa State University of the occupational and educational aspirations of the seniors in my high school. I understand that I may withdraw or discontinue my participation at any time. 
April 20, 1999

To: $\quad$ Principals of High Schools in AEA 4

From: Duane Bajema, Ph.D. candidate

Department of Agricultural Education

Iowa State University

Ames, Iowa 50011

(515) 294-4349

Re: Study of high school seniors

I want to thank you for implementing the Northwest Iowa Aspiration Survey in your high school. I have received most of the finished surveys from AEA 4. I am still waiting for a couple of schools to administer the surveys, and when I receive them, I should be ready to tabulate the information and conduct the analysis. The survey materials made it back to AEA 4 in good shape.

I want to compliment your students. My colleagues at Iowa State frequently share information they receive back on their research instruments, and many times, high school students do not take their task very seriously, and it shows on the comments made and in the manner that they fill out the forms. I was very impressed with the quality of the returns that I have received thus far from the schools in AEA 4. The forms were filled out reasonably well, and where written comments were requested, the comments were generally of good quality and of a serious nature.

I felt somewhat guilty asking you to help me because of the imposition upon you, your students, and the educational program of your school, but in order to get the job done, I had to persist. Your cooperation was gratifying.

It will take me some time to tabulate and analyze the results, but upon completion of the study, I will contact you to make arrangements to share the results of your school with you if you have the interest. Please patient with me as I continue my work.

Again, thank you for your cooperation.

Sincerely,

Duane Bajema

cc: Dr. Gary Hayden 
APPENDIX D.

JOB CLASSIFICATION 
[Accessibility Information]

\section{Standard Occupational Classification (BSS}

\section{SOC Major Groups}

Each occupation in the SOC is placed within one of these 23 major groups:

11-0000 Management Occupations

13-0000 Business and Financial Operations Occupations

15-0000 Computer and Mathematical Occupations

17-0000 Architecture and Engineering Occupations

19-0000 Life, Physical. and Social Science Occupations

21-0000 Community and Social Services Occupations

23-0000 Legal Occupations

25-0000 Education, Training, and Library Occupations

27-0000 Arts. Design. Entertainment. Sports. and Media Occupations

29-0000 Healthcare Practitioners and Technical Occupations

31-0000 Healthcare Support Occupations

33-0000 Protective Service Occupations

35-0000 Food Preparation and Serving Related Occupations

37-0000 Building and Grounds Cleaning and Maintenance Occupations

39-0000 Personal Care and Service Occupations

41-0000 Sales and Related Occupations

43-0000 Office and Administrative Support Occupations

45-0000 Farming, Fishing, and Forestry Occupations

47-0000 Construction and Extraction Occupations

49-0000 Installation, Maintenance, and Repair Occupations 
51-0000 Production Occupations

53-0000 Transportation and Material Moving Occupations

55-0000 Military Specific Occupations

Numerical Index of Detailed Occupations

SOC User Guide

SOC Home Page

BIS

Bureau of Labor Statistics

socrevision@bls.gov

Last modified: June 1, 1999

URL: http://stats.bls.gov/soc/soc_majo.htm 
51-0000 Production Occupations

53-0000 Transportation and Material Moving Occupations

55-0000 Military Specific Occupations

Numerical Index of Detailed Occupations

$\underline{\text { SOC User Guide }}$
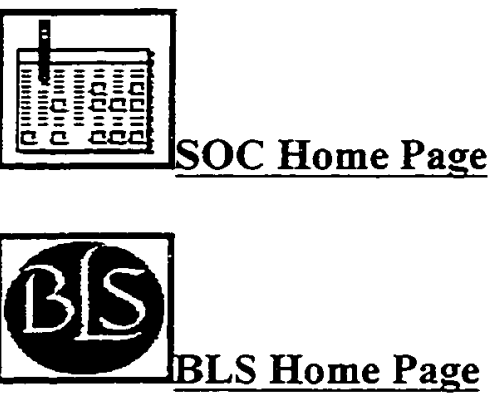

Bureau of Labor Statistics socrevision@bls.gov

Last modified: June 1, 1999

URL: http://stats.bls.gov/soc/soc_majo.htm 
APPENDIX E.

\section{RURAL DEFINITIONS}


Bureau of the Census. The Census Bureau delineates urbanized areas (UA's) to provide a better separation of urban and rural territory, population, and housing in the vicinity of large places. A UA comprises one or more places ("central place") and the adjacent densely settled surrounding territory ("urban fringe") that together have a minimum of 50,000 persons. The urban fringe generally consists of contiguous territory having a density of at least 1,000 persons per square mile. The urban fringe also includes outlying territory of such density if it was connected to the core of the contiguous area by road and is within 1 1/2 road miles of that core, or within 5 road miles of the core but separated by water or other undevelopable territory. Other territory with a population density of fewer than 1,000 people per square mile is included in the urban fringe if it eliminates an enclave or closes an indentation in the boundary of the urbanized area. The population density is determined by (1) outside of a place, one or more contiguous census blocks with a population density of at least 1,000 persons per square mile or (2) inclusion of a place containing census blocks that have at least 50 percent of the population of the place and a density of at least 1,000 persons per square mile.

Source: http://www.census.gov/population/censusdata/urdef.txt

Office of Management and Budget. The OMB defines those areas as Metro (Metropolitan Statistical Area-MSA)that include at least one city with 50,000 or more residents, or an urbanized area (as defined by the Bureau of the Census) with at least 50,000 residents and a total MSA population of 100,000 or more. The OMB standards dictate that each MSA must include the county in which the central city is located (central county) and additional contiguous counties, if they are economically and socially integrated with the central county. Any county not included in an MSA is considered nonmetro.

Source: http://www.econ.ag.gove/briefing/rural/data/code93.txt

Economic Research Service. The ERS uses rural-urban continuum codes to distinguish among metro, nonmetro (adjacent to metro areas), and nonmetro (not adjacent to metro areas) counties. The rural-urban continuum code reads as follows:

0 Central counties of metro areas of 1 million population or more

1 Fringe counties of metro areas of 1 million population or more

2 Counties in metro areas of 250,000 to 1 million population

3 Counties in metro areas of fewer than 250,000 population

4 Urban population of 20,000 or more, adjacent to a metro area

5 Urban population of 20,000 or more, not adjacent to a metro area

6 Urban population of 2,500 to 19,999, adjacent to a metro area

7 Urban population of 2,500 to 19,999, not adjacent to a metro area

8 Completely rural or fewer than 2,500 urban population, adjacent to a metro area

9 Completely nural or fewer than 2,500 urban population, not adjacent to a metro area

Codes 0 through 3 comprise metro counties; Codes $4,6, \& 8$ comprise nonmetro counties adjacent to metro areas; and codes $5,7, \& 9$ comprise nonmetro counties, not adjacent to metro areas. 
Johnson Code. The Johnson code categorizes community types into the following seven categories:

1 Large City: A central city of a CMSA or MSA, with the city having a population greater than or equal to 250,000

2 Mid-size City: A central city or a CMSA or MSA, with the city having a population less than 250,000

3 Urban Fringe of a Large City: Any incorporated place, CDP, or non-place territory within a CMSA or MSA of a Large City, and defined as urban by the Census Bureau

4 Urban Fringe of a Mid-size City: Any incorporated place, CDP, or non-place territory within a CMSA or MSA of a Mid-size City, and defined as urban by the Census Bureau

5 Large Town: An incorporated place of CDP with a population greater than or equal to 25,000 and located outside a CMSA or MSA

6 Small Town: An incorporated place or CDP with a population less than 25,000 or equal to 2,500 and located outside a CMSA or MSA

7 Rural: Any incorporated place, CDP, or non-place territory designated as rural by the Census Bureau

Source: http://nces.ed.gov/pubs99/1999316.pdf 
APPENDIX F.

PROGRAM CODES 
Table 115. Initial program of study codes

\begin{tabular}{|c|c|c|c|c|}
\hline Valid & Frequency & Percent & $\begin{array}{c}\text { Valid } \\
\text { percent }\end{array}$ & $\begin{array}{l}\text { Cumulative } \\
\text { percent }\end{array}$ \\
\hline Business/Marketing & 96 & 11.3 & 12.9 & 12.9 \\
\hline Aviation & 4 & 0.5 & 0.5 & 13.4 \\
\hline Accounting & 14 & 1.6 & 1.9 & 15.3 \\
\hline General & 22 & 2.6 & 2.9 & 18.2 \\
\hline \multicolumn{5}{|l|}{ Computers and computer } \\
\hline related programs & 34 & 4.0 & 4.6 & 22.8 \\
\hline Mathematics & 5 & 0.6 & 0.7 & 23.4 \\
\hline Engineering-All types & 30 & 3.5 & 4.0 & 27.4 \\
\hline Design including Graphic Design & 15 & 1.8 & 2.0 & 29.5 \\
\hline Political Science & 6 & 0.7 & 0.8 & 30.3 \\
\hline Foreign Language & 4 & 0.5 & 0.5 & 30.8 \\
\hline Pre-Law & 9 & 1.1 & 1.2 & 32.0 \\
\hline Education-All types & 63 & 7.4 & 8.4 & 40.4 \\
\hline Public Relations & 6 & 0.7 & 0.8 & 41.2 \\
\hline Arts & 13 & 1.5 & 1.7 & 43.0 \\
\hline Nursing & 26 & 3.0 & 3.5 & 46.5 \\
\hline Law Enforcement & 18 & 2.1 & 2.4 & 48.9 \\
\hline Construction, Carpentry & 11 & 1.3 & 1.5 & 50.3 \\
\hline Turf Management & 3 & 0.4 & 0.4 & 50.7 \\
\hline Horticulture & 6 & 0.7 & 0.8 & 51.5 \\
\hline Cosmetology & 10 & 1.2 & 1.3 & 52.9 \\
\hline Mechanic-Diesel, car & 19 & 2.2 & 2.5 & 55.4 \\
\hline Electrician & 14 & 1.6 & 1.9 & 57.3 \\
\hline Fashion Design & 1 & 0.1 & 0.1 & 57.4 \\
\hline Heavy Equipment Operation & 2 & 0.2 & 0.3 & 57.7 \\
\hline Child Care & 8 & 0.9 & 1.1 & 58.8 \\
\hline Auto Body & 6 & 0.7 & 0.8 & 59.6 \\
\hline Secretarial Training & 9 & 1.1 & 1.2 & 60.8 \\
\hline Two-year Associate Program & 16 & 1.9 & 2.1 & 62.9 \\
\hline Technical School & 9 & 1.1 & 1.2 & 64.1 \\
\hline Golf Course Management & 1 & 0.1 & 0.1 & 64.3 \\
\hline Military & 6 & 0.7 & 0.8 & 65.1 \\
\hline Student & 1 & 0.1 & 0.1 & 65.2 \\
\hline Undecided & 37 & 4.3 & 5.0 & 70.1 \\
\hline Architecture & 2 & 0.2 & 0.3 & 70.4 \\
\hline Psychology & 21 & 2.5 & 2.8 & 73.2 \\
\hline Biology & 17 & 2.0 & 2.3 & 75.5 \\
\hline Wildlife Management & 2 & 0.2 & 0.3 & 75.8 \\
\hline Social Worker & 9 & 1.1 & 1.2 & 77.0 \\
\hline Environmental Studies & 5 & 0.6 & 0.7 & 77.6 \\
\hline
\end{tabular}


Table 115. Continued

\begin{tabular}{|c|c|c|c|c|}
\hline Valid & Frequency & Percent & $\begin{array}{c}\text { Valid } \\
\text { percent }\end{array}$ & $\begin{array}{c}\text { Cumulative } \\
\text { percent }\end{array}$ \\
\hline Physics/Chemistry & 6 & 0.7 & 0.8 & 78.4 \\
\hline English & 5 & 0.6 & 0.7 & 79.1 \\
\hline Theology/Pre-Sem & 6 & 0.7 & 0.8 & 79.9 \\
\hline Social Worker & 9 & 1.1 & 1.2 & 81.1 \\
\hline Communications & 19 & 2.2 & 2.5 & 83.7 \\
\hline Journalism & 2 & 0.2 & 0.3 & 83.9 \\
\hline Music & 5 & 0.6 & 0.7 & 84.6 \\
\hline Physical Therapy & 9 & 1.1 & 1.2 & 85.8 \\
\hline Pre-Med, Chiropractic, Pre-Health & 31 & 3.6 & 4.1 & 90.0 \\
\hline Health related programs & 22 & 2.6 & 2.9 & 92.9 \\
\hline Athletic Trainer & 4 & 0.5 & 0.5 & 93.4 \\
\hline Biomedical Equipment & 1 & 0.1 & 0.1 & 93.6 \\
\hline Physical Education & 3 & 0.4 & 0.4 & 94.0 \\
\hline Hotel Management & 1 & 0.1 & 0.1 & 94.1 \\
\hline Message Therapy & 5 & 0.6 & 0.7 & 94.8 \\
\hline Agriculture, Ag Business & 20 & 2.3 & 2.7 & 97.5 \\
\hline Dairy Science & 2 & 0.2 & 0.3 & 97.7 \\
\hline Animal Ecology & 4 & 0.5 & 0.5 & 98.3 \\
\hline Animal Science & 5 & 0.6 & 0.7 & 98.9 \\
\hline Pre-Vet & 4 & 0.5 & 0.5 & 99.5 \\
\hline Agronomy & 2 & 0.2 & 0.3 & 99.7 \\
\hline Equine & 1 & 0.1 & 0.1 & 99.9 \\
\hline Ag Education & 1 & 0.1 & 0.1 & 100.0 \\
\hline Total & 747 & 87.6 & 100.0 & \\
\hline Missing & 106 & 12.4 & & \\
\hline Total & 853 & 100.0 & & \\
\hline
\end{tabular}


Table 116. Consolidations of program of study $(N=747)$

\section{Major grouping}

Initial category

Total

Agriculnure

Ag/Ag Business

20

Ag Education

1

Agronomy

Animal Ecology

2

Animal Science

4

Dairy Science

5

Equine

Horticulture

Pre-Vet

48

Turf Management

3

Arts, Design, Graphic Design

Arts, Design, Graphic Design

15

Arts

13

Music

Aviation

Biology

Biology

17

Environmental Studies

Business/Marketing

Accounting

14

Business/Marketing

Hotel Management

Public Relations

117

Computer related

Education

Engineering/Architecture/

Mathematics

Architecture

2

Engineering

30

Mathematics

37

English/Communications/

Journalism/Pre-Sem

Communication

19

English

5

Journalism

Pre-Sem

2

6

32 
Table 116. Continued

Major grouping

Initial category

$\underline{f}$

Total

General

Health-Pre-Med, Nursing, Chiropractor

Pre-Med and Chiropractor Nursing

Health Support/Physical Therapy/Athletic Trainer

Athletic Trainer Biomedical Equipment 1

Health related 22

Physical Education 3

Physical Therapy 9

Law Enforcement

Mechanic/Auto Body/Diesel

Auto Body

Diesel

19

Heavy Equipment Operation

Military

Personal Care/Cosmetology/ Child Care/Massage

Cosmetology

10

Child Care

Fashion Design

Massage Therapy

Physics/Chemistry

Political Science/Pre-Law/

Foreign Language

Foreign Language

Political Science

Pre-Law

Psychology/Social Work

Psychology

Social Work

Secretarial 
Table 116. Continued

Major grouping

Technical School

Technical

Initial category
Golf Course Management

$\underline{f}$

Total

Undecided
1

16

9 


\section{REFERENCES}

Agresti, Louis J., \& Agresti, Marjorie H. (1997). Statistical methods for the social sciences (3 ed.). Upper Saddle River, NJ: Prentice Hall.

Alexander, K. L., Eckland, B. K., \& Griffin, L. J. (1975). The Wisconsin model of socioeconomic achievement: A replication. American Joumal of Sociology, 81, 324-342.

Alvord, Dave. (June 1, 1999). Personal communication from Iowa Department of Education.

Ary, D., Jacobs, L. C., \& Razavieh, A. (1990). Introduction to research in education (4 ${ }^{\text {th }}$ ed.). Fort Worth: Harcourt Brace College Publishers.

Blau, P. M., \& Duncan, O. D. (1967). The American occupational structure. New York: John Wiley \& Sons.

Bloom, B. S. (Ed.), Englehart, M. D., Furst, E. J., Hill, W. H., \& Krathwohl, D. R. (1956). Taxonomy of educational objectives. The classification of educational goals, Handbook I: Cognitive domain. New York: Longmans, Green Co.

Breen, D. T., \& Quaglia, R. (1991). Raising student aspirations: The need to share a vision. The School Counselor, 38, 221-228.

Bureau of Labor Statistics. (1998). URL: http://stats.bls.gov/soc/soc_deta.htm.

Carlson, J. E., Lassey, M. L., \& Lassey, W. R. (1981). Rural society and environmental America. New York: McGraw-Hill.

Cobb, R. A., McIntire, W. G., \& Pratt, P. A. (1989). Vocational and educational aspirations of high school students; A problem for rural America. Research in Rural Education, 6(2), 11-16.

Collier, G. (1994). Social origins of mental ability. New York: John Wiley and Sons.

Comenius, J. A. (1910). Didacta magna. English. Translated by Keatinge, M. W. London: A. and C. Black.

Cox, H. G. (1996). The secular city: Secularization and urbanization in a theological perspective. New York: Macmillan.

Curry, E. W., \& Picou, J. S. (1971). Rural youth and anticipatory occupational goal deflection. Journal of Vocational Behaviour, I(4), 317-330.

Davis, J. A. (1971). Elementary survey analysis. Englewood, NJ: Prentice-Hall. 
De Antonio, E. (1971). Coming of age in the industrialist state: The ideology and implementation of rural school reform 1893-1925. Doctoral dissertation, Cornell University, NY.

De Board, L. W., Griffin, L. J., \& Clark, M. (1977). Race and sex influences in the schooling processes of rural and small town youth. Sociology of Education, 50,(2), 85-102.

De Jong, J. (1984). The Calvinist ethic in two generations: A study of personality style among Dutch Calvinists in the Midwest. Doctoral dissertation, Catholic University of America, Washington, DC.

Dembo, T. (1976). The dynamics of anger. In J. De Rivera (Ed.). Field theory as human science. (pp. 324-422). New York: Gardner Press. (Original work published in 1931.)

Dewey, J. (1938). Democracy and education: An introduction to the philosophy of education. New York: The Macmillian Company.

De Young, A. (1994). Researching rural American schools: Continuing cultural themes and cultural conflicts in the countryside. Lexington, KY: University of Kentucky.

De Young, A. (Ed.). (1991). Rural education: Issues and practices. New York: Garland Publishing, Inc.

Donaldson, G. A., Jr. (1986). Do you need to leave home to grow up? The rural adolescent's dilemma. Research in Rural Education, 3(3), 121-125.

Duncan, O. D. (1961). A socioeconomic index for all occupations and Appendix B. In A. J. Reiss, Jr., O. Duncan, P. K. Hatt, \& C. C. North (Eds.), Occupations and social status. (pp. 109-138, 263-275). New York: The Free Press of Glencoe.

Dunne, F., Elliott, R., \& Carlson, W. S. (1981). Sex differences in the educational and occupational aspirations of rural youth. Journal of Vocational Behavior, 18(1), 56-66.

Elliott, J. (1987). Rural students at risk. Paper presented at the Annual Success for Students AtRisk conference, Chicago, February 4-7, 1987. Iowa City, IA: University of Iowa. (ERIC Document Reproduction Service No. ED 285 708)

Falk, W. W. \& Salter, N. J. (1978). The stability of status orientations among young white, rural women from three southern states. Journal of Vocational Behavior, 12(1), 20-32.

Festinger, L. (1954). A theory of social comparison processes. Human Relations, 7, 117-140.

Frank, J. D. (1935a). Individual differences in certain aspects of the level of aspiration. American Journal of Psychology, 47, 119-128.

Frank J. D. (1935b). Some psychological determinants of the level of aspirations. American Journal of Psychology, 47, 285-293. 
Friedman, J. \& Miller, J. (1965). The urban field. Journal of the American Institute of Planners, $31(11), 312-320$.

Fuguitt, G. V. (1985). The nonmetropolitan turnaround. Annual Review of Sociology 11: 259-280.

Gardiner, J. W. (1940). The relation of certain personality variables to level of aspiration. Journal of Psychology, 9, 191-206.

Gibbs, R. M., Swaim, P. L., \& Teixera, R. (1998). Rural education and the training in the new economy the myth of the rural skills gap. Ames: Iowa State University Press.

Governor's Council on Agricultural Education. (1998). The Grand Plan for Agricultural Education in Iowa. Des Moines: Author.

Haller, E. J., \& Virkler, S. J. (1993). Another look at rural-nonrural differences in students' educational aspirations. Journal of Research in Rural Education, 9(3), 170-178.

Hauenstein, D. A. (1998). A conceptual framework for educational objectives: A holistic approach to traditional taxonomies. New York: University Press of America.

Hektner, J. M. (1995). When moving up implies moving out: Rural adolescent conflict in the transition to adulthood. Journal of Research in Rural Education, 11(1), 3-14.

Honeyman, D., Thompson, E., \& Wood, R. (1989). Financing rural and small schools: Issues of adequacy and equity. Charleston, WV: ERIC Clearinghouse on Rural Education and Small Schools, ERIC/CRESS Accession No. RC 017315.

Hoppe, F. (1976). Success and failure. In J. De Rivera (Ed.), Field theory as human science. (pp. 324-422). New York: Gardner Press. (Original work published in 1931.)

Howell, F. M., Tung, Y. Y., \& Wade-Harper, C. (1996). The social cost of growing-up in rural America: Rural development and social change during the twentieth century. Social Science Research Center, Mississippi State University, Social Research Report Series 96-5.

Howley, C., \& Howley, A. (1995). The power of babble: Technology and rural eduçation. Phi Delta Kappan 77(2), 26-31.

Hurn, C. J. (1993). The limits and possibilities of schooling ( $3^{\text {rd }}$ ed.). Boston: Allyn and Bacon.

Johnson, K. M., \& Beale, C. L. (1995). The rural rebound revisited. American Demographics July: 46-55.

Kaestle, C. F. (1983). Pillars of the republic: Common schools and American Society, 1780-1860. New York: Hill and Wang. 
Khattri, N., Riley, K. W., \& Kane, M. B. (1997). Students at risk in poor rural areas: A review of research. Journal of Research in Rural Education 13(1), 79-100.

Kok, J. H. (1998). Patterns of the western mind: A reformed perspective. Sioux Center, IA: Dordt Press.

Kozol, J. (1984). The night is dark and I am far from home. A political indictment of the U.S. public schools. New York: Continuum Publishing Company.

Lee, O. C. (1984). An investigation of the psychosocial variables in the occupational aspirations and expectations of rural black and white adolescents: Implications for vocational education. Journal of Research and Development in Education, 17,(3), 28-34.

Ley, J., Nelson, S., \& Beltyukova, S. (1996). Congruence of aspirations of rural youth with expectations held by parents ans school staff. Journal of Research in Rural Education, 12(3), 133-141.

Majoribanks, K. (1984). Ethnicity, family, environment and adolescents' aspirations: The Laosa model. Journal of Educational Psychology, 77(3), 166-171.

Marini, M. M., \& Greenberger, E. (1978). Sex differences in educational aspirations and expectations. American Educational Research Journal, 15(1), 67-79.

McClelland, D. C. (1961). The achieving society. Princeton, NJ: Van Nostrand.

McClelland, D.C., Atkinson, J. W., \& Clark, R. A. (1949). The projective expression of needs: The effect of ego-involvement, success, and failure of perception. The Journal of Psychology, 27, 311-330.

McCracken, D. J., Barcinas, J. D. T., \& Wims, D. (1991). High school curriculum and aspirations of students in Ohio and southwest Georgia. In Ohio Agricultural Research Development Center, School and Community Influences on Occupational and Educational Plans of Rural Youth.

McCracken, D. J., \& Odell, K. S. (1988). Career aspirations of rural secondary students. Journal of Vocational and Technical Education, 5(1), 3-12, Fall 1988.

McDermott, M. D. (1997). Educational experiences and academic achievement of rural students as compared to suburban and urban students in the United States. Doctoral dissertation, Iowa State University, Ames, IA.

McNair, D., \& Brown, D. (1983). Predicting the occupational aspirations, occupational expectations, and career maturity of black and white male and female $10^{\text {th }}$ graders. The Vocational Guidance Quarterly, 32(1), 29-36.

Miller, W. W. (1995). Where there is a will, there is a way. The Agricultural Education Magazine, 67(12), 7-11. 
Murray, H. A. (1938). Explorations in personality. New York: Oxford University Press.

Nachtigal, P. (Ed.). (1982). Rural education: In search of a better way. Boulder, CO: Westview.

National Center for Educational Statistics. (1995). U.S. Department of Education, Office of Educational Research and Improvement. http://nces.ed.gov/pubs.

National Center for Educational Statistics. (1998). Digest of Educational Statistics. U.S. Department of Education, NCES Electronic Catalog. http://nces.ed.gov/pubsearch/ pubsinfo.asp.pubid $=199903 \mathrm{~b}$.

National Council for Agricuitural Education. (1999). A new era in agriculture. http://www.teamaged.org/2020/home.htm.

New International Websters Comprehensive Dictionary of the English Language, Encyclopedic Edition. (1996). Naples, FL: Trident Press International.

O'Dell, K. S. (1986). Educational and occupational aspirations and expectations of rural Ohio tenth- and twelfth-grade students. Doctoral dissertation, Ohio State University, Columbus, $\mathrm{OH}$.

Ohlendorf, G. W., \& Rafferty, D. M. (1982). The educational and occupational aspiration of Louisiana rural high school students: A comparative study (Bulletin No. 737). Baton Rouge, LA: Louisiana State University, Agricultural Experiment Station, Center for Agricultural Sciences and Rural Development. (ERIC Document Reproduction Service No. ED 218 020)

Pelavin Research Institute. (1996). Proceedings of the rural education issues meeting. Washington, DC: Author.

Peshkin, A. (1982). The imperfect union. Chicago: University of Chicago Press.

Powers, B. C. (1974). The relationship of occupational aspirations and expectations to selected personal, family, community, and school related factors. Dissertation Abstracts International, 35, 2137A. (University Microfilms No. 74-21,075)

Quaglia, R. J. (1998). Impacting student aspirations: Eight conditions that make a difference. Submitted to Educational Leadership.

Quaglia, R. J., \& Cobb, C. D. (1996). Toward a theory of student aspirations. Journal of Research in Rural Education, 12(3), 127-132.

Reid, J. N. (1989). The rural economy and rural youth: Challenges for the future. Research in Rural Education, 6, 17-24.

Rogers, E. M., Burdge, R. J., Korsching, P. F., \& Donnermeyer, J. F. (1988). Social changes in rural societies ( $3^{\text {rd }}$ ed.). Englewood Cliffs, NJ: Prentice-Hall. 
Rosenfield, S. A. \& Sher, J. P. (1977). Urbanization of rural schools, 1840-1970, in Education in Rural America: A Reassessment of Conventional Wisdom (ed. by Jonathan Sher). Boulder, CO: Westview.

Schonert-Reichl, K. A., Elliott, J. P., \& Bills, D. B. (1993). The effects of rural schools and communities on adult adjustment: $A$ ten year follow-up of rural Iowa youth. Vancouver, BC: Department of Educational Psychology and Special Education, University of British Columbia.

Sewell, W. H., \& Hauser, R. M. (1976). Causes and consequences of higher education: Modes of status attainment process. In W. H. Sewell, R. M. Hauser, \& D. L. Featherman (Eds.), Schooling and achievement in American society. (pp. 9-28). New York: Academic Press.

Sher, J. P. \& Tompkins, R. B. (1977). Economy, efficiency, and equality: The myths of rural school and district consolidation. In J. Sher (Ed.), Education in rural America: $A$ reassessment of conventional wisdom. Boulder, CO: Westview.

Sherman, A. (1992). Falling by the wayside: Children in rural America. Washington, DC: Children's Defense Fund.

Snyder, T., Hoffman, C., \& Geddes, C. (1996). Digest of educational statistics 1996 (NCES 96133). Washington, DC: National Center for Educational Statistics.

Stern, J. (1994). The condition in rural schools. U.S. Department of Education, Washington, DC.

Theobald, P., \& Nachtigal, P. (1995). Culture, community, and the promise of rural education. Phi Delta Kappan 77(2), 132-135.

Thompkins, R., \& Deloney, P. (1994). Rural students at risk in Arkansas, Louisiana, New Mexico, Oklahoma, and Texas. Austin, TX: Southwest Educational Development Laboratory.

Tyack, D. B. (1974). The one best system: $A$ history of urban education. Cambridge, MA: Harvard University Press.

United States Bureau of Census. (1998). Populations Estimates Program, Population Division, Washington, DC. http://www.census.gov/population/estimates/county/co-98-1/98c1_19txt.

United States Department of Agriculture. (1992). Agriculture Census, 1992.

Walberg, H. J. (1989). Student aspirations; national and international perspectives. Research in Rural Education, 6(2), 1-6. 